Historic, Archive Document

Do not assume content reflects current scientific knowledge, policies, or practices. 


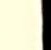



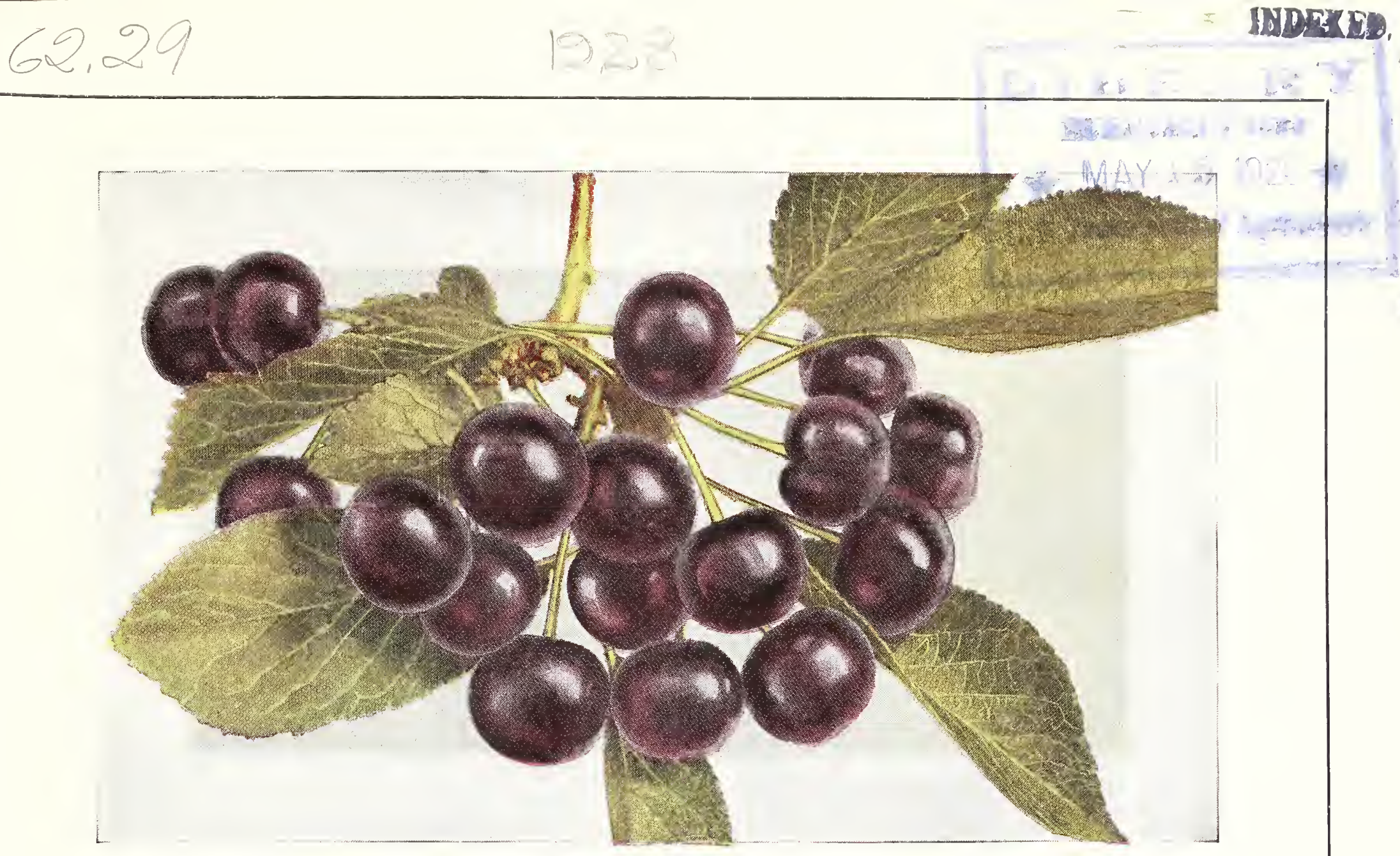

CHERRIES - NO YARD IS TOO SMALL FOR A FEW TREES See Page 11

\section{YEAR BOOK}

\section{The Winfield Nurseries}

Owned and Operated by

\section{Thos. Rogers \& Sons WINFIELD, KANSAS}

Our office building, where you are welcome. Come and see us when in Winfield 


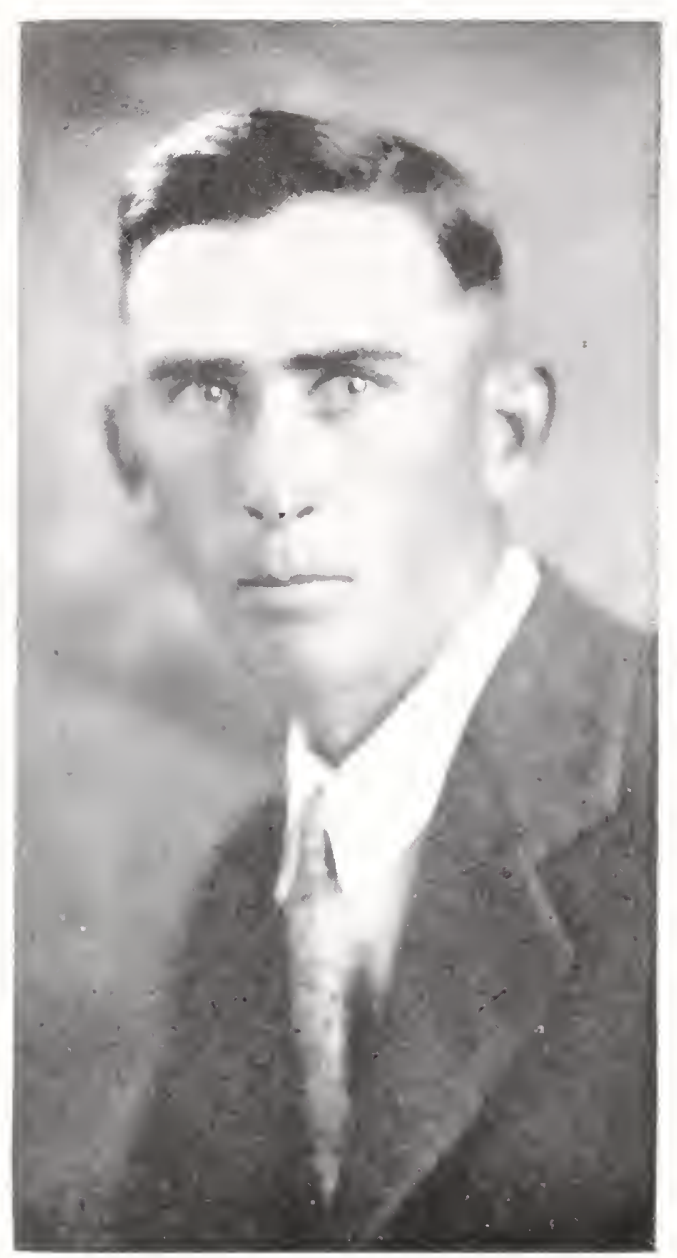

Thos. G. Rogers

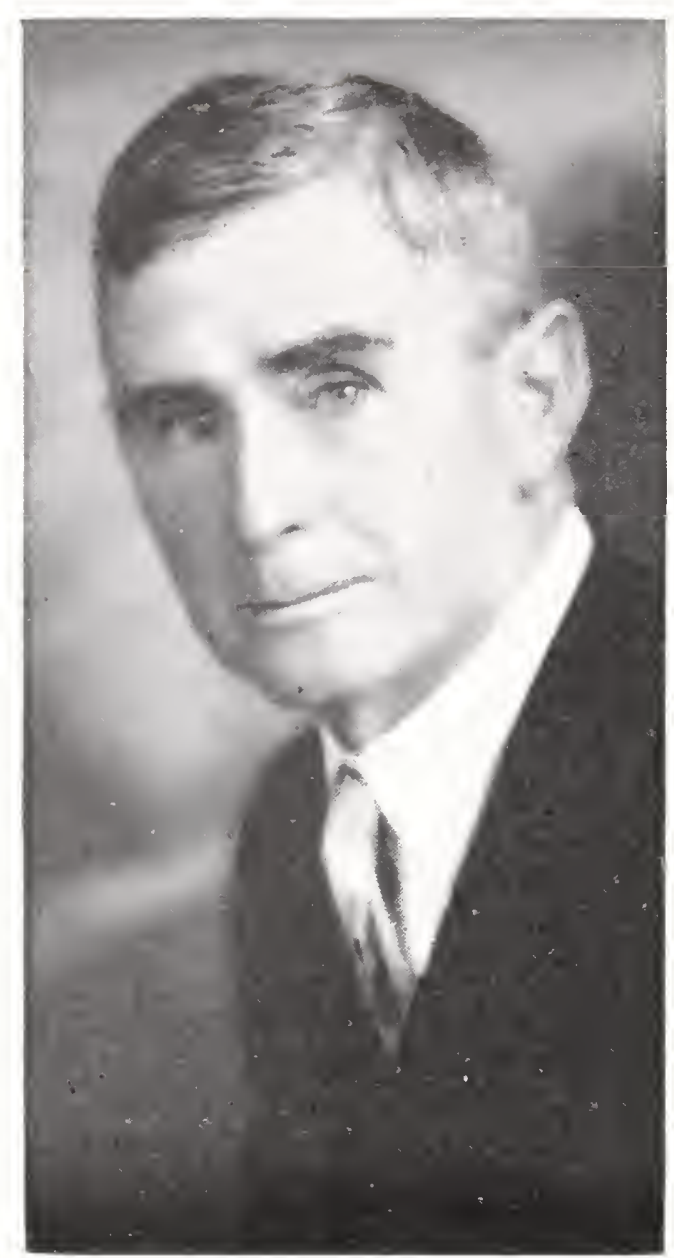

Tom Rogers

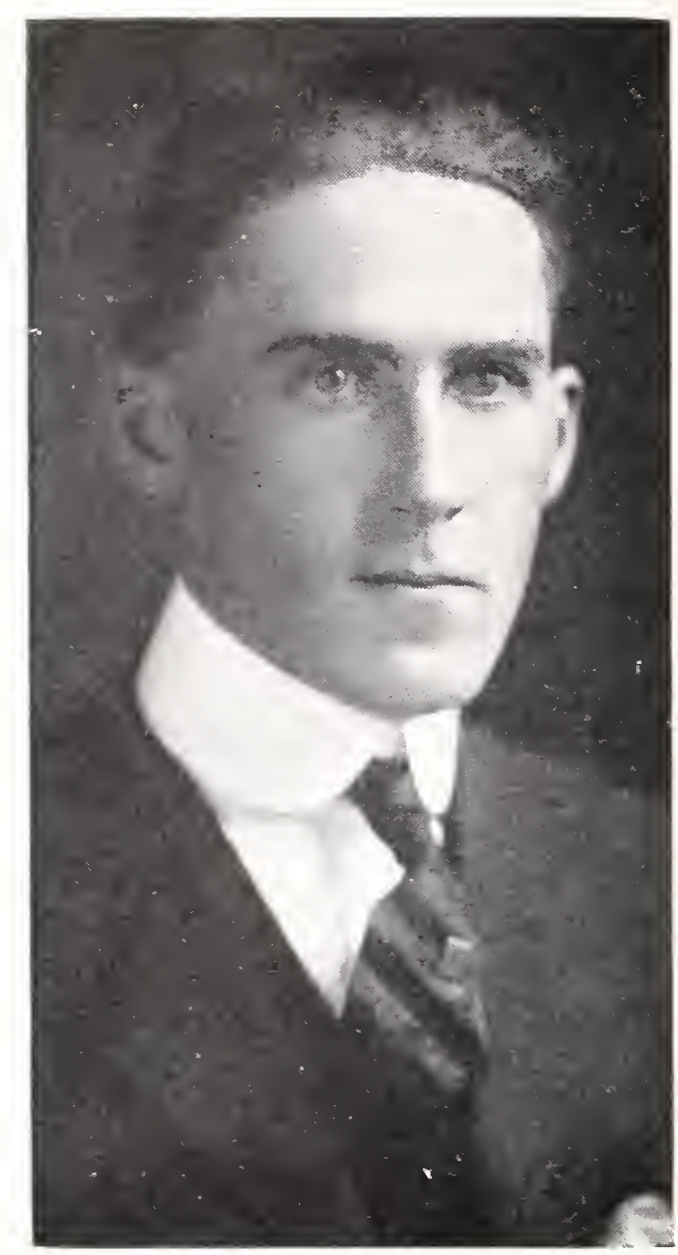

John T. Rogers

\section{A Word About Ourselves}

JOHN T. ROGERS: Landscape architect and designer. Before the war was connected with the Horticultural I) epartment of the Chilocco Indian School and after leaving the army was employed as a landscape architect by the I.oyal Order of Moose at their large school at Mooseheart, Illinois. After gaining much practical experience at Mooseheart, Chicago, and other eastern points, we induced him to remain at home with us, in complete charge of our Landscape Service Department.

TOM ROGERS: Started working in the nurseries at Bloomington, Illinois, as a boy at the age of 12. Later came south to Kansas and at the age of 19 was the field superintendent of the largest nursery in southern Kansas at that time. Has spent the past 40 years as a nurseryman in Wellington and Winfield, growing, propagating and leveloping nursery stock for you, your father, your grandfather, and, we hope for future generations to come. Mr. Rogers personally supervises the packing and shipping rooms, seeing that your order is filled with the same select stock as that which he would plant in his own yard; takes care of the office work, especially the correspondence, as he personally reads and answers the hundreds of letters which we handle daily. During the growing season he is in our nursery fields every clay seeing that the stock for your future orders is receiving the best of care and attention. In fact, he is our general manager, our watchdog and our guardian, even editing and writing this catalogue-his message to you - to see that no unintentional extravagant or misleading statements were made and only honest and true facts were given you. He is "Tom" to all his friends. So, when mailing us your order, say "Dear Tom: Here is my order. Ship it to me at the proper time and see that I get good stock."

Tom is unbecomingly modest, so we had the printer slip the above in the catalogue at the last moment, as it was ready for the press.

THOS. G. ROGERS. Been practically raised in our nursery fields. Started working wlen a boy during school vacations tying buds and since that time has gradually been advancing until he now is our Field Superintenclent with complete charge of our field and propagation work. His practical knowledge and experience is your arlvantage and gain, as he has made possible the extra select and hardy stock which we are using to fill your order.

\section{Foreword}

That we might show our customers the IIinfield Nurseries, that parent garden of the flowering and fruiting stock that is being sent out uncler our labels, has often been our wish. Such a trip being impractical to most of you, we are doing the next best thing, presenting you with our Catalogue of Fruits and Flowers-bring the Vinfield Vurscries to you, within your grasp, your range of vision-and in this crude way point out to you the untold possibilitics and leauty that ma loc derived from Rogers' trees and plants.

We offer you sound, héalthy stock, potential in bloom and fruitage, and by reason of special training and long experience we can aid you $\mathrm{in}$ your choice. Yours, however, is the privilege of selecting, planting, caring and storing up that most delightful and responsible of vocations. Order abundantly today with thought for future needs, that you ancl yours ma harvest with both pleasure and profit. V'ery sincerely,

Thos. Rogers \& Sons

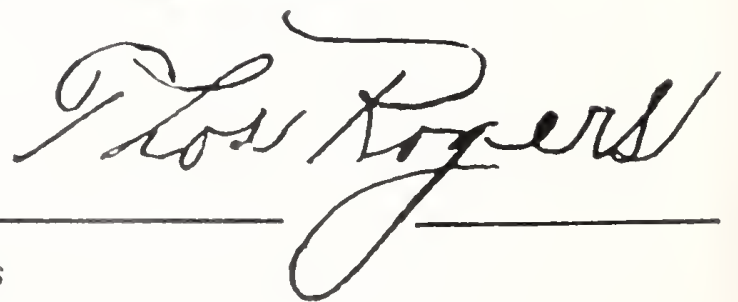




\section{For Your Information}

As we invite your orders for the trees and plants we illustrate and describe, you may ask-and surely you are entitled to know-who we are, and what our business record is; how we have served other buyers and why we know we can serve you to your satisfaction and profit. The facts below are to give you that information.

\section{Well Established}

The Winfield Nurseries were founded over forty years ago. When children at school, you will remember reading in your histories and geographies that "Winfield is noted for its stone quarries and nurseries." The present personnel has had charge for about ten years. For that period while growing, selling and improving the standard of our products, we have also been training men in every department of this highly specialized work. Once a group of pioneers, we are now an organization of experts. It is not uncommon to hear of some nurseries that have been in the same family for generations. Ours is no exception. The personnel of our organization started working in the nursery as boys, as have also most of our present employees.

\section{One Hundred and Fifty Acres in Nurseries}

Our growth has been gradual, but steady, to meet both in quality and kind, the increased demand of buyers. Our big plantings in the Arkansas River Valley in Southern Kansas, favored by fertile soil, are also disciplined by climate that produce the best and hardiest trees and plants, thrifty and full of vitality.

\section{Packing, Shipping and Storage Facilities}

Our packing, storage and shipping facilities have kept pace with the growth of the business. We have one of the most modern equipped packing and storage nursery plants in the middle west. This assures you that your order will reach you in good, fresh condition. Our whole output is handled under cover at all seasons of the year-a part of our progressive methods that guarantee the freshness, grade and quality of our stock. We have ample shipping facilities out of Winfield. The Santa Fe, Southern Kansas, Frisco, and Missouri Pacific railroads running several trains daily in all directions. The American Express Company carries express over all lines.

\section{What We Agree To Do}

We take all risks of transportation and guarantee the delivery of stock in good order. If not in first-class condition on arrival notify us and we will immediately forward new stock to take its place under the same guarantee. Should any plant die during the first season after planting, having had good care under a normal growing season, we will replace same at one-half the purchase price.

Non-Warranty-In the event that any stock sold by us should prove untrue to name under which it is sold, we hereby agree on proper proof of such untrueness to name to replace that portion of the order proven untrue to name or to refund twice the purchase price thereof. Except for such liability, and in respect to all nursery stock sold by us, we give no warranty, express or implied, as to description, productiveness, or any other matter.

\section{Co-operative Buying}

THOS. ROGERS \& SONS.

If you will get your friends and neighbors to order with you and the total number of trees amounts to 100 (or 500 ), each one of you will be entitled to the 100 (or 500) rate on each kind or variety.

Send in their names. We will send a new Catalog and order-blank to each one, and tell them it is at your suggestion.

Let each one fill out his individual order-with our advice if desired; then you can send them in with your order.

These orders will be put up in separate packages; they will then be shipped all together in one packing-case to anyone you wish for distribution, which will effect a saving to each one of you on transportation charges, or they can be shipped to each buyer separately.

\section{Transportation Charges}

We prepay transportation charges on all orders a mounting to $\$ 25.00$ or more.

\section{Remittance}

Should be made by postal or express money order, bank draft, or we will take your personal check if you prefer. Do not send currency, as it is unsafe.

\section{Reference}

As to our financial responsibilities we refer you to the First National Bank or any business house of this city. As to fair dealings and trustworthiness we offer you any of your friends who may have purchased stock of us heretofore. Your neighbor may be one of our customers. Ask him.

\section{Stock Healthy and Free From Pest and Disease}

State Inspectors examine our stock of trees regularly and thoroughly and every shipment that goes out bears an official certificate of inspection.

Office of the State Entomologist. University of Kansas. No. A 1549. Lawrence, June 24, 1927. CERTIFICATE OF NURSERY INSPECTION-This is to certify that in accordance with Section 2-703 of the General Statutes of 1923 the nursery stock now growing for sale by Winfield Nurseries (Thos. Rogers \& Sons) of Winfield, Kansas, has been inspected by a duly authorized inspector, and found apparently free from dangerously injurious insects or plant diseases.

Invalid after June 1, 1928.

H. B. HUNGERFORD, State Entomologist. 


\section{Apples}

The first fruit in importance is the apple. As an article of food it is unsurpassed. As a dessert fruit it is unequalled. Whoever thought of pie without having a good old juicy apple pie in mind? For family use there is no fruit that is more indispensable; no fruit so healthy. With the average price on the market steadily increasing and the immense demand for local and foreign consumption, there should be no question in your mind as to the assured profits of an apple orchard. Your home orchard should contain both "cooking" and "eating" varieties. By making a judicious selection a constant succession of fresh apples may be had from early summer till spring. While a moderate home orchard will supply an abundance, you need not fear of having an over-supply of this delicious fruit. Your neighbors will see to that, gratefully paying you your requested price.

The apple grows best in a deep. rich soil, such as would produce good corn or potatoes. Almost any soil that is not wet can be used for an orchard. Preparation of soil consists mainly in deep, thorough plowing, harrowing, and leveling. Plant the trees from 20 to 30 feet apart, preferably 30 feet. The distance apart depends to some extent upon the kind of soil and also the variety of apple planted.

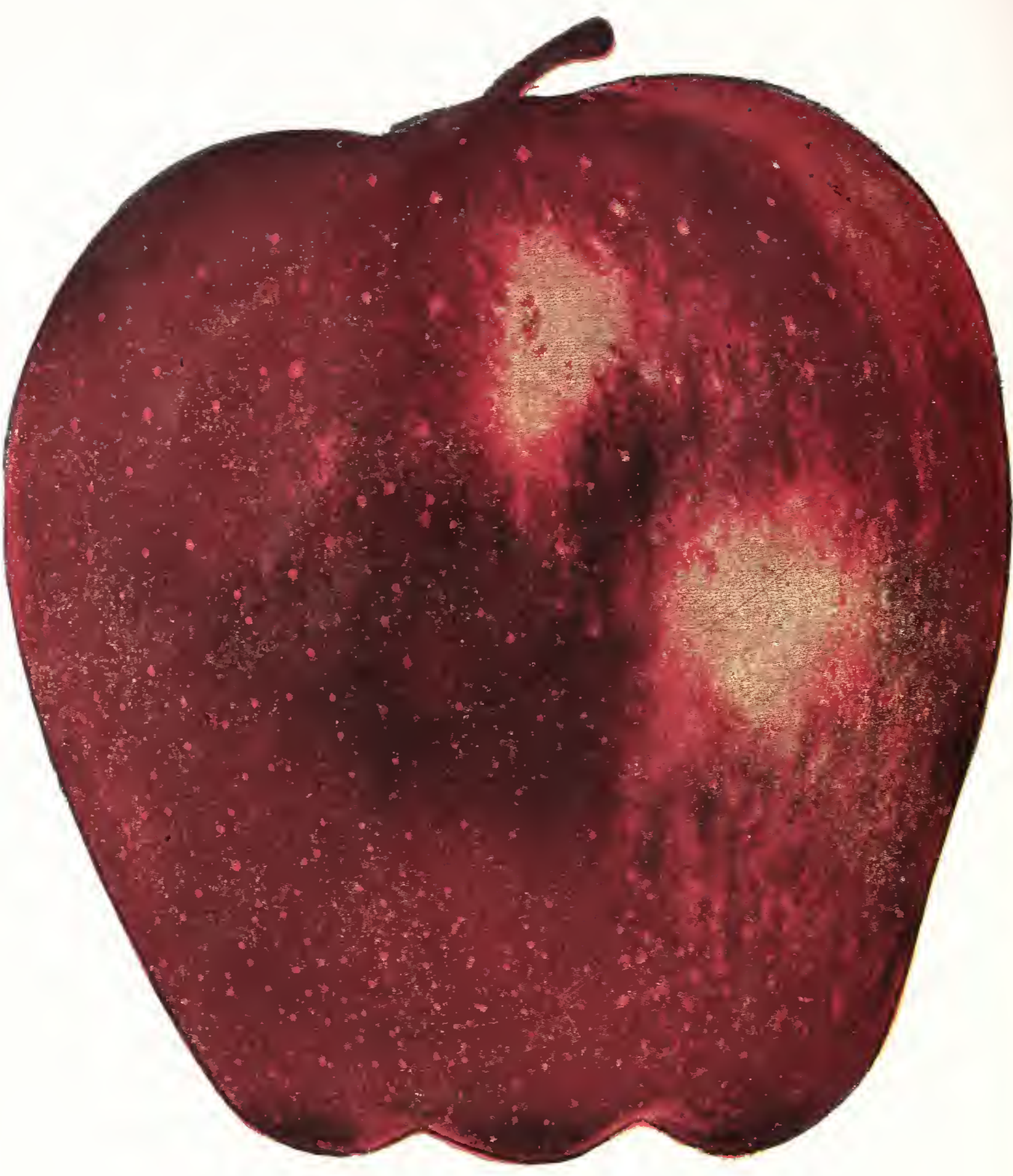

The Delicious Apple-Propagated best by the Winfield Nurseries

The pay personal attention to the selection of our scions and buds for our apple trees. Our buds are selected from hardy, thrifty bearing apple trees that have been producing gocd crops annually. In this way we not only are certain that our varieties are true to name, but we also know that they will produce unusually good crops of fruit of high quality. Our method insures you more vigorous trees, that will bear younger a nd produce better crops than under any other method of propagation. You should not overlook this feature as the propagation of the trees for your future orchard is of the utmost importance to you. It costs us a great deal more, but it is economy and a saving to you. You have the assurance of buying good, clean, healthy trees of purebred known parentage if you buy Rogers stock. Our apple trees are budded on whole roots. The trees are well rooted, straight a nd smooth, and run to perfect tops.

\section{Summer V'arieties}

YELLOW TRANSPARENT -By far the best of the early summer apples for home or commercial purposes. Its fruit is somewhat more conical than Early Harvest, more yellow and better flavor. The color is a clear, bright yellow when fully ripe, but the fruit is fit for use long before they reach full maturity, and usually are sent to market when the seeds have reached full size but before they have begun to turn brown. Because of the upright habit of the tree, it is preferted as a filler in commercial orchards, and as the trees come into bearing very young it enables the commercial planter to realize a profit from his orchard before the permanent varieties come into bearing. IVe recommend this variety.

LIVELAND RASPBERRY - One of the handsomest of summer apples and among the best in quality. Skin clear, waxen-white, striped and mottled with crimson. Flesh snow-white, often tinged with pink next the skin and of snappy, pleasing flavor. Frequently bears when there are no other apples, as it blooms late. Tree a moderate size, productive and resistant to many troublesome diseases. Excellent for home use or as a filler in commercial orchards.

RED JUNE-Among strictly summer apples the Red June is one of the best varieties. While the tree is not a strong grower, yet it is healthy, hardy and thrifty. This variety usually bears fruit at four years after planting and produces good crops regularly. Its deep red color, excellent quality, and good bearing ability make it a favorite. Ripens in early July.

EARLY HARVEST -This apple, along with Yellow Transparent, is one of the best of early apples. It is excellent for eating or cooking. It is of medium size, round, and yellowish-white in color.

SWEET JUNE - Inother excellent early apple. The tree is an upright and sprearling grower and bears abundantly. The fruit is of good size, round, flesh is yellow. The fruit is sweet and rich and keeps good. 


\section{Summer Apples - Continued}

COOPER'S EARLY WHITE--The one early variety in southern Kansas and northern Oklahoma which should be in every one of our apple tree orders. It bears at a young age, has a good crop every year, a nd the fruit is excellent. The tree is vigorous but of dwarfy habits. The fruit is of good size, light yellow in color. The flesh is white, subacid. Ripens during the latter part of July or first of August. If you live in town and want one or two apple trees, plant our Cooper's Early White.

DUCHESS OF OLDENBURG-An attractive yellow apple, almost covered with red stripes. The flesh is juicy and tender. As the tree is only a moderate grower it can be planted close and in commercial orchards is often used as a filler. Bearing heavy crops at a young age, and being such a good market variety, this tree should be planted in large numbers.

\section{Autumn Varieties}

MAIDEN BLUSH-Large flat, pale yellow, with slight crimson blush when exposed to sun; flesh white, tender, strong sub-acid; stands at head of apples for frying; good market variety. August and September.

PENNSYLVANIA RED STREAK-An old-time favorite, but has been discarded by many growers. Locally there is a heavy demand for this variety and grow it in large numbers. The tree is vigorous and bears well. The fruit is flat, streaked with dull red. Closely resembles the old Rambo, but better suited for this climate. Fine for eating and a good cooker. Our local commercial orchardists state the demand for this apple far exceeds their usual supply.

WEALTHY - The leading variety of its season. It ripens in mid-September and is suitable for use as late as Christmas. The fruit ranges quite uniform in size, being about that of the Jonathan. In color it is light yellow, so heavily streaked with red as to appear much more red than yellow. Its flesh is white, somewhat tinged with pink, and is fine-grained, very juicy and of excellent flavor. The trees come into bearing early and are fine producers. Tris variety has so many good qualities that it has become one of the leading commercial varieties.

GRIMES GOLDEN-This is the best early winter apple. It is of bright golden-yellow color, uniform medium size, and possessed of a texture and flavor that is pleasing to every palate. Grimes Golden is the best kind of an eating apple, and for pies there are few that are better. You have never eaten a good apple pie until you have eaten one made from our Grimes Golden. This variety is very excellent for the commercial orchard. It produces regularly and ships well, bringing high prices. It is the best yellow apple of its season.

JONATHAN_-The bright, cheerful color and waxy skin of this apple make it of most attractive appearance. Its juicy, snappy flavor makes it appeal to the palate. It is the one apple that never disappoints. Jonathan is ready to use just after it begins to color in late summer, and may be held in storage until the middle of the next summer. It is one of the finest of apples for the home orchard and among the leaders for commercial purposes. Jonathan thrives everywhere throughout the Middle West and should be included in every order.

WINTER BANANA-The Winter Banana is not a winter variety, as the name implies, but ripens in the fall. The tree is a fine, vigorous grower and has large, healthy foliage. The tree is an early bearer of gcod crops. The fruit is medium to large, smooth and handsome, golden-yellow, usually shaded with red blush; flesh fine-grained, rich sub-acid; of the highest quality and is a good dessert apple. A valuable market variety, as it is a good keeper.

KING DAVID - Very productive, bearing good crops year after year. This variety is similar to Jonathan, but more tart. The tree is a hardy, vigorous grower, coming into bearing about the fourth or fifth year. Often used as a filler. The fruit is of medium size, very dark rich red, almost a purplish-black on the sunny side.

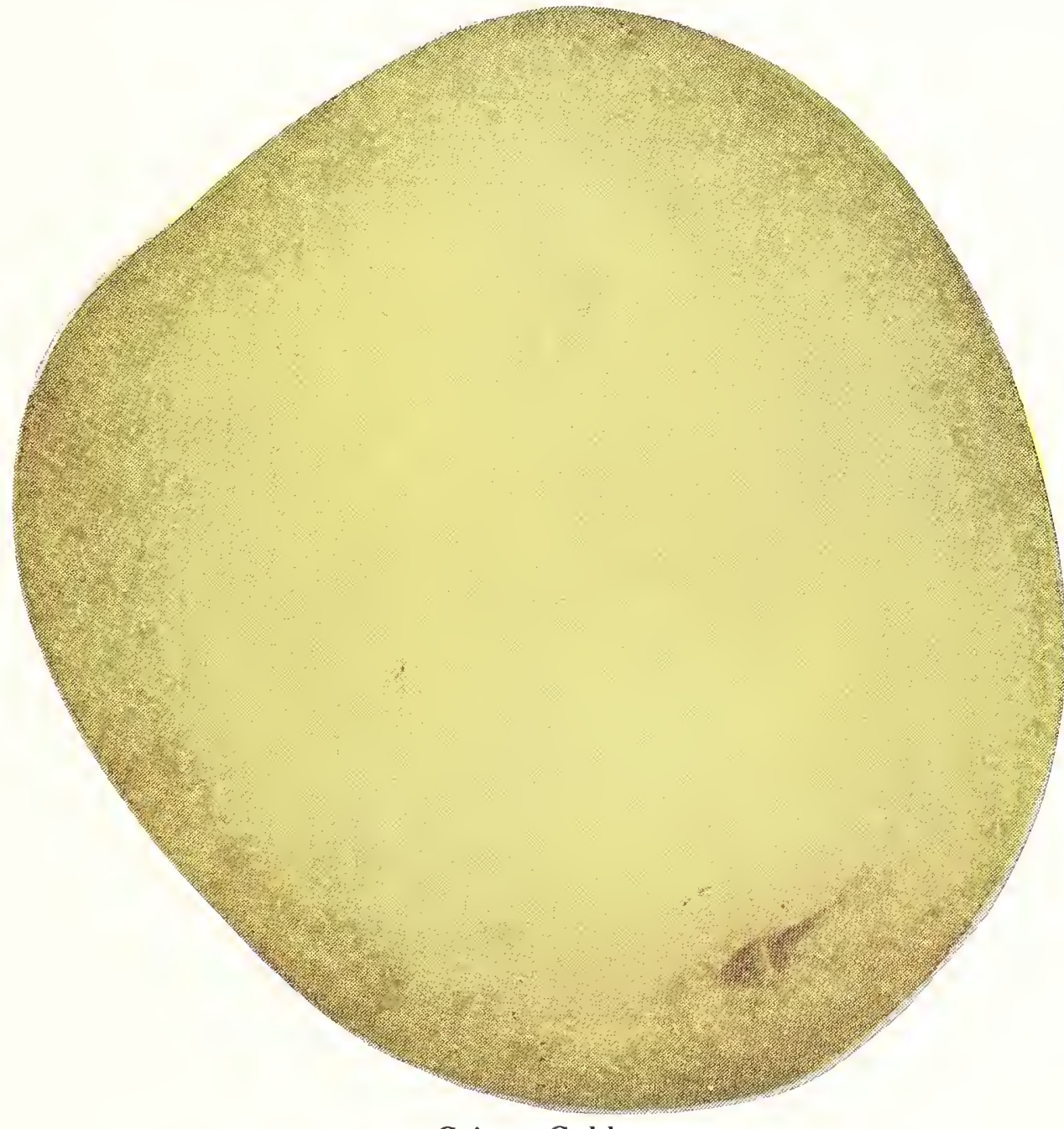

Winter Varieties

ROME BEAUTY - Of the large, round, red apples this is one of the best. The fruit is of handsome appearance and runs well to large sizes. The flesh is firm, moderately fine-grained, juicy, mild, pleasant flavor, and excellent for eating. The tree is of erect habit and produces heavily. As a market fruit, Rome Beauty is very popular, and for home use it has few superiors.

BEN DAVIS-- Striped red, large and attractive. Sure bearer. The tree is healthy and vigorous and should be planted as a "catch" in every orchard. Its greatest fault is the lack of quality.

MISSOURI PIPPIN-The tree bears young, regularly, and too heavy. The tree is usually short-lived on account of overbearing. The fruit is of good size, and large, if thinned. Flesh white, juicy, quality only fair; light ground, covered with bright red stripes, often quite dark. This variety is ideal as a filler in commercial orchards.

Grimes Golden 


\section{Winter Apples \\ - Continued}

WINESAP - One of the oldest and most popular apples, being a good shipper and an exceptionally good keeper in ordinary cold storage. Well-grown Winesaps command a premium over most other winter apples with commercial buyers. Splendid bright red. Flesh is tinged with yellow; very firm, juicy, and of the best quality. A favorite with everyone. The tree is a vigorous, spreading open grower. Hardy, adapted to planting in every part of the country except in the northern states. Over $\mathrm{SO}^{\mathrm{r}}$, of the commercial orchards in southern Kansas and northern Oklahoma are planted to Winesap. What other good word for old Winesap is necessary.

MAMMOTH BLACK TWIG - This has often been confused with Paragon. Many nursery catalogues list the description of Paragon as being that of Mammoth Black Twig. The Mammoth Black Twig is a large apple of good quality and is an excellent keeper. Has been planted extensively. but not at present, because it is a shy bearer. Newer and better varieties are overshadowing it.

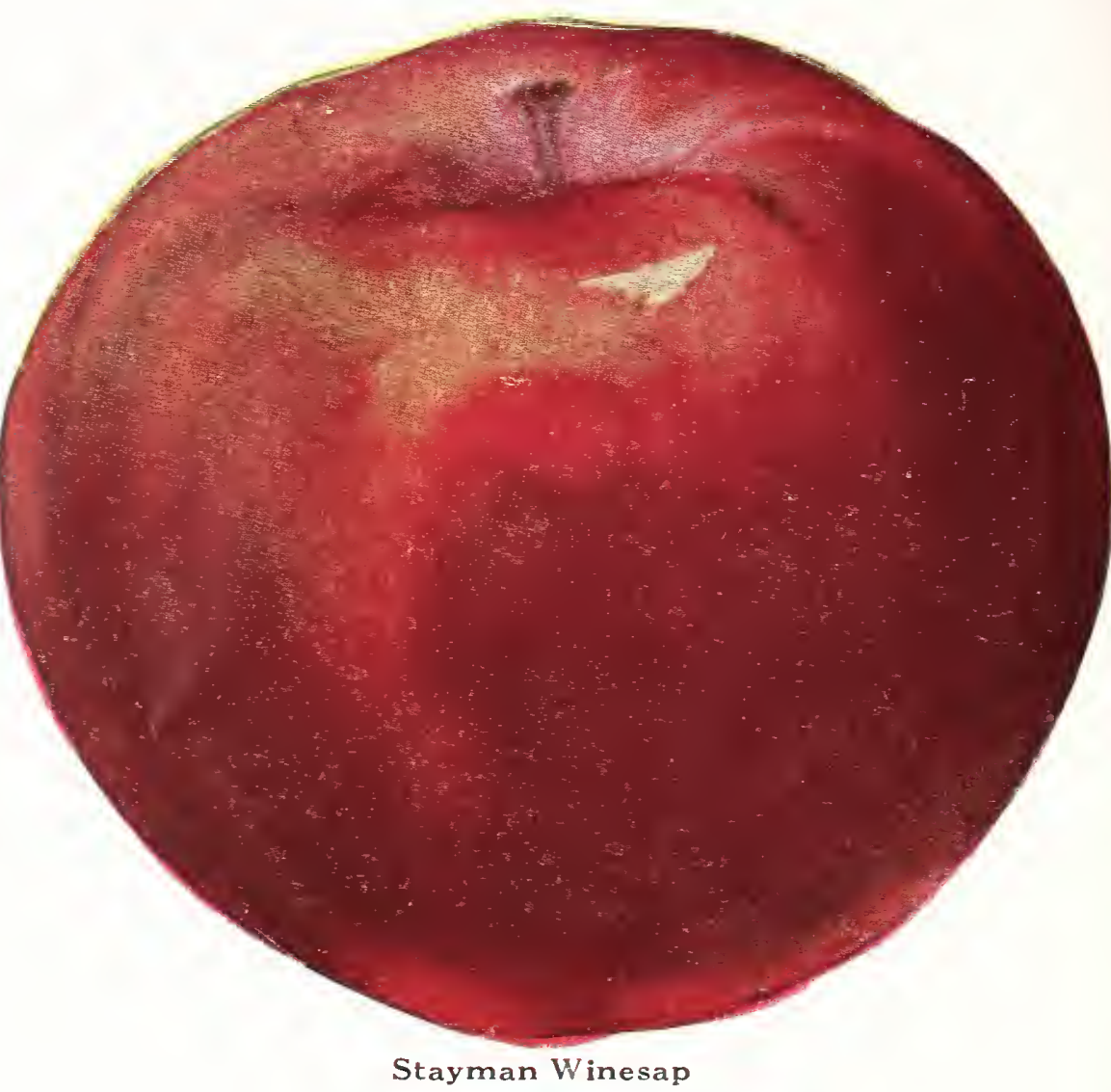

STAYMAN WINESAP_Of the several important descendants of Winesap, this variety is leaping into prominence as a splendid sort for the home or commercial orchard. The tree is a sturdy grower and a very heavy producer. It is a dapted to a wide range of soils and climates, thriving almost wherever planted. It runs to large sizes. The fruit is of deep red color, with firm flesh, tender, juicy, and the same rich flavor of the parent. IIe recommend this variety for the home or commercial orchard.

PARAGON WINESAP - In many instances the Paragon has been planted under the name of the Mammoth Black Twig, giving the latter an undeserved reputation. And, on the other hand, Mammoth Black Twig has been planted for Paragon. Our Paragon is true and genuine. Our Paragon has the good qualities of the Stayman IIinesap. The fruit is large and dark red like the old Vinesap. The tree is vigorous and an open grower.

YORK IMPERIAL-For Niddle Western conditions this is an important commercial apple, always finding a ready market and good prices. The fruit is of irregular shape, lop-sided or oblique. The skin is heavily mottled with light red; flesh firm, fine-grained and juicy. In productiveness, this apple is one of the best, yielding crops with regularity.

GANO - Very similar to Ben Davis, of a little better color and quality. A commercial sort locally.

ARKANSAS BLACK - A remarkably handsome, large, smooth apple. Roundish-flat to conical in shape. Color a very dark red, slightly dotted with white. Flesh is yellow, juicy and delicious, keeping late. The tree is a vigorous, upright grower. It is a shy bearer.

RAWL JANET - The tree is a good grower but not overly large. The fruit is of medium size and has mixed and striped crimson on yellow and green. The flavor is mild and refreshing. Popular as a home fruit.

McINTOSH RED - Of good size and attractive appearance, bright deep red. Flesh is very tender. Especially popular as a western commercial variety.

GOLDEN WINESAP - The Golden Ninesap is a handsome yellow winter apple and is a strong rival of the Grimes Golden, being much larger and hardier. Many of our northern customers consider it even better. It is a wonderful new apple-great in size, great in quality and flavor, and in its long-keeping ability. The fruit resembles the Winter Banana apple considerably in color and shape, though the Golden ITinesap is quite a little larger. The rich, golden-yellow color when well ripened, is blushed with red, making it an extremely attractive apple for market. One of the best, longest keepers of all the apples, being firm and solid when practically all other varieties are gone. The flavor of the Crolden IIinesap is delicious, having the goodness of the old-fashioned Bellflower. We have an extra fine stock of Golden Winesap trees to offer vou this season and if vou are planting apple trees, write this variety in your order at once.

DELICIOUS - It is delicious in every sense of the word. The fruit is large, rather elongated, and with its rich crimson coloring and extraordinary flavor it commands the highest prices in the apple market and is a favorite everywhere. It is known and easily distinguished by the five little knobs on the blossom end which are often light yellow, blending perfectly with its crimson beauty. It is productive after it comes into bearing, the tree is of free open growth, and very hardy. It is a good keeper and shipper. Considered the peer of the apple production during the past twenty vears.

\section{Crab Apples}

FLORENCE - A crab larger than the Transcendent. The quality is excellent. The tree is thrifty and las been thoroughly tried in this section and found to be better than all other crabs.

WHITNEY - I popular crab apple of good size. Fruit is attractive rellow, striped with red. Ouality rery good. A thrifty, upright grower. Hardy everywhere.

TRANSCENDENT-Fruit is medium to large, round, vellowish-red cheek or almost solid red. Very fine for all purposes. Quality is excellent. The tree is a strong grower.

HYSLOP-The fruit is large, brilliant, dark red, of fair quality. The tree is a strong grower. Fruit is excellent for jelly and preserves. 


\section{Pears}

You can pick out a beautiful and profitable Pear, as all that we list are good in this respect. Also, every variety yields a fruit so delicious that its place belongs on the table, as a dessert fruit. The home orchard is not complete without pears and they are a very profitable commercial crop in nearly all parts of the country. The quality of the pear is much improved by picking before maturity and by proper ripening indoors.

DOUGLASS - The Douglass comes into bearing at an early age and is resistant to blight. It is golden-yellow in color. The flesh is white, tender and juicy. Far surpasses all other pears in flavor. Very productive.

KIEFFER-One of the most popular market pears grown. The tree is a vigorous and beautiful upright grower, bears young and heavily, and is almost exempt from blight. The fruit is of good size, rich color and fair quality. The fruit should be picked at maturity and ripened indoors.

CLAPP'S FAVORITE-A fine large pear closely resembling the Bartlett. It is lemon-yellow in color with brown dots. It is the equal of the Bartlett in flavor. Ripens during the latter part of August.

BARTLETT-The fruit is large, yellow, with a beautiful blush. It is very juicy with a rich musky flavor. The tree is a vigorous erect grower and is excellent for the home or commercial orchard. It is an early bearer. Ripens the last of August or first of September.

SECKEL - The Seckel is often called the little sugar pear. The fruit is small, yellow and overspread with a brownish shade. The flesh is juicy, sweet and spicy. The tree is thrifty, large, and of a spreading growth, bears heavy crops regularly and seldom ever blights. August 15 th to September 20 th.

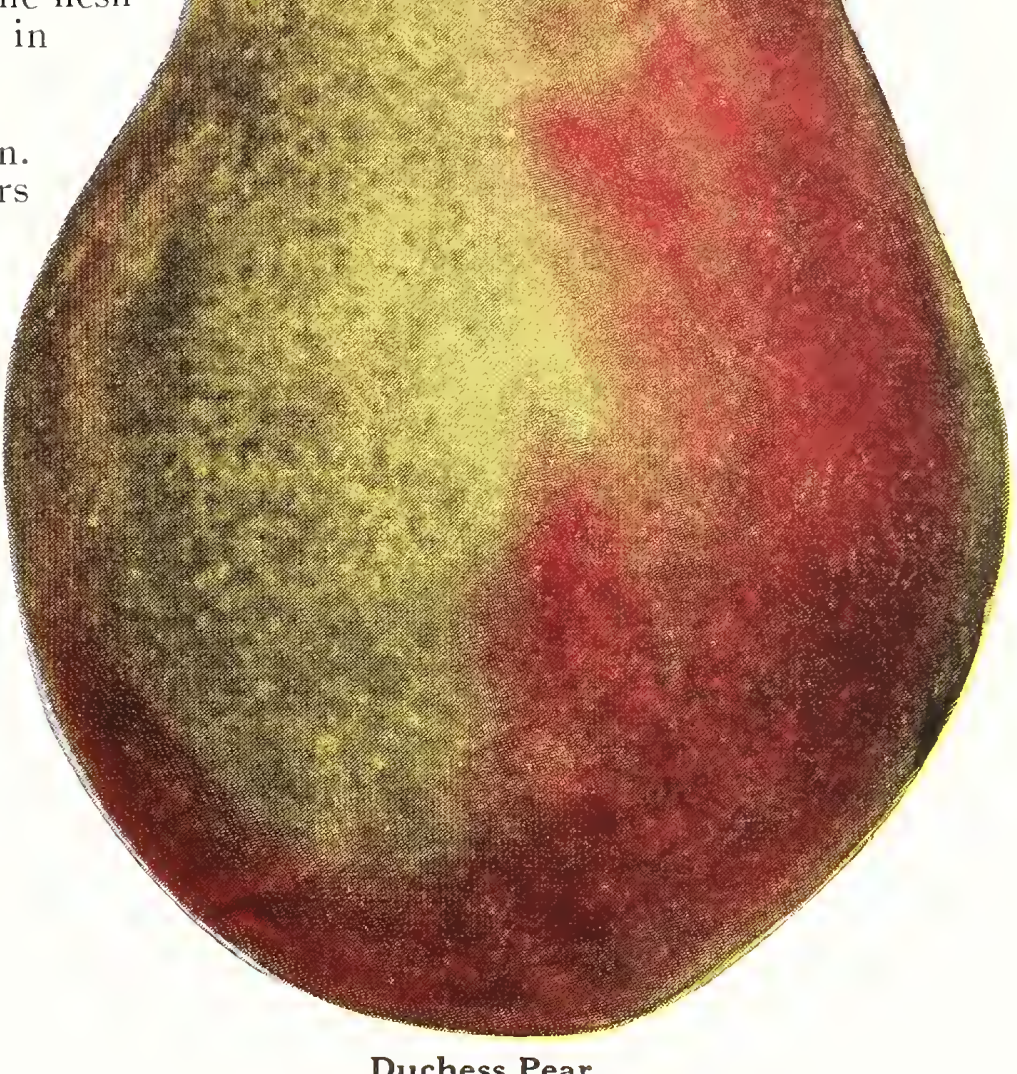

GARBER - The tree is thrifty and bears young. It is almost blight-proof. The fruit ripens the last of September and sells readily on the market. It is of medium size, yellow and well colored with red.

BUERRE D'ANJOU-A large fine pear, being greenish-yellow in color and with slightly red cheek when exposed to the sun. It is of very excellent flavor, sweet and rich. The tree is a strong grower, bears early and abundantly. September to December.

DUCHESS (d'Angoulome)-A large showy pear, often weighing one pound each; greenish-yellow, rough, uneven surface. We consider the Duchess to be the most profitable dwarf pear in this section. The trees rarely ever blight and are always loaded down with fruit. We have seen the little trees in the nursery row hang full of fruit. It does its best as a dwarf. Ripens in September and October.

\section{Apricots}

A beautiful and delicious fruit; a close relative of the plum and peach, combining the qualities of both. The fruit ripens after the early cherries and just before the plums and peaches. The tree is as hardy as the peach and requires about the same cultivation. The fruit ships well and commands a good price in the markets but if you have any surplus fruit to sell you will find a good local demand for it. Apricots should be set about 15 feet apart each way and need the same management as peach trees.

EDRINGTON_This variety originated some years ago at Belle Plaine, Kansas, and is being propagated exclusively by us. Surpasses anything in apricots we have ever seen and commands double the price of ordinary varieties on the Wichita markets. The tree is a beautiful upright grower, making it especially suitable for lawn planting. The fruit is bright yellow with a red cheek. It is a perfect freestone. The Edrington is double the size of ordinary varieties and of most delicious flavor. We consider this to be our best apricot. Ripens in July.

SUPERB-One of the best apricots now being offered. It is a nother Kansas product, originating near Lawrence. It is especially adapted to Kansas and adjoining territory. The tree is large and spreading, with broad, glossy leaves. Excellent quality and a beautiful yellow with slight blush. Ripens after Moorpark.

MOORPARK - The fruit is large, orange-yellow with a red cheek. Sweet and rich. A freestone. Ripens in early July.

ROYAL-Medium size, roundish, dull-yellow, sweet and highly flavored; freestone. Last of June. 


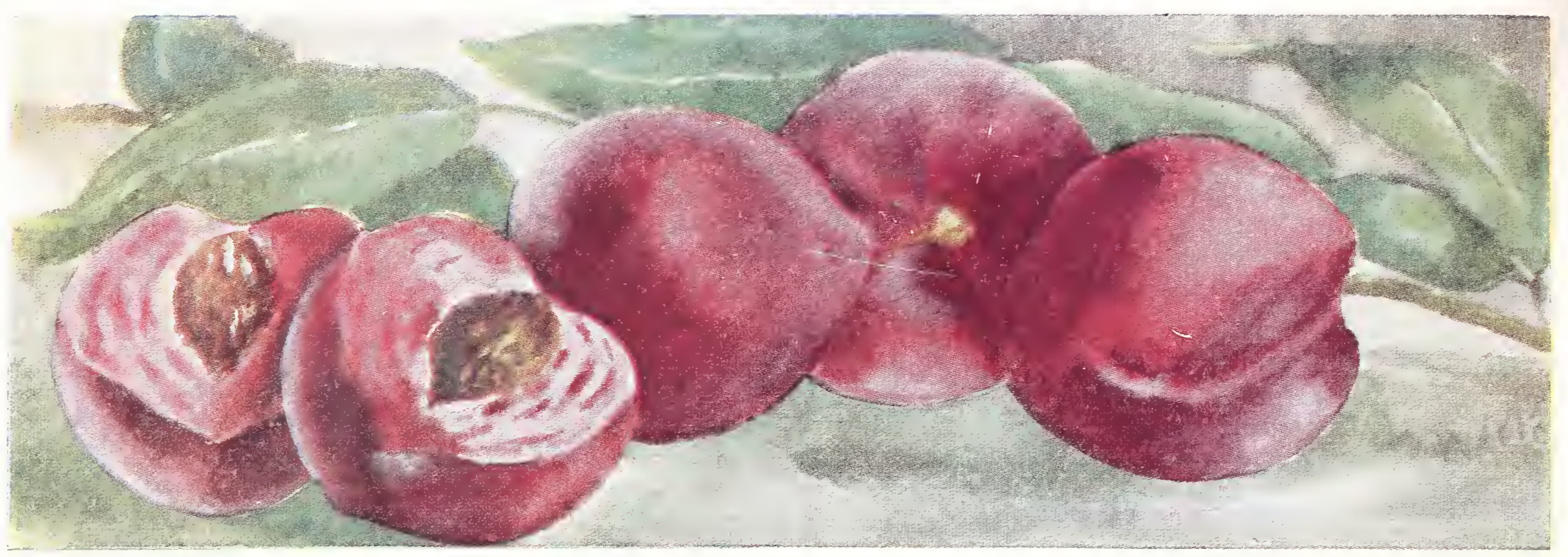

Japan Blood Dwarf Peaches

\section{Peaches}

The most excellent of all fruits and if given the proper care and attention it is one of the most profitable. No fruit commands better prices in its season. A commercial peach orchard is an investment which will yield almost unbelieving returns at an early age. In the home orchard the peach is indispensable. You, who have depended on the market for your peaches, know that the supply will never equal the demand. And, of how much better flavor is the fresh fruit picked off your own trees than that which has been picked green and shipped a long distance. You will never know the real flavor of the peach until you have the opportunity of picking your own fruit.

Tre use the same care and diligence in selecting our budwood for our peach trees as in apple trees. We are fortunate in that our nurseries are located in the heart of the commercial orchards in the rich fertile Arkansas River Valley. The know varieties, seeing them fruiting year after year. We are only listing such varieties which we know to be the best. Discarding old and obscure varieties, we are listing in their place the newer and better improvements. All of the varieties we list are freestones, unless otherwise noted.

A sandy loam or gravelly soil is best, but the peach will adapt itself to any soil not wet. A northern slope is preferable to southern, as it retards early blooming. Perhaps the best cultivation is frequently shallow, stirring of the soil until July or August followed by a green cover crop turned over in the spring. The trees should be set 16 to 18 feet a part, requiring 134 to 170 trees per acre. Cut back to 20 to 26 inches if a low-headed tree is desired. After growth is started, remove all but three or four branches, distributed as equally as possible to secure a well balanced tree.

EARLY ELBERTA-A sure money-maker for the commercial orchard. Size and color as the late Elberta, but ripens eight to ten days earlier. Slightly better keeper.

MAYFLOWER - Very early, ripening about June 10th. Large, very attractive, as it is bright red. Flesh yellow. Semi-cling. Good size and quality for such an early variety. Very highly recommended for early market or home use. Featured by many at an extra price, though furnished by us at our regular prices. The tree is a vigorous, upright grower, spreading, and bears very young.

JAPAN BLOOD DWARF - This peach cannot be recommended tco highly. It is of Japanese origin; the tree does not grow large but it is an exceedingly heavy bearer and it is necessary to thin the fruit at least half. The fruit is dark red and the flesh red, with occasional light streaks clear to the pit. Juice is blood-red. Freestone. Exceedingly small pit. Flavor unsurpassed; rich, juicy, firm, and in fact the one good early peach in preference to anything we have ever seen. It is splendid for table use, canning and market. Brings double the price of the ordinary early peach. Its fine flavor, firm flesh and beautiful color make it a favorite wherever known. Tree bears very early; frequently a few peaches the first year; good crop the second year. Fruit ripens the last of June or first of July. It is a money-maker unexcelled for any kind of use; very hardy, heavy bearer, and in fact the very best early peach we ever saw. No orchard complete without a few Japan Blood Dwarf, and though they cost a little more, they are well worth it. Plant it without fail.

TRIUMPH - A large semi-cling peach; yellow with bright red cheek. Ripens the last of June.

CRAWFORD'S LATE - Of good size; golden-yellow with deep red cheek. The flesh is deep yellow, rich and sweet, and of very good quality. Ripens around the first of September.

INDIAN BLOOD CLING - A very large cling peach, one of the best for picliling and preserving. Ripens about the first of September.

CHINESE CLING-A large, globe-shaped, creamy-white peach with red cheek. The flesh is white, red at the stc ne. A cling noted for quality, none being better. Ripens between September 1 st to 10th.

"Rogers Nurseries,

December 3, 1927 .

Winfield, Kansas

Dear Sirs: Please send me your catalogue as I am going to need some things in your line. I have ordered from you before when I lived at Keystone, ()klahoma.

Mrs. Thomas L. Hoon.

"Pleased with goods. Many thanks.

Mrs. G. A. DAILEY. 


\section{Peaches-Continued}

REDBIRD CLING-A creamy-white peach, almost covered with red. Large, hardy, and good. An extra early good cling, ripening about the first of July.

EARLY WHEELER - One of the best of early cling peaches. The tree is hardy, vigorous, and productive. The fruit is of good size and of showy appearance, being creamy-white, splashed with red. The flesh is white, and of good flavor. As a home fruit it is one of the best and is a leading early market peach. The Early ITheeler is an established favorite among our Oklahoma friends.

ROCHESTER - A remarkable new early peach of the best quality and productiveness. While it is a new variety for the middle west, its quality, hardiness, and good bearing qualities have made it a general favorite in $N$ ew York and other eastern states the past few years. It is being recognized as one of the best early varieties. Coming into the market during the early season it commands not only the highest price, but a ready sale. It is an early leearer, often producing fruit the year after planting. It is not only an ideal home orchard variety, but an excellent commercial peach as well. The trees are hardy, vigorous and productive. The fruit is large, yellow mottled with red in color, with thick, firm, juicy flesh, rich and sweet in flavor. Include Rochester in your order.

WONDERFUL - Large yellow freestone; fruit red at the stone. Very desirable for late season. Septemler $10 t h$ to 20 th.

HEATH CLING - Said to be the oldest named peach in cultivation. Few varieties, if any, are healthier, hardier and more vigorous than Heath Cling. It is the best peach for preserves or pickles. Flesh white, skin well colored, Ripens in late September.

FITZGERALD - A large handsome yellow peach. The tree is hardy and moderately productive. The fruit is of excellent quality, firm, tender and sweet. A fine variety for the home orchard, ripening during the latter part of August.

HENRIETTA CLING-Yellow with a crimson blush. A large, firm, juicy peach of most pleasing flavor. Alout September 20th.

KRUMMEL-Golden-yellow, bhushed red and carmine. I-arge, round, melting, sub-acid, good. Another new peach that is fast gaining in popularity. Ripens in the latter part of September.

CHAMPION-A white-flesh peach of superb quality and fine appearance. The tree is the strongest grower on our list, exceedingly productive and more hardy than the average peach tree. Our Champion should be included in your order. It represents the standard of quality among white peaches. Ripens during the middle of August.

BELLE OF GEORGIA - A creamy-white peach with a beaultul crimson cheek, grown largely as a commercial peach, but should be in every home orchard. The trees are hardy, vigorous and very productive. Of excellent quality but in many of our customers'opinion it is not quite the equal of our Champion., Ripens a few days hefore Champion.

CARMAN-We belive this variety is able to adapt itself to more types of soil and weather conditions than any other sort and is a favorite with every commercial grower, as it ripens ahead of any other white peach, commanding a good price on the market. The color is a brilliant red splashed with darker red on a creamy-white background. The Carman is very good in quality. You will like it.

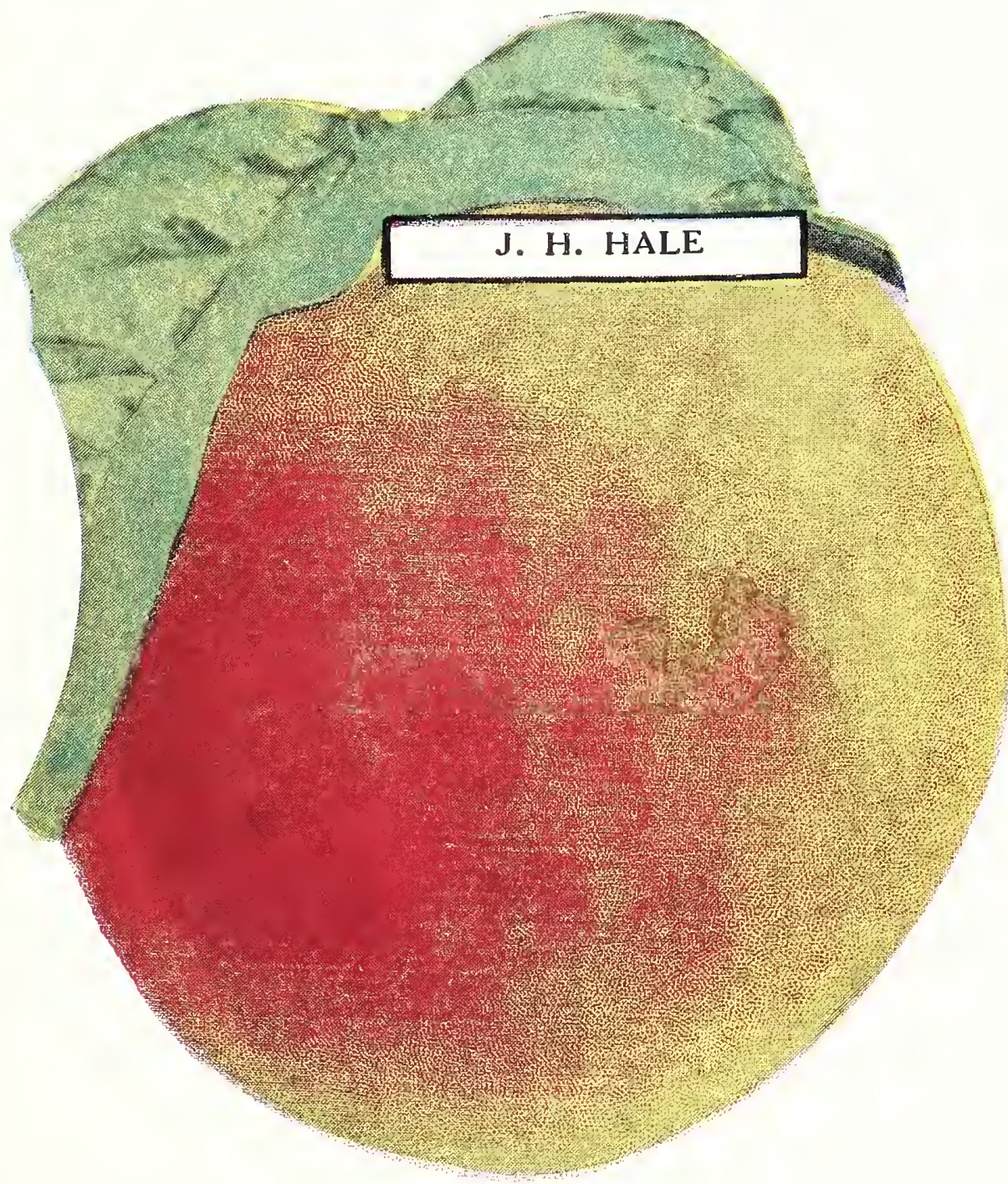

MAMIE ROSS - This is a white cling peach, having a red cheek. The fruit is large, round, sweet and rich. The tree is very prolific and never fails to produce annual crops. It ripens the last of July.

ELBERTA - Beautiful yellow, large and shaded with red. Elberta has been the peach for years and is just as good today. The fact that more than 80 per cent of commercial plantings are of this variety speaks well enough for it. We never knew a planter to be disappointed in Elberta. You will prize it highly because of its regular heavy and abundant crops. It is the queen of peaches in the Southwest. August 15 th to September 1 st.

J. H. HALE-When the J. H. Hale was first discovered it was thought to be identical with Elberta. It is a yellow freestone and of the same type of a commercial peach as Elberta. but considered by many to be better. We believe J. H. Hale to be as productive as Elberta and the record of this peach up to date warrants the planting of it over a wide area. It ripens a few days earlier than Elherta. It is of a deep golden-yellow color overlaid with bright carmine and of the best quality. Whether you are ordering for a home orchard or a commercial planting, we want you to plant J. H. Hale. 
Compass Cherry-Plum trees bear extremely early, always, if the season is at a 11 favorable, the year after planting. Compass $\mathrm{Cher}$ r Plum is an annual bearer and very hardy.

It is indeed an extraordinary Cherry-Plum of which too much praise cannot be given.

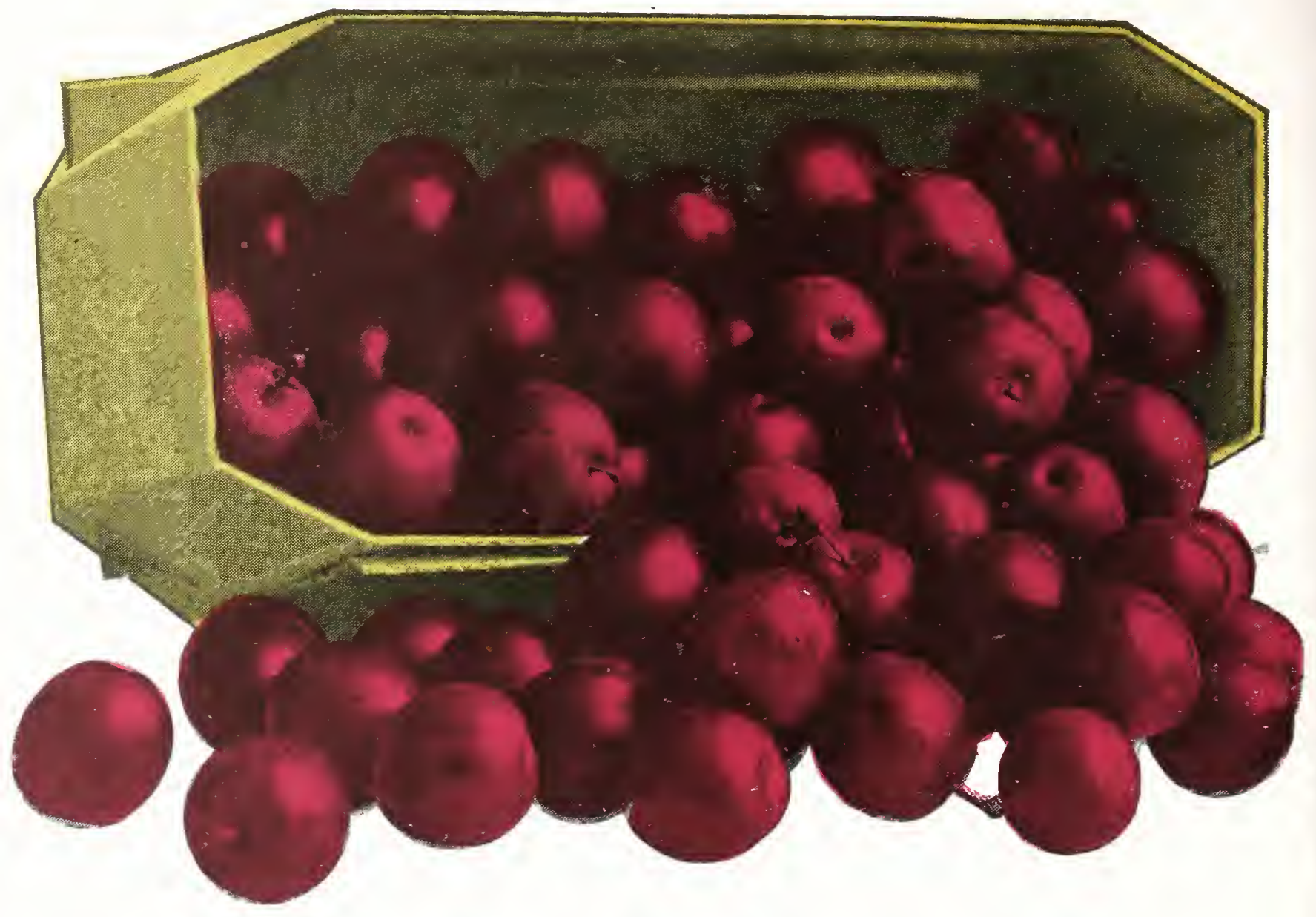

\section{Plums}

Compass Cherry Plums

\section{Compass Cherry Plum}

It is absolutely hardy everywhere. Originated at Springfield, Minnesota. It is a cross between the Sand Cherry and the Miner Plum. The fruit is nearly an inch in diameter; bright red, sweet and juicy, and of very fine flavor. When young and green the fruits have the appearance of plums, but as they mature become round like a cherry. The pit is somewhat elongated. For canning and table use the fruit is unsurpassed. The tree bears young, regularly and abundantly. Should produce some fruit the next year after setting out. Does well from Texas to North Dakota and is especially valuable for all parts of Kansas, Oklahoma, Missouri, Nebraska and Colorado.

Plums are especially good for eating fresh, for jellies and preserves, and are unexcelled for canning. Some varieties will thrive wherever apples or peaches can be grown. Most of them, especialiy the northern Hansen types, bear the third or fourth year. One of the best fruit trees for the home garden and very profitable in the commercial orchard.

ABUNDANCE - The tree is small, but hangs loaded down with fruit. The fruit should be thinned to allow room for development. It is one of the hardiest and best of the Japanese varieties. The fruit is large, oval and in color amber, changing to cherry. The quality is very good. About July 5th.

BURBANK - The Burbank is a later and somewhat more vigorous variety than the Abundance. It is a dark red, roundish Japanese plum and of good quality. The flesh is a deep yellow, firm, very juicy and sweet. It is considered to be the hardiest and most prolific of the Japanese varieties.

JAPAN GOLD - A decidedly valuable variety. Golden-yellow in color, slightly overspread with beautiful blush, Delicious flavor and well liked. This variety has been tried in many different localities and never fails to make good. Does well on thin, dry soil. The tree is rather dwarfish, with slender limbs.

RED JUNE - The Red June is a very handsome plum, about a week earlier than Abundance. The fruit is medium to large size and deep vermilion-red. The flesh is yellow, sweet and rich and is very solid for early fruit, ripening about June 25 th. The tree is vigorous and very prolific.

SHIRO - Large, round, golden-yellow plum of excellent appearance and fine quality, ripening in early July. It seems to be very popular with many of our customers.

SATSUMA-Large and flesh blood-red. Bears young and is very prolific in Oklahoma, Colorado and New Mexico. One of the Japan family.

GERMAN PRUNE - We have some calls for the German Prune, so we are growing a few trees. Where prunes are a success the German Prune is a valuable plum of fair quality for dessert, but most esteemed for drying and preserving. The fruit is large, purple, with a thick blue bloom. The flesh is firm, sweet and pleasant, separating from the stone. September.

OPATA-One-year-old trees set fruit buds freely. Our largest size trees will bear the year following transplanting. This variety is a cross between the Sand Cherry and the Gold Plum, a very large plum, for which $\$ 3,000$ was paid when first introduced. The tree resembles the plum in its habit of growth. The fruit is one inch or more in diameter; small pit. It is a dark purplish-red, with
blue bloom.

WANETA-A northern variety. The fruit is bright red, measuring almost two inches in diameter. Recommended for dry climate and where the frost is a habitual visitor. Very hardy and an exceedingly heavy bearer, as it never misses.

HANSKA-Similar to Opata and Naneta. The fruit is of good size and bright red. Flesh is reddish, of delicious flavor and quality. The tree is a strong, upright and vigorous grower.

SAPA-Dark purplish-red in color and of excellent flavor. Bears early and heavily. The tree is spreading and bushy. 


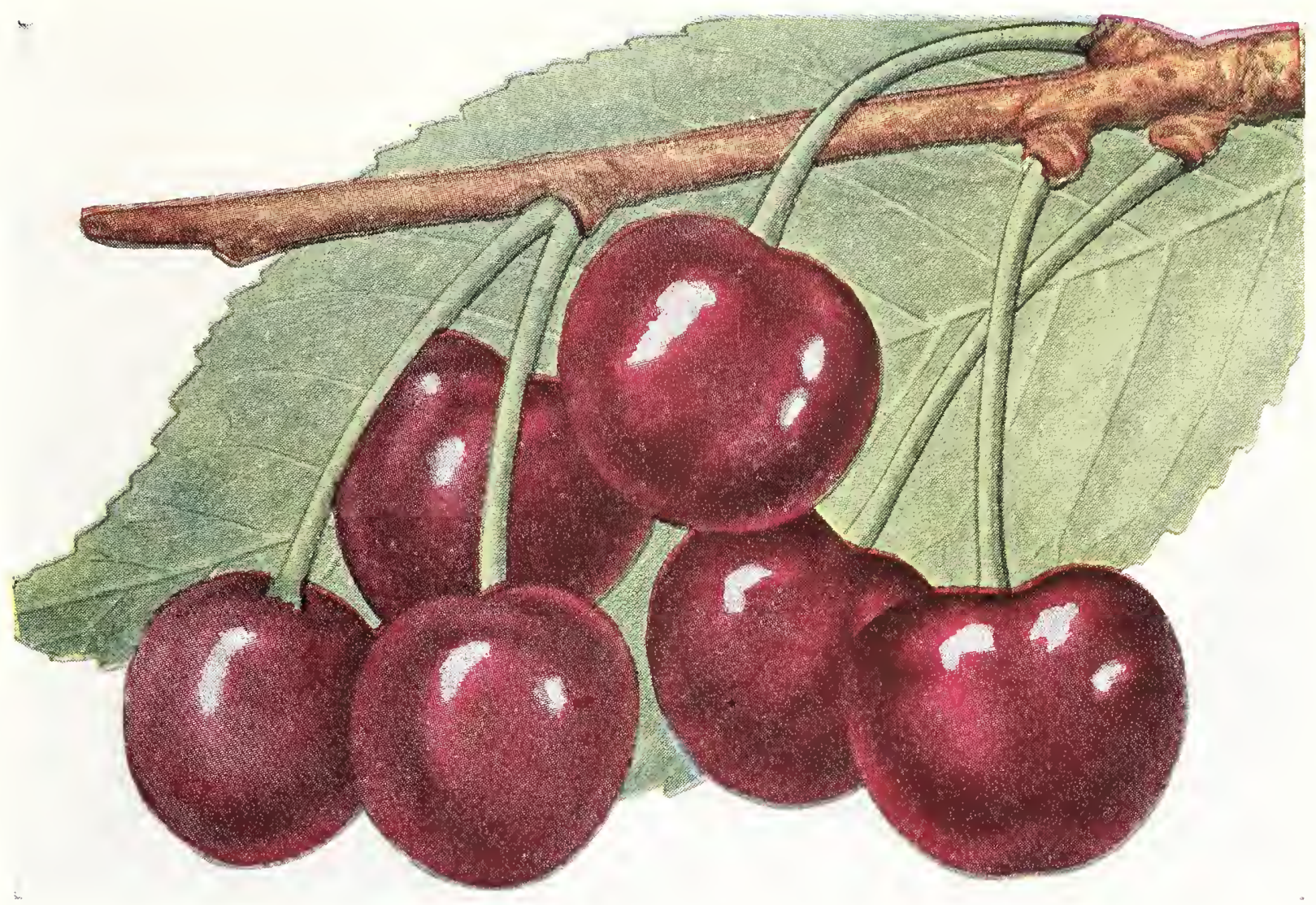

You remember, of course, the big, rich, juicy Cherries for which you climbed the tree when a boy. Why deprive yourself and your children of the same pleasure today? You can have all the rich, juicy Cherries you wish if you will plant some of our justly famous Kansas Duke Cherry trees.

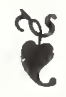

Remember, too, the Cherry made the pie famous, and who doesn't like Cherry pie?

Kansas Duke Cherries

\section{Cherries}

Cherries are one of the most popular fruits. Its hardiness, and the fact that it bears annually are strong recommendations. The cherry can be grown on any kind of soil, but prefers a moderately heavy loam. The soil must be well drained. Cherry trees will do better under neglect than any other fruit tree. They need very little attention after transplanting; no pruning and very little spraying. Being interested in cherry trees for a commercial orchard, you are on the right road to prosperity. Cherries pay big dividends within a few short years. They come into bearing the third or fourth year after planting. There is a heavy demand for cherries. A small eight-acre cherry orchard adjoins o ur nursery fields. The owner cleared over $\$ 1,500.00$ from this small tract last spring. A few days before his cherries were ripe he placed a few advertising notices in the local paper and on the date he announced his orchard to be open to the pickers, our neighbor orchardist advises that people, who had driven considerable distance were actually in his orchard at four o'clock in the morning. By five o'clock that evening not a single cherry remained on his trees. The people gladly picked the fruit and paid five cents a pound for Early Richmond and Montmorency. This same orchardist had a few trees of our Kansas Duke in bearing for which he charged twelve cents a pound. He is very enthusiastic about our Kansas Dukes and intends to set several hundred more of this variety. You may not have eight acres or even one acre to use for cherries, but you have room, even though you live in town, for a few trees. If you ever tasted any fresh and ripe cherries from the tree, you will surely want a few trees of your own. If you only have room for one tree and neglect to plant a cherry, you don't deserve to eat a cherry pie or any of the delicious fresh fruit.

KANSAS DUKE - Our Kansas Duke is a large semi-sweet cherry of deep red color, juicy and rich. The flesh is reddish. It is the only sweet cherry which has met with any success in. Kansas and Oliahoma. The fruit is of the best delicious flavor and is very excellent for eating fresh. We have one Kansas Duke in our backyard and when the fruit is ripening our folks start picking and eating until the tree is bare. Kansas Dukes sold for 12c per pound on the tree in the Albright Orchards while Early Richmond and Montmorency were commanding a price of 5c per pound. Plant a Kansas Duke cherry if you have room for only one tree. The tree is especially attractive as it is an upright, compact grower, which, together with the heavy dark green foliage, makes it a beautiful tree for lawn planting. The Kansas Duke is a prolific bearer and the abundant crops make it especially desirable for commercial use. It is the nearest sweet cherry that is a success in this climate. Ripens about a week before Montmorency.

DYEHOUSE - One week earlier than Early Richmond, which the fruit resembles, except that it is a little darker. Of good quality.

EARLY RICHMOND - Sometimes called the Early May Cherry. It is the favorite early cherry and next to Montmorency, the most popular of all the sour cherries. The fruit is of medium size, roundish shape, flattened at the end; flesh light color tender and sprightly. A good canner. The tree is medium size, vigorous, upright, spreading, productive and long-lived. Ripens about a week earlier than Montmorency. We suggest that you set one-half of your sour cherries to this variety and the other one-half to Montmorency.

MONTMORENCY - With Early Richmond, it is the most widely and numerously planted cherry and the most productive and regular bearer. Colors early before ripe. The fruit is roundish, plump flattened at the end, and a beautiful glowing end . It hangs in clusters. The flesh is rich and pleasant; of reddish color, tender and firm. A good shipper and canner. The tree is a vigorous, upright grower, but will not quite equal Early Richmond in production qualities. Ripens about the second week in June.

WRAGG-Large, roundish, and heart-shaped. Dark crimson and when fully ripe is nearly black. The flesh and juice light crimson, firm and good; very productive. In some localities the Wragg is one of the hardiest and is usually a sure-cropper, but for southern Kansas and northern Oklahoma, it cannot compare to Montmorency or Early Richmond.

BING -Very dark red, almost black; large sweet cherry of good quality. Fine for Colorado but will not bear here.

LAMBERT - Of the same type as Bing. Another sweet cherry for Colorado and other localities where this type will bear successfully. 


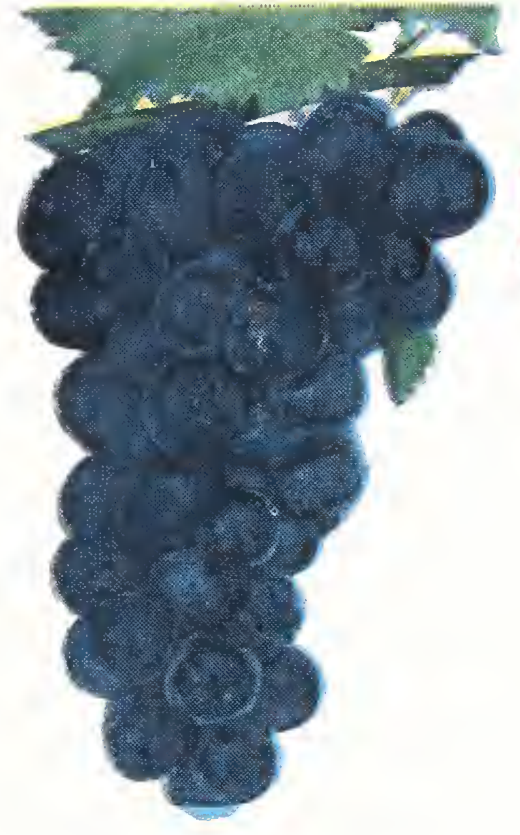

Moore's Early

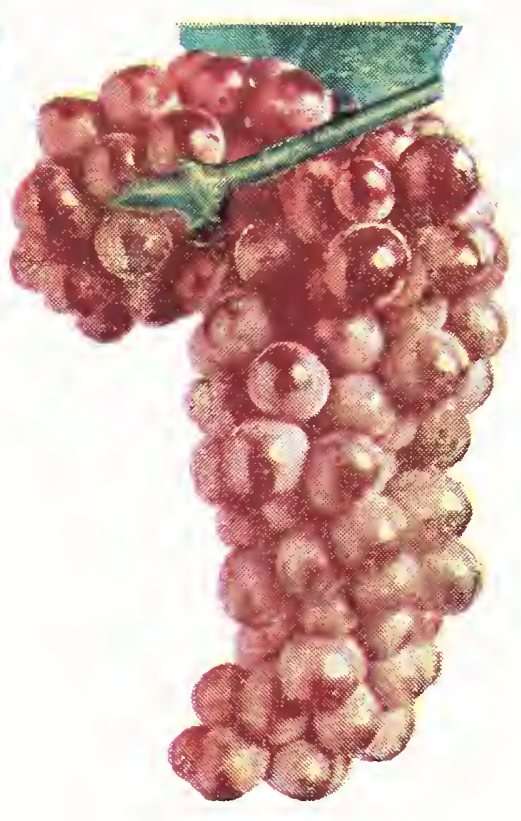

Agawam

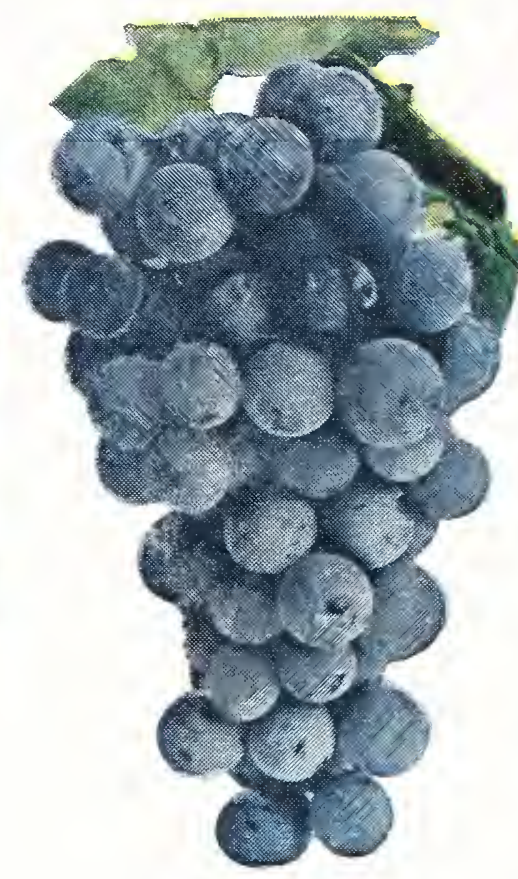

Campbell's Early

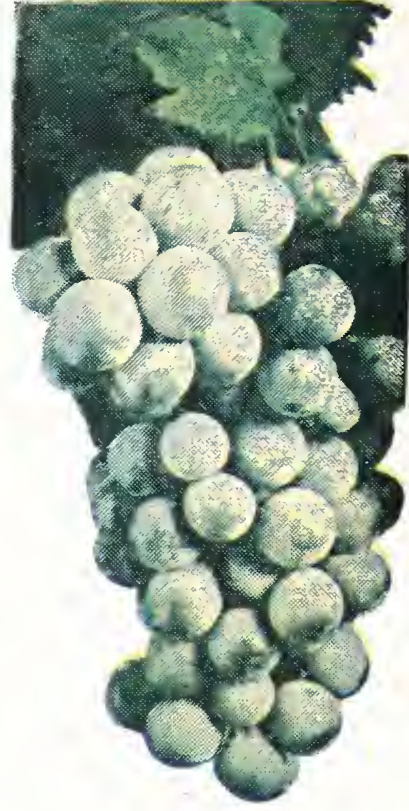

Moore's Diamond

\section{Grapes}

The grape is one of the most dependable of fruits. They are hardy, vigorous, and very productive-has never been a failure of the grape crop here-and they begin to bear heavy and abundant crops at an early age, usually the second or third year. I don't know of a nything which will bring surer and larger returns on the investment than a grape vineyard of a few acres. Every garden should have a few grapevines. You ahways have room some place for a half dozen or more. They take up little room, are quite ornamental on arbors or trellises, and produce good abundant crops even though neglected. Like anything else, grapevines respond quickly to care and attention and will handsomely repay you for the extra efforts you put forth. The earliest varieties of grape start ripening about the last of July in the South and the first of September in the North. The season extends over a period of four weeks in the South and about six weeks in the North.

Fortunate in having extra rich fertile soil in our nursery fields, we can grow a grapevine in one year which will equal the average two-year vine grown in the east and south. We don't wish to pat ourselves on the back as being such extraordinary good growers, but we have the right kind of soil and a long growing season which does the work for us. All that we ask is that you give us at least a part of your order so that you can compare our grapes with stock offered you by other nurseries. Our grapevines are extra heavy, well-rooted plants, very thrifty and full of vitality. If our stock does not prove satisfactory to you and back up our word, return it at our expense. Your money will be returned.

CAMPBELL'S EARLY-Bunch and berry better than the average black; of fine quality, and keeps long after ripening. Ripens with Moore's Early, and we believe it to be a better grape.

MOORE'S EARLY - Bunch of medium size and compact. The berry is very large, black and of gcod quality. Bears regularly, but not as heavy as Worden. It is a good market grape on account of its earliness, ripening the last of July.

WORDEN - The best black grape we have found. The bunch is large, compact, and ripens evenly. The berry is large, thin skin, and very fine flavor, rich and very sweet. The vine is perfectly hardy, bears heary and is very prolific. The fruit readily sells at double the Concord price.

CONCORD - The old, well known black grape, being of good flavor and fair quality. The vine is hardy and bears heary crops with regularity, ripening about the third week in August.

NIAGARA - We believe this to be the best white grape grown. The bunches are large and long. The quality is of the best. Very hardy, bears regular and abundant crops and proves profitable as a commercial variety here. Comes in just after Concord.

AGAWAM (Rogers' No. 15) - The most widely grown of the Rogers' Hybrids. The bunches are large. The berry is large, rich and sweet. The vine is vigorous. The Agawam ripens after Concord and can be kept much longer and improves in flavor. Seems to prefer clay soil. Of the red grapes, it is the easiest grown and one of the most dependable. For home and market use.

SALEM - A rich, clark red, early grape of excellent flavor, as a re all Rogers' Hybrids, ripening slightly before Concord. An excellent garden variety.

CACO-A vigorous, prolific grower. The Caco is a hybrid produced by hand pollenization of the Catawba and Concord. It is a perfectly hardy grape, beautiful, large, wine-red. Extremely rich, sugary flavor. It is making goct in all soils and sections, so that we can recommend it on the basis of performance. Ripens in advance of Concorrl. The vine is a very strong, vigorous grower, healthy and prolific. The fruit sells in the open market at double the price of other varieties.

MOORE'S DIAMOND - White. Vine is vigorous and productive. Bunches large and compact with berries of good color and flavor. Ripens a little before Concord. 


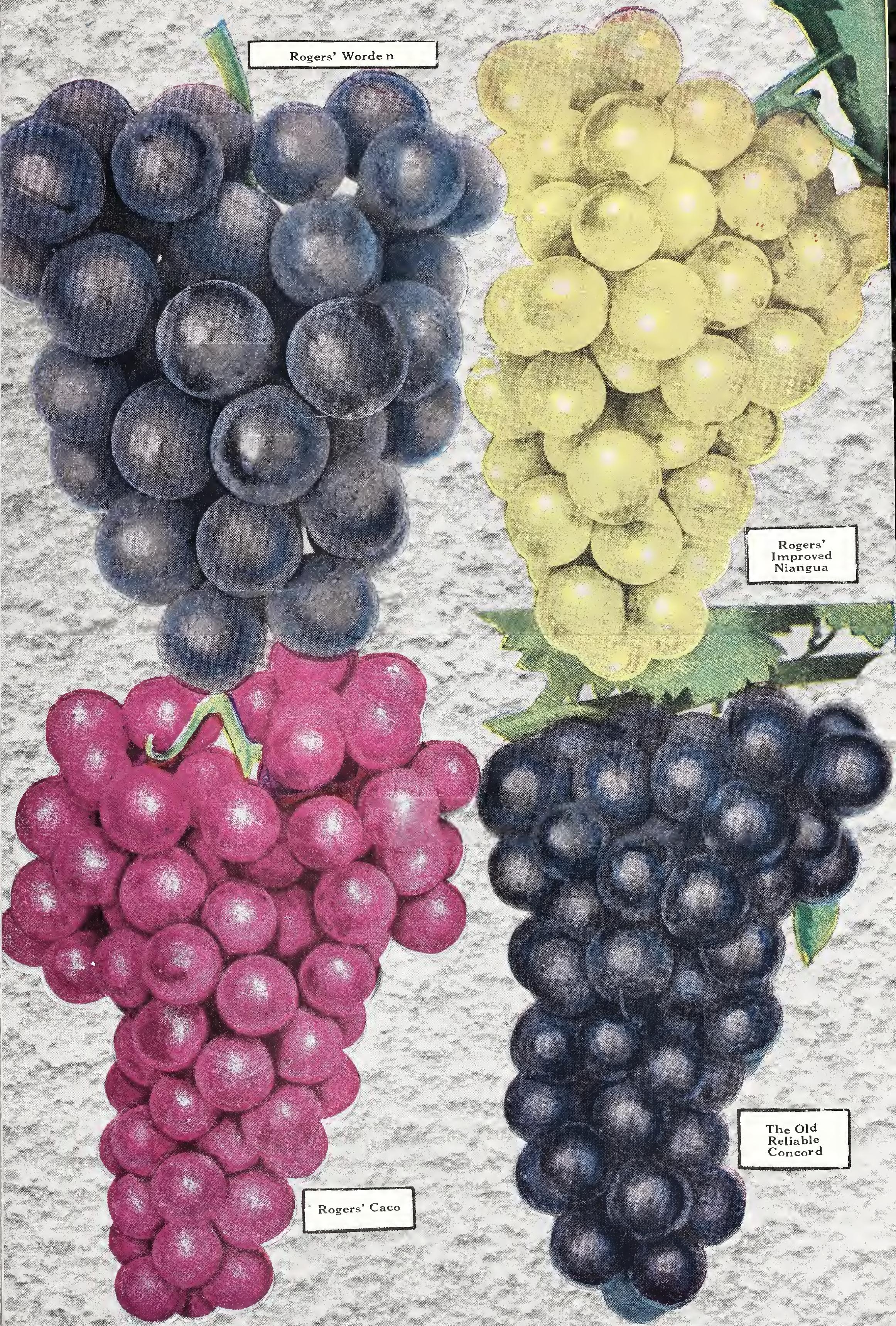




\section{Gooseberries}

An exceedingly profitable fruit when properly handled. The market is never supplied here to any extent. Gooseberries can be gathered and marketed over a long season. Every home garden should have a dozen or so bushes, as you will find gooseberries are very easy to grow. The fruit is extremely desirable for many uses. Gooseberries and currants require very little room and attention. They will prove satisfactory under orchard trees or similar semi-shaded locations. Gooseberries bear most freely on two and three-year wood, so pruning should maintain a continuous supply of vigorous wood.

OREGON CHAMPION - The berries are extra large, round, smooth, greenish-white with thin, transparent skin; very good quality and ripens early. The bush is vigorous and very free from mildew. Last spring we sold Mr. Mr. B. Kraft of Michita, Kansas, 1,000 Oregon Champion for a commercial planting. Mr. Kraft knows Oregon Champion, and realized the profit which can be made in gooseberries. On September 4th he advised us that he had a small loss and then goes on to tell that "the rest of the Champions have grown fine, most of them above knee-high." The have not listed Oregon Champion before this year. On Mr. Kraft's recommendation we are passing it on to our customers.

HOUGHTON-The old standard variety; bush drooping, hardy and prolific.

DOWNING - Larger than the Houghton, roundish; light green, juicy, fine quality; bush more upright than Houghton.

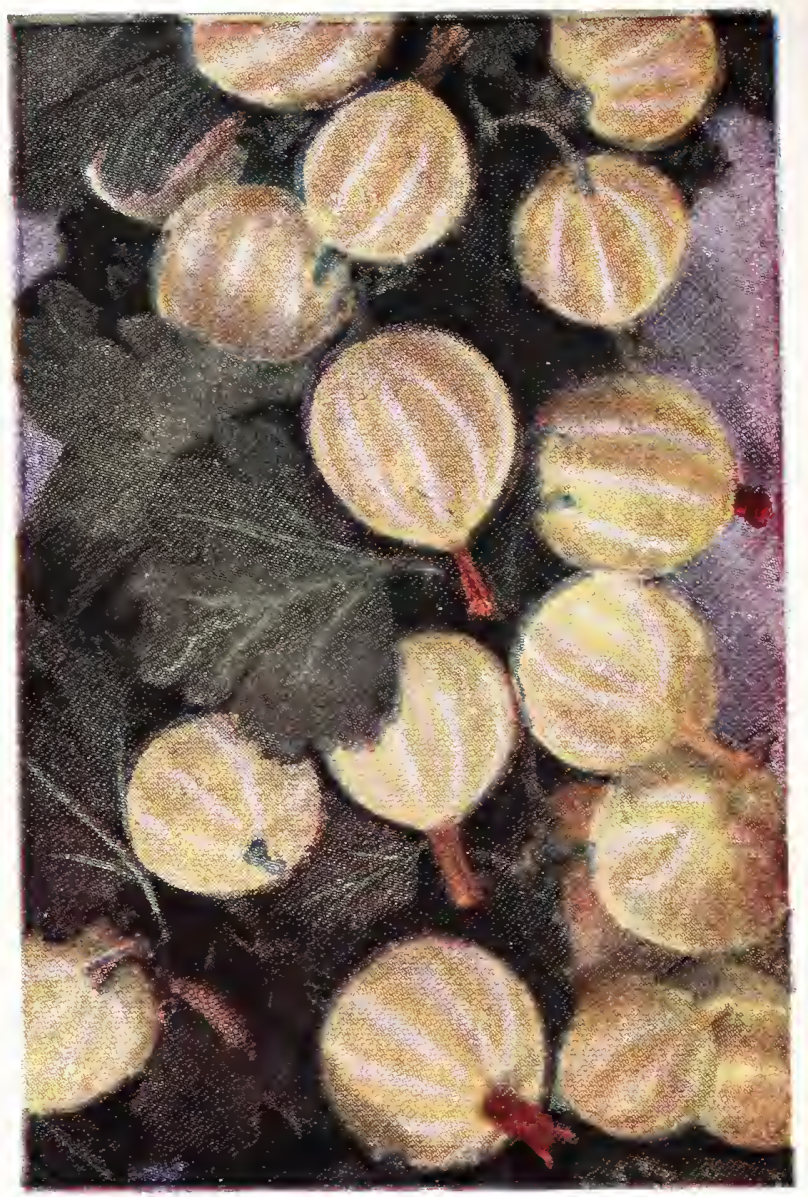

Houghton Gooseberries

CARRIE - This variety originated in Minnesota and has proven hardy and vigorous in nearly all sections. The plant makes an exceptionally strong growth and produces large crops of berries than any other variety we offer. IThen fully ripe the berries are red. Quality good.

PEARL-The finest berry we have tasted; very large, round, juicy, extra quality. Small two-year bushes of this grand new variety tried here were covered with berries which measured one inch in diameter.

\section{Currants}

CRANDALL - Very large Black Currant, originated by A. Crandall of Newton, Kansas: bears young, regularly and very abundantly; needs no protection; fruit sweet, huckleberry flavor, very juicy. Ripens early.

FAY'S PROLIFIC-Large clusters, and one of the finest of Red Currants.

CHERRY - The largest of all red currants; berries sometimes one-half inch in diameter; bunches short. Plant is vigorous and productive when grown on good soil and well cultivated.

- NOTE-Me list currants for our northern trade. Unless planted in the shade the red currants are practically worthless south of Wichita. The black currant is slightly better, but could not be termed a success.

\section{Dewberries}

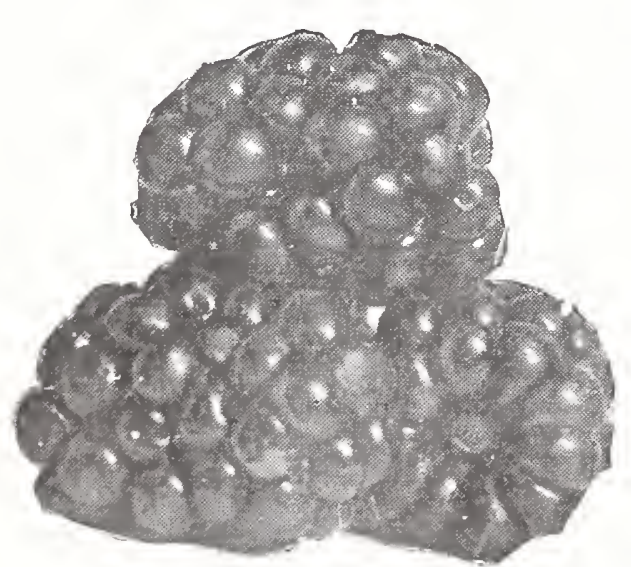

Thornless Dewberries

The Dewberry is a dwarf and trailing form of the Blackberry. The fruit is highly prized as a market fruit owing to its large size and fine quality. Set the plants two feet apartin the row and cover in winter with coarse litter. Should be mulched in the spring to keep the fruit off the ground.

LUCRETIA - The best known and widely planted Dewberry. The fruit is large and of good quality, very sweet and of delicious flavor. The canes are very vigorous and productive. Ripens early.

AUSTIN-Similar to I-ucretia, but not its equal in the north. Recommended for our southern Oklahoma and Texas trarle. It originated in Texas.

THORNLESS - This dewberry is absolutely thornless. The bush is very rardy and makes a vigorous growth. Although being a late introduction the Thornless Dewberry is of proven merits. It is a good bearer. The fruit is very large, jet black, juicy, sweet and of very fine flavor. We have seen this dewberry hearing in the nursery row. Order at least a few of these plants for your garden.

\section{Blackberries are listed on page 17}

Oklahoma, Dec. \&, I927.

Rogers \& Sons.

Find enclosed \$0.7o for tree order, received in good condition. Thanking you for the free Rose and for the Raspberry plants that you made good without any charges and the Peach trees at one-half price. Thanking you again. MRS. PANSY NASH.
Oklahoma, Nov. 26, 1927.

"The last bill of trees you sent me sure looked fine. thank you. I think you will get some orders from my neighborhood in the spring. I am talking for you people. Yours very truly,

J. W. RICHARDSON. 
The market for Strawberries is already created; so why not grow them and supply it?

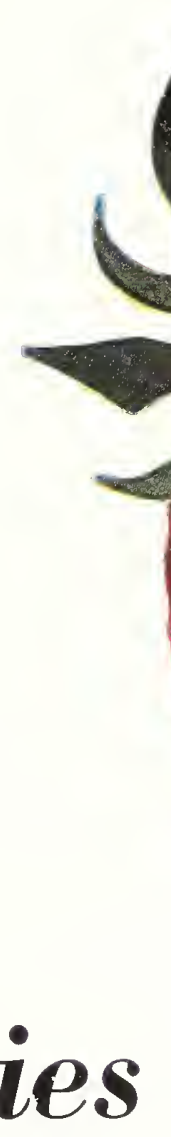

\section{Strawberries}

No other fruit gives such quick returns on the investment as strawberries. Commerciaily, they are one of the most profitable crops. It is just as easy to grow strawberries for home use as your vegetables, and always have the supply ripe and perfectly fresh. Whoever heard of anyone having all the fresh strawberries they could eat? How many dishes of fresh strawberries and cream can you eat, with the price of strawberries ranging around $\$ 4.50$ per crate? But if you set one, two, or three hundred plants in your garden we assure you that you will have all of the fresh

strawberries you want and still have several crates to sell to your neighbors. We know of several Winfield people who sold forty or fifty dollars' worth of strawberries, after eating and canning all that they cared for, from a small garden plot last spring. There is no secret about growing strawberries. Give them the same care and attention that you give the rest of your garden. If you want your son to do a little work for his spending money, give him the use of your vacant lots. Buy him a thousand or so of our well-rooted strawberry plants. Should he make a total failure the cost to you will be but little. But we will venture to say that in addition to the experience and fun, he will have quite a tidy sum of money to show for his efforts. We are only growing and listing the varieties which a re best adanted to this locality. On our testing grounds we have given them a thorough test; and none are better for Kansas and Oklahoma than the varieties listed below. Our plants are dug fresh the day your order is shipped and we pack the plants carefully so that they will reach you in good condition. Set the plants just deep enough so that no parts of the roots are exposed, yet not deep enough to cover the crown, seeing that the earth is well firmed about the roots.

\section{Mastodon Everbearing Strawberry}

Without a doubt this is the everbearing Strawberry. In the spring crop the berries are large, sweet, well flavored and will equal Senator Dunlap for bearing qualities. It bears excellently during the summer months and also does extra well during the fall bearing season. This variety is good and we heartily recommend that each of our customers buy a hundred or two hundred plants for their garden.

CHAMPION (Everbearing)--The berries are larger than Progressive, quality as good or better, and a rich red color. For a family of two or three 100 to 200 plants will amply supply your table.

PROGRESSIVE (Everbearing)_- The fruit and plants are quite similar to the Senator Dunlap, but the bearing season is much longer. If weather conditions are favorable, with plenty of moisture, the Progressive will bear all summer, or by keeping blossoms picked off after spring crop till latter part of August, will being on a gocd fall crop.

SENATOR DUNLAP_-There is no known variety that is so universally popular nor one that is so extensively grown as the grand old Senator Dunlap. The fruit is very large, rich red, and of remarkably fine flavor. In addition to this, it is a heavy producer, a splendid keeper, and cannot be excelled for shipping. The fruit begins to ripen soon after the earliest sorts and continues until near the end of the season. The plant is unusually hardy, stands our summer drouths well, and will respond readily to care.

AROMA-Another fine old variety that has retained its popularity down through the years. The fruit is large bright red and of delicious flavor. A good shipper on account of its firm texture. The period of bearing is long and it is a heavy fruiter, but does not bear as heavy as the Senator Dunlap. The Aroma is the commercial strawberry of the Ozark region, because of its good shipping qualities.

KLONDIKE - The leading market variety of the Southern States and a favorite among our Oklahoma friends. Does not do so well further north. The berries are of medium size, deep crimson, quality fair to good. The foliage is resistant to disease. The plants make runners freely. The berries ripen evenly and are firm enough to ship long distances. 


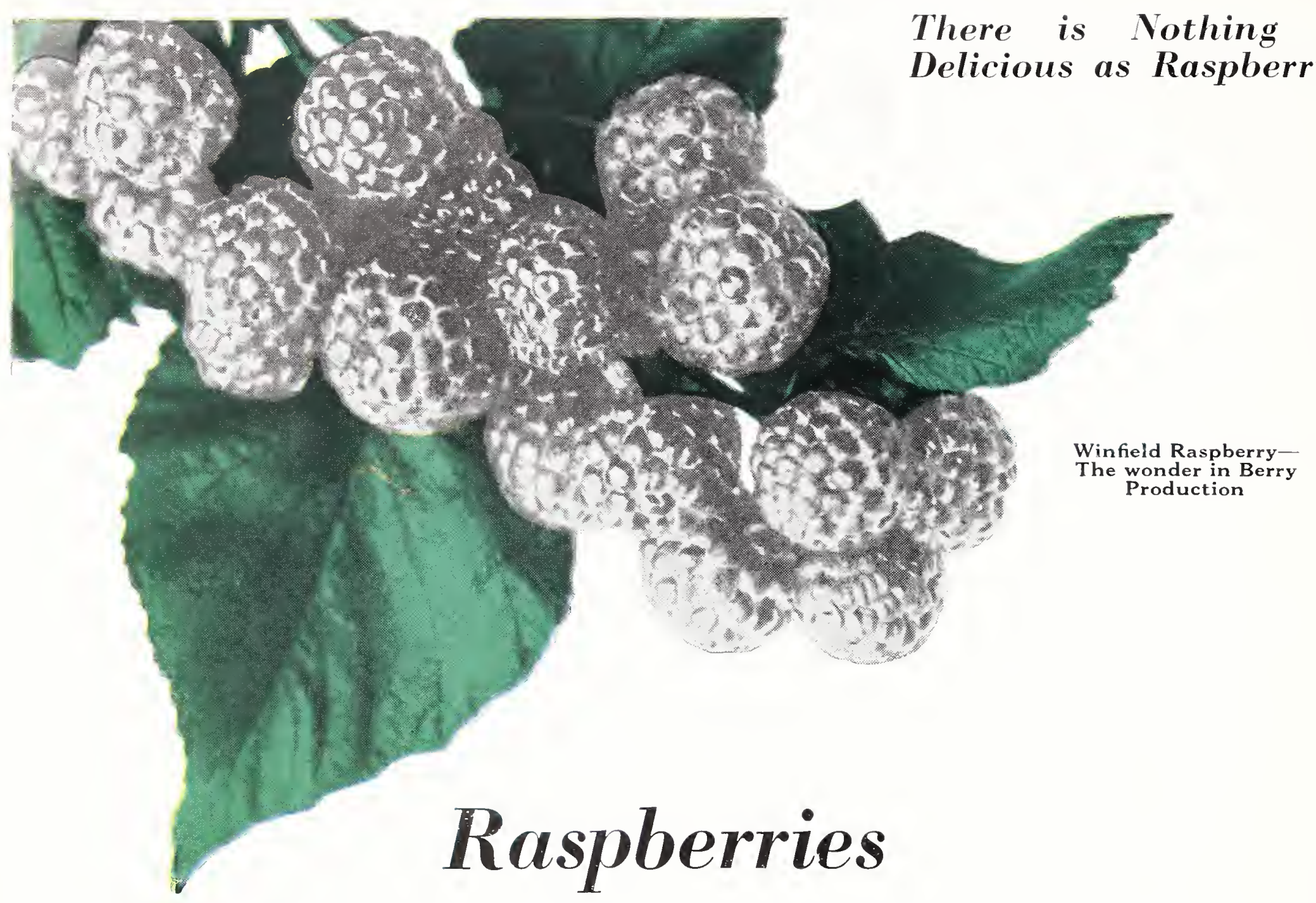

Rich, sweet fruits that everyone knows and likes. We do not believe that there is a fruit crop that will pay better dividends than Raspberries. Very few people have any Raspberries in their gardens and we are unable to understand why it is. They are easily grown, very productive, but unless you have some Raspberry plants of your own you simply do without the fruit as it is to high in price. We don't raise any kind of plants for fruiting, but out of our raspberry propagation block we have a nice little crop of raspberries every season, selling them for $\$ 8.00$ per crate. With good care Raspberries will produce good crops every year, and the demand always far exceeds the supply. You will find a small Raspberry patch a mighty profitable investment, besides supplying you with all the fresh Raspberries, jam and canned fruit that you want.

The Raspberries we offer you are two-year, heavy. well-rooted transplants. These plants are well developed and will prove satisfactory. We can sell you the one-year tip plants at the same price as that asked by other nurseries. You will lose a large per cent of the tip plants in transplanting. Often we have a 50 per cent loss in our field planting, so add a little more money and be sure to get good heary transplants.

Plant 3 to 4 feet apart in rows 6 feet a part, requiring 2,420 or 1,815 plants per acre, respectively. Deep soil that will retain moisture in a dry season is preferable, the lighter loam for the red varieties, the heavier for the black. Allow 4 to 6 canes to grow from each plant for fruiting; pinch off the canes when 2 to 3 feet high. Cut out all old canes when bearing season is over, as a cane bears but once. A mulch should be applied the first fall.

WINFIELD - The very best Blackcap we know of. Originated here in Winfield and for the past ten years thoroughly tried out. The plants are especially strong growers and the berries are very large with small seeds. The flavor is excellent and it is a good berry for all purposes. Ripens about a week or ten days before the Kansas. Stands drouth well and often produces a full crop when other varieties fail entirely. Bears abundant crops. On account of its high quality, we have known this variety to bring a dollar per crate more than other varieties. Can not be recommended too highly.

KANSAS - A nice, well flavored little Blackcap which originated some years ago at Lawrence, Kansas. Cannot compare to our Winfie!d nor does it equal Cumberland or Plum Farmer.

CUMBERLAND - The most widely known black raspberry. Planted because of its productiveness and quality. Berries are extra large, fine and sweet. It is usually hardy.

PLUM FARMER - A splendid black rasplerry that has a lready proven itself one of the leading and most profitable varieties. The plants are very vigorous and have a silvery-blush appearance when ripened. The fruit is grayishblack, very firm, a good shipper, attractive and splendid flavor. Fine for evaporating as well as for fresh market or home use.

CARDINAL - The first Red Raspberry we have ever recommended for this locality. Canes hardy, bearing great crops of rich, red berries; a natural VTestern plant; originated at Lawrence, Kansas.

ST. REGIS EVERBEARING-I new red raspberry that is fast gaining faror. Earliest of all red raspherries, beginning to ripen from June 15th to 20th, and bears throughout the summer. Berries are of a bright crimson, large size and fine flavor. Very frequenly bears the first vear, which is unusual in the red varieties. Fruit very firm. making it a good shipper, which, together with its remarkable productive quality, make it a very profitable sort. The canes are stocky, strong and good growers and the foliage is thick and does not sca!d nor sunburn. Standis drouth remarkably wel!. Has made good wherever tried. 


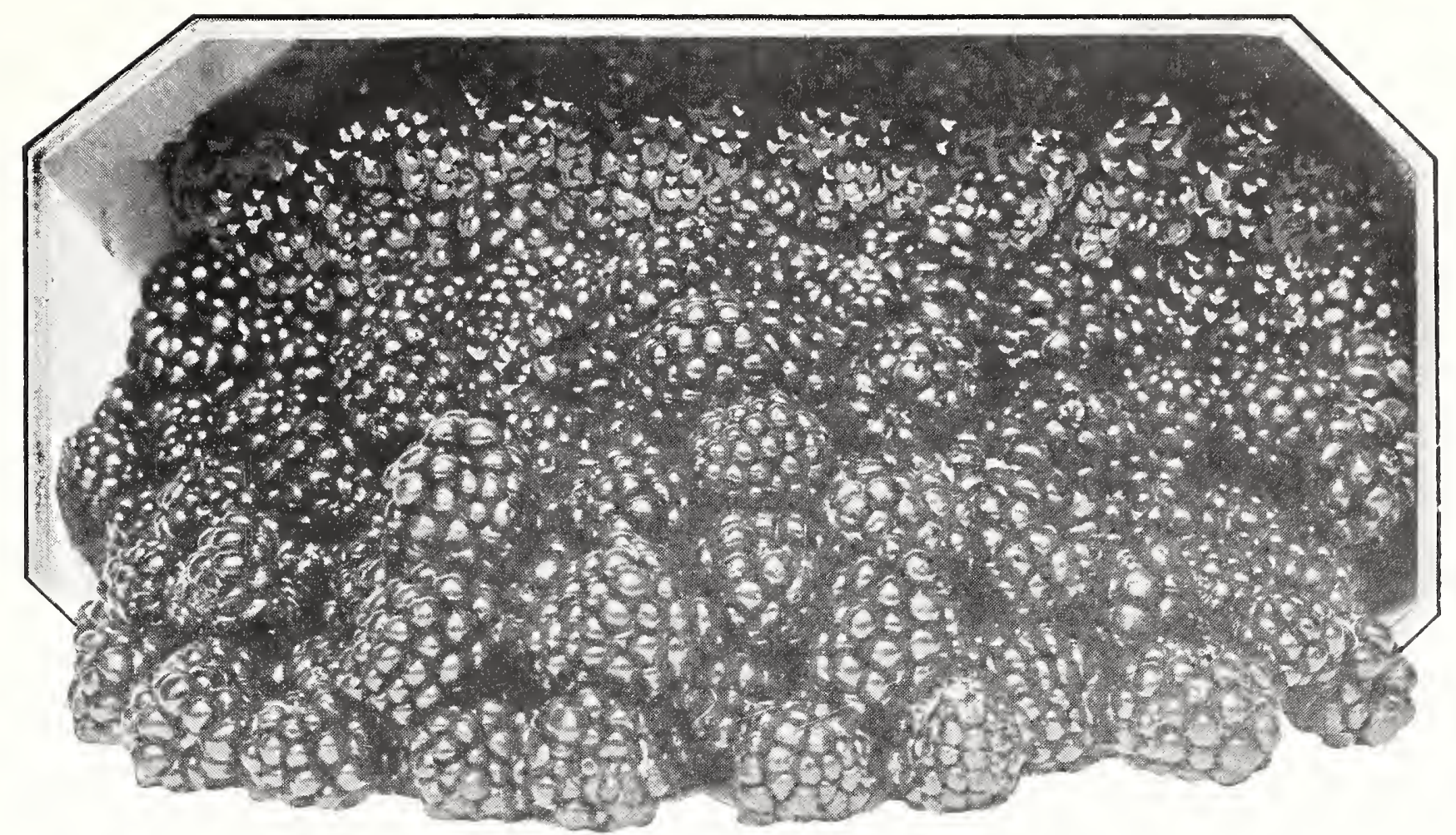

\section{Blackberries}

Mersereau Blackberries

Unless you have a blackberry patch of your own you do not know the delicious flavor of fully ripe blacklberries, since, even for local markets, our commercial gardeners must pick their berries before they are fully ripe. The home cultivated varieties are much jucier and larger and better in quality. They are much appreciated from the home garden for eating, fresh, for canning and preserving. Blackberries are easily grown and bear some fruit the second year. You have room for at least a clozen plants in your garden.

For the commercial gardener there is nothing which will yield better profits and give handsome returns so quickly as will our blackberry plants. Blackberries make one of the best paying crops-five acres in blackberries will earn as much as 160 acres of wheat, with less than one-eighth the upkeep and labor. Try out at least a part of an acre, or better still, an acre or more; plant in rows or "hill fashion." Plant between the tree rows in your orchard; make every foot of your land pay. Blackberries command a good price. Our local blackberry men had extra good crops last season, and yet the demand far exceeded the supply. Our friends, who have blackberry patches, tell us that it is no trouble for them to sell their blackberries, or in fact any of their small garden fruits, and that net profits rarely run under $\$ 200$ per acre.

We offer you extra heavy well-rooted blackberry plants, which have been propagated from root cuttings of selected, healthy, vigorous plants. Our thrifty and vigorous plants will insure you quick growth and a berry crop 20 months after planting. There is a difference between our plants and the ordinary run of piants offered you by many nurserymen. You may pay a few cents more for Rogers' superior strain, but by doing so you get the best and save considerable time-often as much as a season's growth. Oftentimes your neighbors, and some nurserymen, will offer you run-down patch sucker plants for little or nothing. Leave them alone-they are worthless.

Blackberries thrive in almost all soils, but produce best in a strong, deep loam that will retain moisture. Plant 2 to 4 feet apart in rows 8 feet apart. Clip off the points of growing canes at 2 to 3 feet; this will cause the plants to sustain the fruit more readily, increase the yield, and render picking easier.

EARLY HARVEST - This, a long with Mersereau, is our favorite. The bush is perfectly hardy, cane stiff and upright. The fruit is of good size, long, and has very small seeds. The Early Harvest has never failed, despite our occasional dry seasons. In productiveness the Early Harvest is a surprise to everyone, the bushes being weighted to the ground with fruit. If you wish to keep a high standard of berries, don't allow them to waste energy on useless sprouts. Set one-half of your acreage to this early variety.

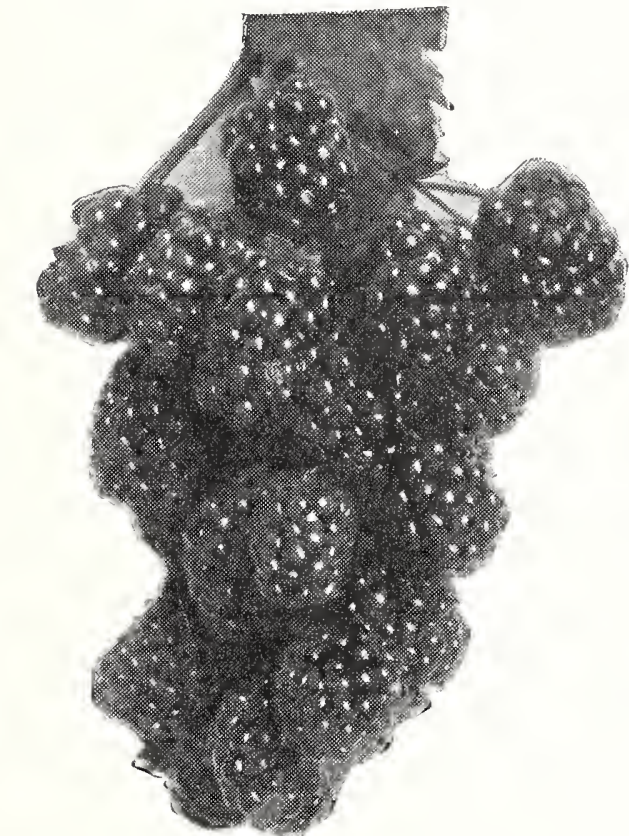

Early Harvest
MERSEREAU - Some nurserymen have a dewberry mixture in the plants which they are offering for Mersereau, which has hurt the reputation of this wonder blackberry. Our Mersereau are of the genuine strain, and we feel that for a late berry no variety is better. Our genuine Mersereau are, without a cloubt, the blackberry of all blackberries. It is very large, jet black, luscious and has all the qualities of an ideal berry. We have never seen any berry that promises so well. We have no hesitancy in recommending this one to all who intend planting blackberries. One week after Early Harvest.

WARD - This is doubtless a seedling of Kittatinny, which it closely resembles. It is vigorous, hardy and free from rust. It was found growing wild in Monmouth County, N. J. Its fine fruit, strong canes, clean, healthy, loaded enormous crops of large berries soon attracted attention. It has now been fruited here for several years, bearing large crops annually of handsome berries. Very highly recommended. One week after Early Harvest.

BLOWER-Comparatively a new variety here. Highly recommended. Large size, good flavor, jet black; good shippers, hardy; prolific bearers. Does not winter-kill, and from all indications is a valuable kind.

EL DORADO - The El Dorado is medium to large in size, jet-black, sweet, and of excellent quality. The bush is hardy, vigorous and productive. The berry ripens in mid-season over an unusually long period and is a n extra good keeper.

\section{Dewberries listed on page 14}




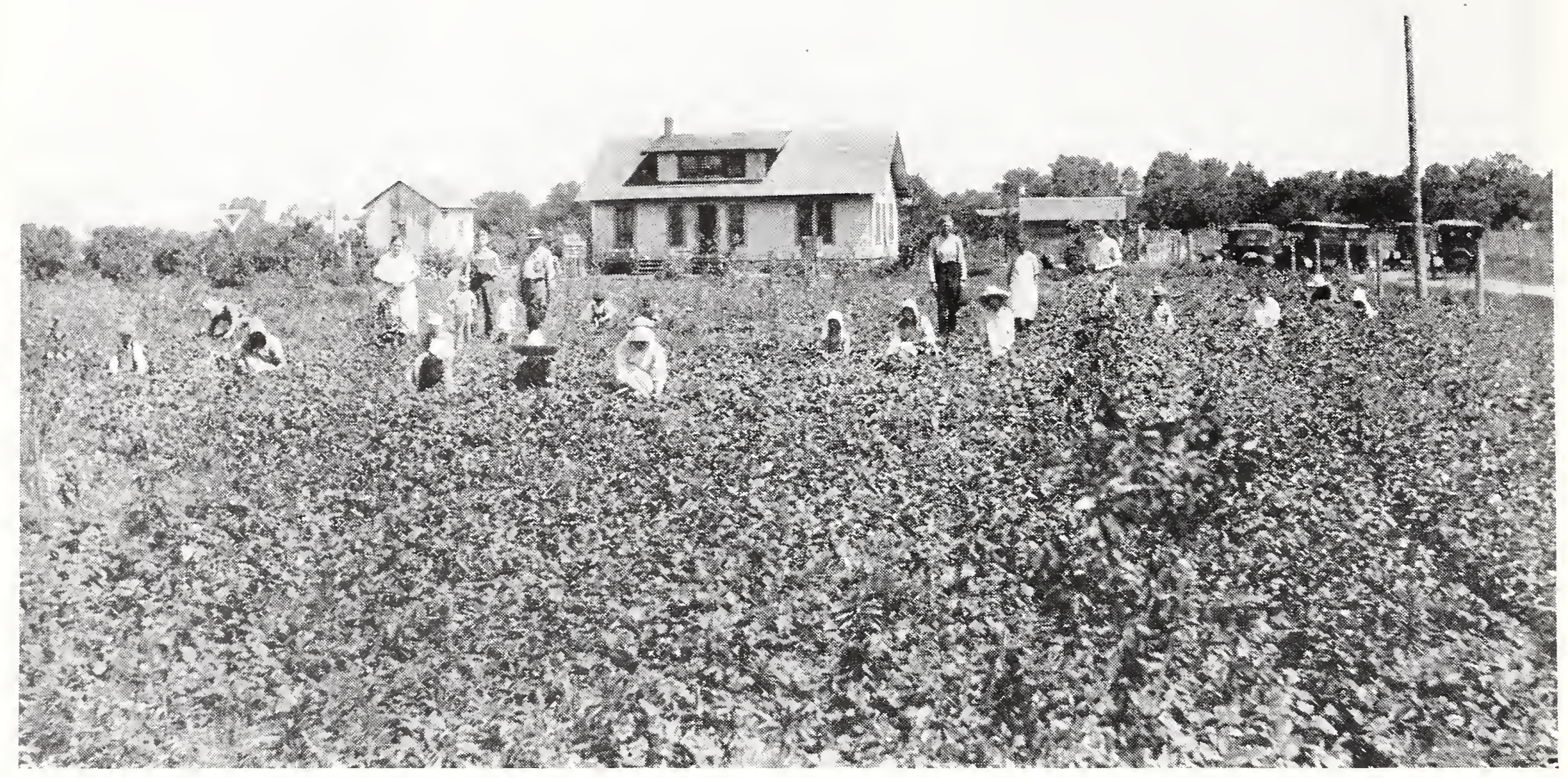

\section{$\left.\begin{array}{c}\text { Mr.J.T. Hamilton's Strawberry Plant in Harper County, Kansas } \\ \text { Marketed over } \$ 7 \text { goo.oo worth of strawberries from this patch of } \\ \text { one and one-fourth acres last spring. }\end{array}\right)$}

Perhaps some of our readers of this catalogue think that naturally we are a little too enthusiastic about our nursery stock. We try only to give the plain facts. Reading letters from our good friends and customers, in which they tell how pleased and delighted they are with the stock purchased of us or how satisfactory the trees have grown, oftentimes we think that we have been too modest in our claims as to what our hardy trees and plants will do.

Believing you to be interested in hearing what some of our customers say, we are presenting some extracts taken from their letters. Postal addresses of any of these customers will be furnished upon request. These letters were taken from our files at random, and are only a small per cent of the number we receive each day. We would like to publish more, especially the photographs we receive, but of course space prohibits.

\section{Adds Beauty to His Home}

Oklahoma, Sept. I2, I927

I ordered about $\$ 18.00$ worth of shrubbery last spring which could not have done better. It is adding so much beauty to our home which causes others to desire similar surroundings. Yourstruly,

$$
\text { ERnest G. SeE. }
$$

\section{Our Trees Superior to Trees \\ Purchased Elsewhere}

Thos. Rogers E Sons

$$
\text { Missouri, Nov. II , I927. }
$$

My Dear Sirs: What would be your price on about 25 Delicious Apple trees, 2-yr.-old-roots; I-year-old-tops?

I need some to finish a row and then I bought a small bill at same time I bought from you last spring and of the other bill, thirteen (13) have died. Your trees are bright and $O . K$. by the side of them

I have had to complain to

about

their trees and do not have their decision yet.

Please let me have your price per tree and I will decide how many I need to complete my orchard. Yours for business,

\section{Jos. V. PitTs.}

B.-My men, as well as myself, all noticed the fine "Root System" your trees have and their superiority over the trees bought from two other nurseries. Ind they appear to be "LIVING"

Margaret Rathburn writes us on November I th: "We received the order you shipped Saturday. Everything was $O . K$

\section{Pleased With Roses Purchased of Us} Kansas, Sept. 26, 1927.

"Mr. Thos. Rogers,

Winfield, Kansas

Dear Sir: I feel it my duty to let you know what luck I had with the nursery stock I bought of you last spring. Everything lived and did fine except the peaches. It was too wet for them. The rose selection is simply fine. They are the wonder of the whole town. I could take orders for 6 selections. I will want about 40 peaches for my own planting and some other kinds of roses not in your selection that you can recommend as perpetual bloomers. I am a rose fiend.

Hoping I can do you some good in the future, I am Yours truly

\section{A SPAFFORD}

Charles Spiva of Oklahoma ordering stock of October Ioth says: "I have got several orders from you and have always been well pleased with them.

After receiving his order, Mr. D. A. Smith lets us know that "I received my bill of goods November and in fine condition and am sending check for same."

\section{From Rogers to Rogers}

Oklahoma, Nov.21, 1927.

'Thomas Rogers $\mathcal{E}$ Sons.

Dear Sirs: The trees I ordered of you came today and have them set out, I am well pleased with them. Yours truly,

C. D. Rogers. 
Oklahoma, Nov. I5, 1927.

'Dear Sirs: I want to tell you about a little order of trees I got from you just about a year ago. I ordered 50 fruit trees and 300 Russian Mulberry. I had fine luck with those trees. 45 of the fruit trees are growing and look fine and practically all of the Mulberry trees are living. They were from 12 to 18 inches high when I planted them. Now, some of these trees are 5 and 6 feet tall. I am well pleased with that order. Am enclosing an order for $\$ 13.65$.

\section{I am, Yours Respt.,"}

\section{Martin Klemme.}

Kansas, Sept. 26, 1927

"Thos. Rogers and Sons.

Gentlemen: I have been waiting for sometime for your agent to call, haven't saw him yet as I wanted some more flowers and fruit. My stuff is all fine excepting one cherry and one apple tree and am sure proud of the yellow rose. There are some others that saw my roses that I feel sure will give you orders. Yours truly,

Mrs. Addie Cottle.

"The goods were all satisfactory."

\section{E. J. Miller.}

"Received fruit trees $O . K$. and many thanks." JAMES MAXSON.

Oklahoma, June 20, 1927

"Your trees and grapes are doing fine. I only wish $I$ had more of them."

H. G. Frankfother.

Oklahoma, August IO, I927.

"Thos Rogers $\mathcal{E}$ Sons.

Dear Sirs: On June the first a terrific hail storm passed over this part of the country. It killed our entire young orchard, and so we must reset it.

We would like to get your Nursery Book, as I intend to set out the young trees this fall. We gave you a trial order last year, and sure were pleased with the stuff you sent us. Respectfully,

\section{F. P. Krolop.}

Kansas, August 12, 1927.

"Winfield Nurseries.

Dear Sirs: I am writing you to see if you have the American Plum; that is the big yellow plum, and your prices on the trees and also cherry trees. Just a few lines to let you know out of 48 grape vines we got of you last spring only two died. The rest is sure fine. Please let me know about the trees and the best time to set them out, and oblige.

\section{Mrs. Guy Lane.}

Ralph N. Massey of Kansas writes us on August 26, 1927: "I have purchased trees and vines from you the last two years and am glad to say that I have not lost a tree. Surely can recommend your trees. Sure want your 1928 catalogue when it is out. I am going to set about Ioo more trees in the spring."

Mr. M. A. Gould of northern Oklahoma writes u.s on September gth, that he is interested in driving up for some stock. Regarding an order purchased last year he says: "As you know I got a small order last year for a few trees, grapes and flowers, and they have done fine and have made a fine growth this year."

Mr. E. W. McKaughan of Oklahoma writing on September gth has the following to say about our Compass Cherry Plum:

I have some of your cherry plums, one year set out, fruit first year. They sure grow fine. They must be a wonderful fruit when the trees get iarge.

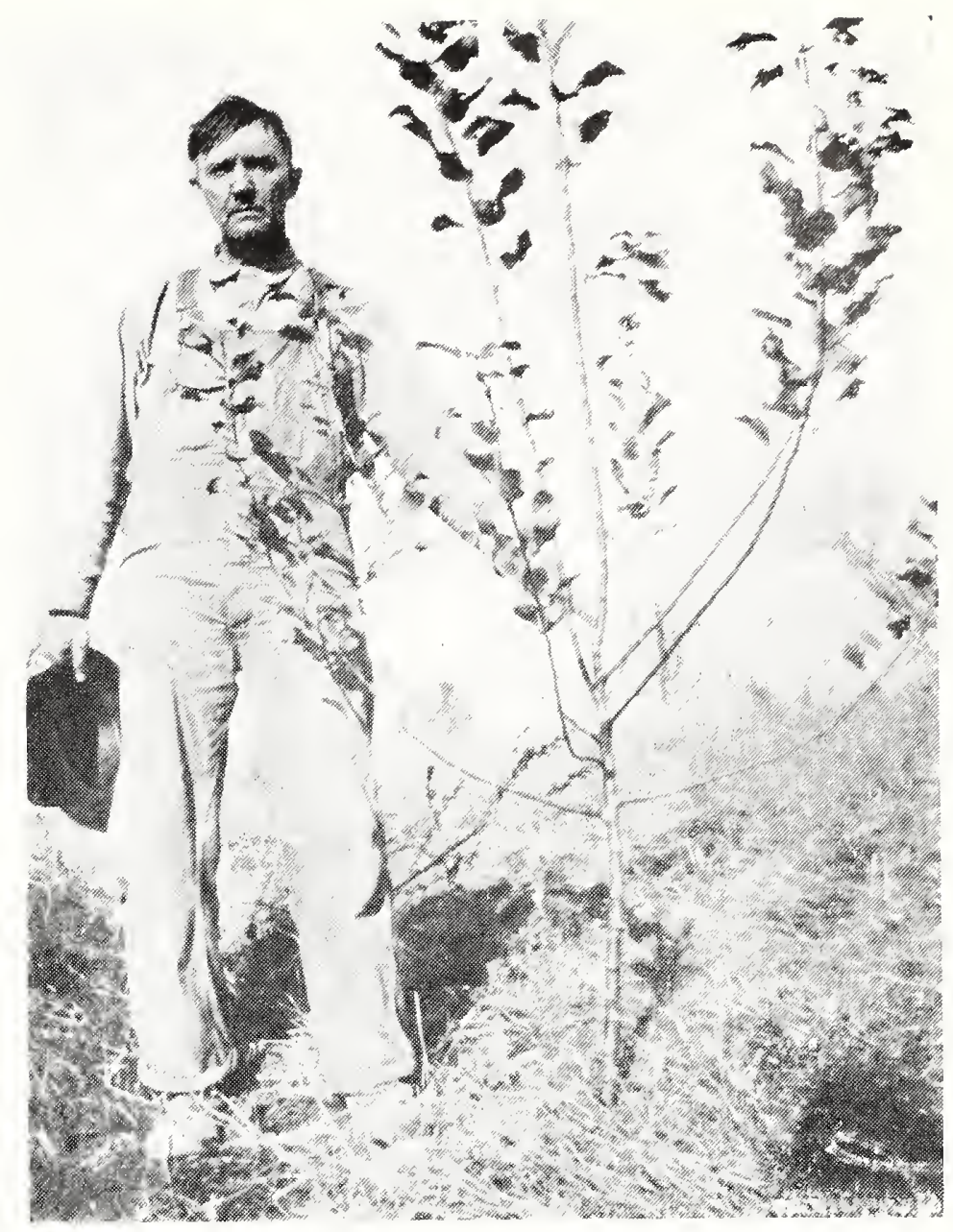

"This picture was made November I5th. This Golden Winesap was set out the Ioth day of last March It has made a growth of 5 feet and Io inches.'

JOHN W. YocUM.

"The Winfleld Nurseries,

December I3, 1927

Messrs. Rogers and Sons.

Dear Sirs: I am inclosing you a photomyself and one of the Golden Winesap apple trees; this is proof of a good root system. I have other apple trees in my orchard that cost me 95 cents each, but they never made such growth. My pears, apricots and peach trees have made equal growth. I am well pleased with all the nursery stock I bought from the Winfield Nurseries. Yours truly,

JOHN W. Yocum.

\section{Five Tons of Grapes From 600 Vines}

Kansas, Sept. 20, 1927.

"The Winfield Nursery Co.

Dear Sirs: Am writing you to ask if it will hurt to trim grape vines now. Have quite a good sized vineyard and would like to trim them this fall if it will not hurt them. They have been out two years this spring. Got 5 tons this year on 600 vines. They were fine as I ever saw raised here. Will send you an order for spring. Yours respectfully,

W. W. HarVEY.

\section{Only Lost 50 Vines Out of 1500 Plants}

Oklahoma, Sept. 29, 1927.

"Mr. Thos. Rogers.

Dear Sir: Please send me catalogue of your nursery stock. I bought I, 50o grapes of you last year and they are doing fine, all but 50 vines. I need about Ioo more to fill in where one died occasionally and am thinking about setting some peach trees. Mr. Enos Willard wants a catalogue.

C. O. Hicks, 


\section{Suggestions to Planters}

Success depends in a large measure on the treatment given the ther it is received by planters. Avoid all unnecessary exposure to the air. As soon as received, it should be heeled in, so that mellow earth will come in contact with the roots. When planting take out but a few at a time. One hour of exposure to hot sun or drying wind is sure death to many trees.

"Heeling in" stock received in the fall. To insure success, rou have only to get the trees before freezing weather and bury them the following manner:

Choose a dry spot, where no water will stand during the winter, with no grass near to invite mice. Dig a trench, throwing out the trees in it, inclined at an angle of 45 degrees or more. Widen the trench, throwing the soil among the roots in position, placing another layer in the trench, reclining the tops on the others, and so another layer in the thench: then water thoroughly. Finish by throwing up more soil until the tips of the trees are fully covered. It is also well to bank up the earth around the sides to insure more thoroagh protection. Care should be taken to fill solid all the interstices among the roots. Too much care in doing this can not be insisted upon, as every root which is not in close contact with the transplanting at the earliest moment possibie to do the work.

Fall planting is advised, however, instead of "heeling in," for

Treatment of Trees That Have Been Frozen in the Packages, Received During Frosty Weather, or After Long Exposure. Place the package, unopened, in a celiar or some such place, cool, but tree from he unpached and either planted or placed in a trench until convenient to plant. Treated thus they will not be injured by the freezing. If dried from long exposure, bury entirely under the ground, soaking well with water, or place in water from 12 to 24 hours, and prune more closely than ordinarily.

Preparation of the Soil.-For fruit trees the soil should $b^{e}$ drs, either natural or made so by thorough drainage, as they will no Tive or thrive on a soil consiantly saturated with stagnant moisture. The soil should be well prepared by plowing at least twice beforehand, using a subsoil piow after the common one at the second
plowing. On new, fresh land, manuring will be unnecessary, but on lands exhausted by cropping, fertilizers must be applied, either by tuming in heavy crops of clover, or well decomposed manure
or compost. To insure a good growt h of fruit trees, lands should e in as good condition as for a crop of wheat, corn or potatoes.

Preparation of the Trees Before Planting. This is on of the most important operations to be performed, and one in which
the most fatal errors are liable to be committed. The object of pruning is twofold: First, to secure a head properly shaped and sufficiently open to the sun and air for the successful ripening of the fruit. Second, to prepare the natural balance between the roots and branches of the trees, that a healthy growth may be Trher

When young trees are removed from the nursery, roots are digging, packing and transportation may be performed, and it becomes necessary that the balance should be preserved by a proper and judicious pruming. This pruning should be adapted to the size and condition of the tree, and at the same time the form should not be forgotten. It should be so close as to enable the roots to supply the demand for sap from the remaining branches, and at the same time, no growth already sec1!red should be wasted.

In both Standard and Dwart Trees, it will be usually found fe rule to cut back, when pruning at transplanting, one-half fhe ends ot the large roots roughly cilt with the spade in digging, always cutting from the bottom of the root with an outward cut. New roots will form, nd the injured parts heal more readily with this attention.

Planting with Spade - The holes should be dug large enougl the first place to receive the roots of the trees without cramping
bending them from their natural position. The tree having been properly pruned, should be held upright and the earth filled in around the roots, the finest and best soil from the surface heing

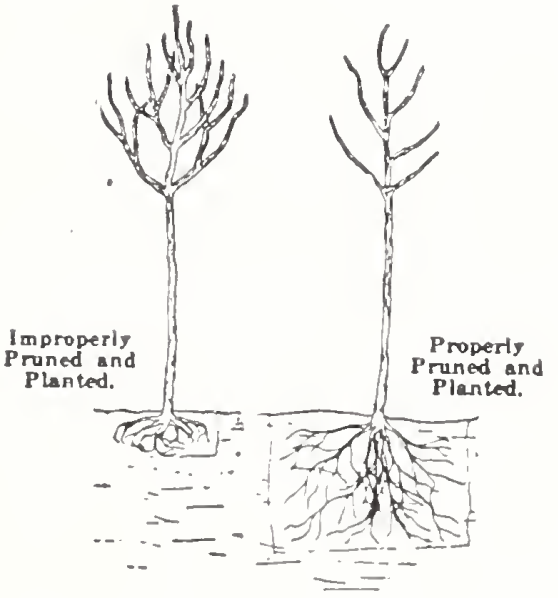

Proper planting and cultivation with correct pruning is the best insurance on an orchard. winds or thrown out by the frost during the winter. It should be removed in the spring. In planting Dwarf trees, the stock on which they are budded should be under ground.

Staking. - If trees are tall or in exposed situations, they should Staks to prevent injury from the action of the wind. Mulching - This is properly done by placing a layer of coarse manure or litter from three to six inches deep about the tree, extending one to two feet further in each direction than the roots This keeps the ground moist and of equal temperature, rendering watering unnecessary, and is in all respects preferable to it. Trees properly mulched are more certain to live and make much greater rowth than those which are not so treated.

Cultivation After Planting.-Here is the grand opportunity or the success of the skillful fruit grower. It is not enough for him that his trees are of the choicest sorts, selected with regard to the climate and adaptation to the uses for which they are designed; that they are properly pruned and planted in dry, mellow soil, thoronghly enriched and prepared for their reception; protected from the winds by properly staking, and that they are in perfect shape and thriftiness. He knows very well that all this may be properly and well done, at great expense, and without further care be followed by an entire failure, so he watches their growth and delo not find safe lodgment among the branches; or the borer cut about them or the cattle obtain access to them by neglected gates or fence, and break down the branches. He is well repaid, for they thrive and grow rapidly; the shoots are vigorous: the bark clean and smooth, and soon a most abundant crop of superior fruit testifies o his wisdom and care.

Pruning.--Pruning after the first year should be varied according to the purpose of the planter and the variety of the tree. tended the future head should be, and the cutting off of large limbs may not in the future be necessary. The removal of large branches should be aroided in all cases whenever it is possible to do so, as decay is liable to commence at the point of separation and extend into the trunk: whenever it is done the wound should be carefully pared smooth and a coating of paint or grafting wax applied to protect the action of the weather. After the removal of lower branches until the head has reached the desired height, the only pruning needed is to remove such branches as are crossing and interfering with each other, and keep the heads in a symmetrical shape and well open to the sun and air. Trees should receive proper shape by judicious pruning and attention early in the spring of each year, while they are young, and very little pruning will be necessary after-

Grape Vines require a dry, mellow, well-drained soil, deeply worked and well enriched, with a warm, sunny exposure. In planting, give the roots plenty of room and settle soil firmly about them.
All newly planted vines should be cut back to 2 to 3 buds or eves as soon as planted. Two sprouts or canes should be allowed to grow the following summer and should be carefully tied to stakes to keep them from becoming broken in cultivation, winds, etc. The to the lower wire of the trellis, which should be put up the following fall or winter after planting.

For the subsequent pruning of vines as well as trees, planters would do well to consult some practical work on the subject.

Berries should have a strong soil and be kept under constant cultivation. NIulching is of special value. Raspberries and Blackpinched off when three feet high. Strawberries should be mulched late in the fall: uncover the crowns early in spring; remove mulch ter fruiting and spade in light dressing of manure.

Currants and Gooseberries need heary mulching and prun, so that new wood will have room to grow.

Roses should have a deep, rich, well-drained soil, and should be severely pruned every spring before the buds start, cutting back all the last growth to three or four buds, except climbing roses, which may be first allowed to partly cover the space desired. Old should be placed around the stems of the plants and spaded into the ground in the following spring. filling every space and bringing every root fully in contact with it. When the hole has been half filled, pour in a pail o two of water; let this planting by placing soi enough about the trees to raise the surface somewhat higher than else carefully down with the foot. Care must be taken against planting too deep; against planting too deep; about the tree it should stand at the same height as when in the nursery When set in autumn, it
is well to raise a mound of earth about the trees foot or more in height. This will keep them from being swayed by the

\section{DISTANCES FOR PLANTING.}

Standard Apples.

Standard Pears.

Dwarf Pears.

Standard Cherries

Plums, Peaches, Apricots.

Currants, Gooseberries, Raspberries, Rhubarb

Quince and Grapes.

Asparagus.

30 feet a part 25 feet apart 10 feet apart 15 feet apart 15 feet apart 4 feet apart 10 feet apart

Mr. J. C. Searcy of western Kansas visited our nursery last summer and placed an order for 400 cherry trees. Receiving the trees November I 3 th he writes: "I received the trees today. They reached me in splendid condition and they are a fine lot of trees. Many thanks for the great care you have given them. I am sending check in payment for the trees.

Mr. A. W. McGinnis urites on November 21 st: " Mr. Rogers, the trees reached here all right in good shape and were fine. Everybody seemed pleased with them." 


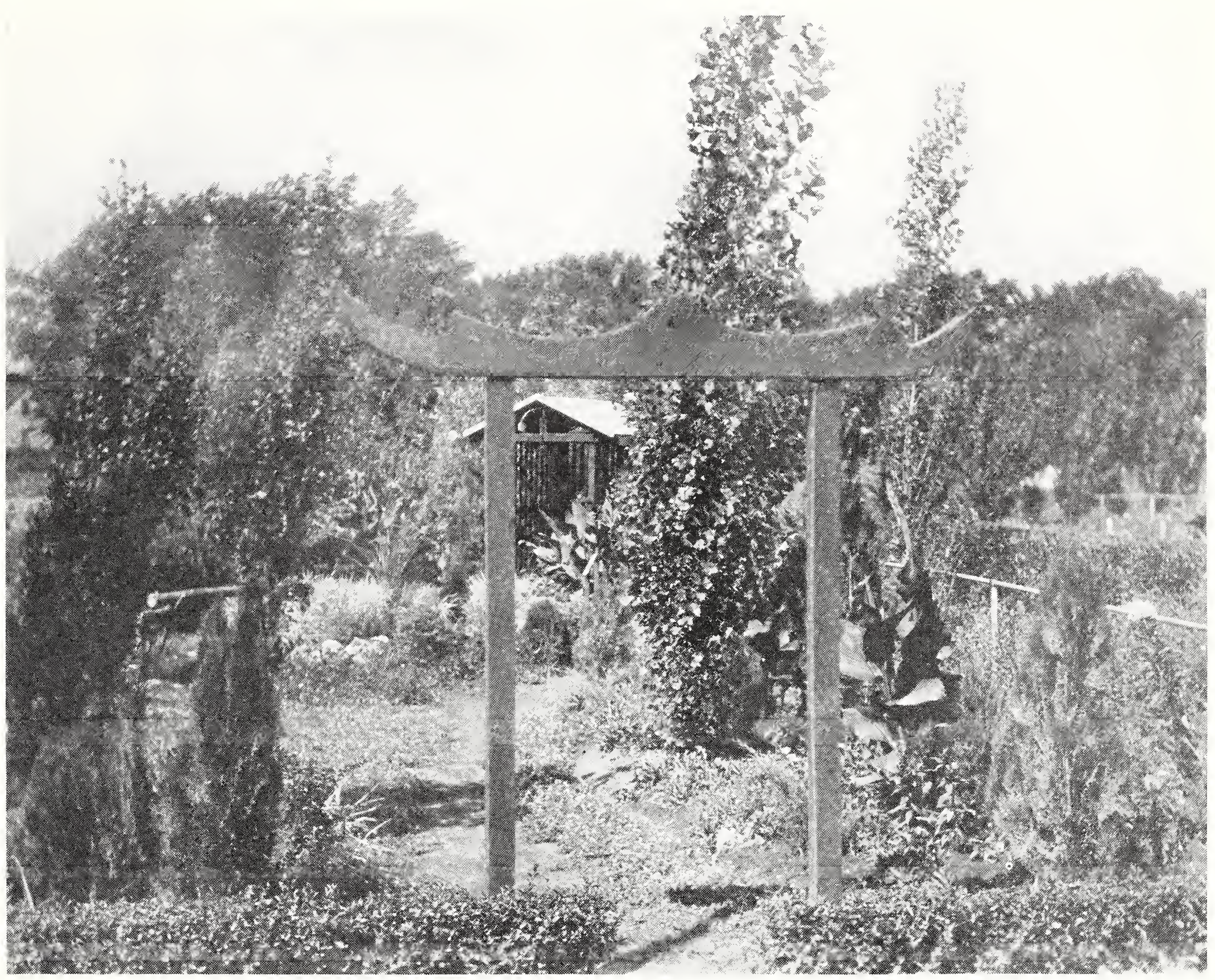

\section{A View of A Garden On Our Display Grounds Landscaped and Planted in Spring of 1927}

Our Display Grounds consist of a block of ground on South Main Street on which are planted all kinds of ornamental trees and plants. Stop and see the different kinds of shrubs, roses and perennials in bloom, whenever you are in Winfield. Visitors are always welcome and extended every courtesy.

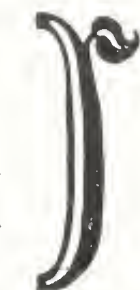

\section{Roses}

The Rose is acknowledged Queen of the Garden; in color and fragrance, in refinement of texture and form, in the great range of variety, our Rose is pre-eminent as the loveliest of flowers. The varieties we grow are the best in each class; not all the good ones - because there are thousands of varieties in cultivation - but no better list could be made up in any equal number of varieties. Our selection has had in mind to offer Roses that are distinct, that possess quality of individual bloom, abundant yield and have the hardiness required for our climate. Our Roses are strong, healthy, two-year, field-grown plants.

These are all hardy varieties that bloom in June, usually again in the autumn and of ten through the summer with good rainfall. A few are as constantly in bloom as the Hybrid Teas and might properly be listed among the monthly-blooming roses.

AMERICAN BEAUTY - Deep, rich pink shaded with red and petals distinctly veined; of large size, full and fragrant; grown in immense quantities by the florists and, while not so good out of doors, is a popular garden variety. While the outdoor blooms

have the same color and size of hothouse specimens, they are not borne on long stems like the latter; that must not be expected.

FRAU KARL DRUSCHKI-Known also as Snowqueen and White American Beauty. Pure white, exquistely formed in bud and open flower; blooming most abundantly and considered by everybody as the best white rose.

GENERAL JACQUEMINOT-One of our great favorites; scarlet-crimson; large; especially showy and fragrant.

PAUL NEYRON-The largest rose of all. Blossoms of clear pink shading to rose. Flowers are well shaped, double

and very fragrant. Plant is erect in habit and a strong, heavy grower, blooming repeatedly during the season. Early in the spring, Paul

Neyron roses are often mistaken for Peony blooms, when seen from a distance.

ULRICH BRUNNER-A bright cherry-red rose of striking beauty. The flowers are unusually large. Hardy and vigorous in growth, resisting mildew. 
See Price List for

Special Prices
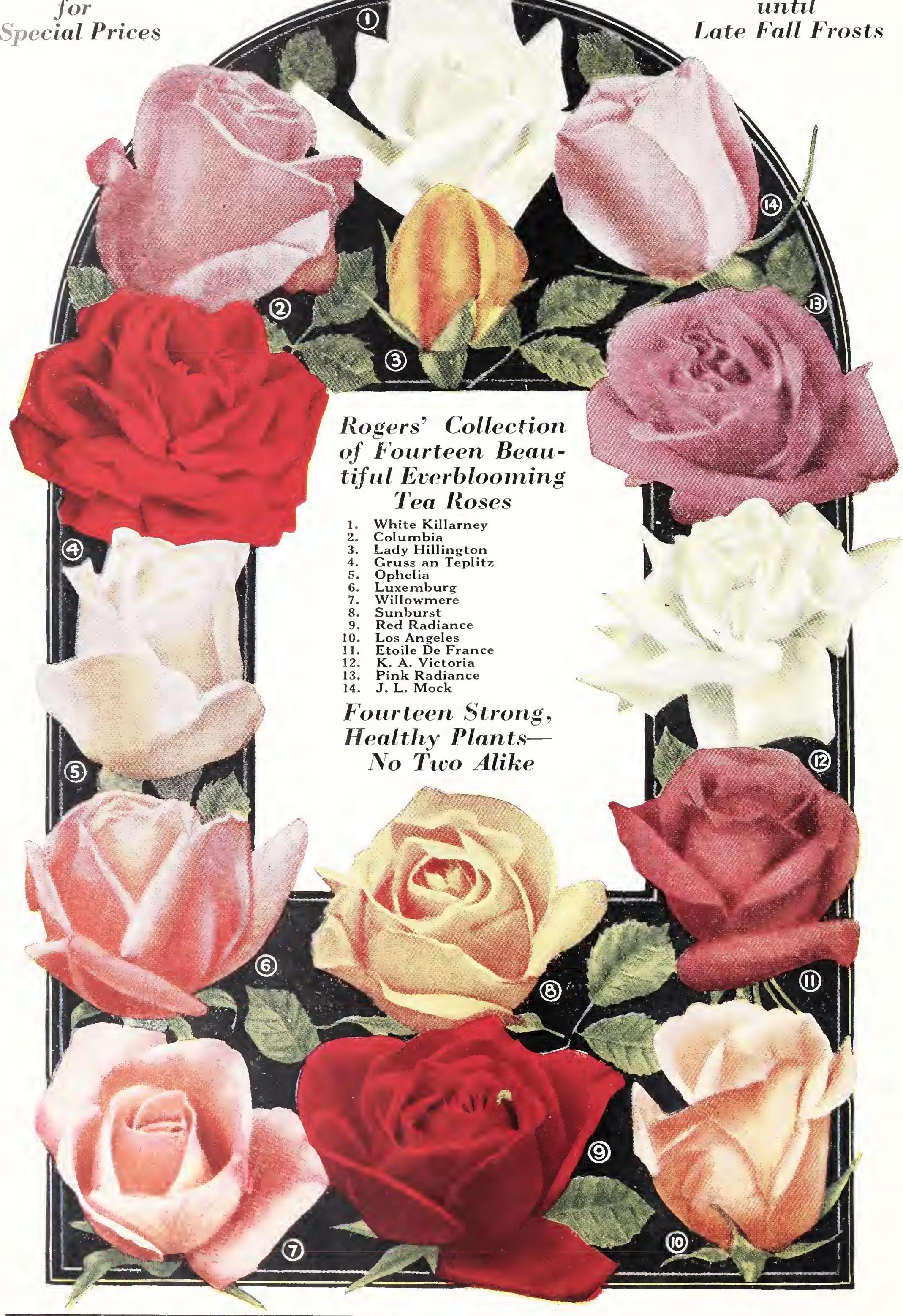

Blooms from May until

Late Fall Frosts
Rogers' Collection of Fourteen Beautiful Everblooming Tea Roses

1. White Killarney

2. Columbia

4. Lady Hillington

5. Ophelia

6. Luxe mburg

7. Willowmere

8. Sunburst
9. Red Radiance

10. Los Angeles

11. Etoile De France

12. K. A. Victoria

13. Pink Radiance

trong, ealthy Plants-

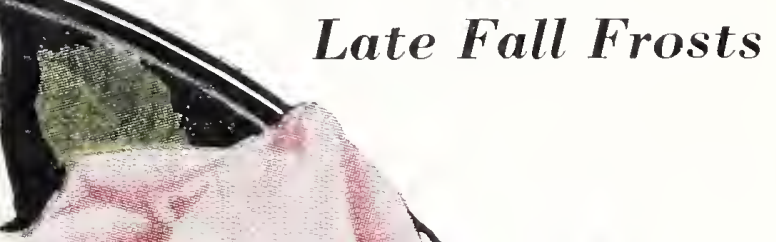




\section{Hybrid Teas-Monthly Everblooming Roses}

This type of Roses thrives best in clay loam well enriched with rotted manure. They should have an open, airy situation unshaded by trees or buildings. Work up the soil thoroughly to a depth of 12 to 15 inches, and besides this, soak the beds occasionally with weak manure water. Plant your roses in solid beds. You should have at least a dozen plants to make a showing. Dormant plants set in the spring should be planted early, before growth is started. No plant suffers more by being planted late than does the rose. Raised mostly for their flowers, it is necessary to give roses that culture best adapted to produce this result. A very rich soil is of first importance.

All roses should be clipped back closely at planting, and each spring remove at least two-thirds of the previous year's growth. In the ever-blooming class, remove even more. As soon as severe freezing weather sets in, raise the earth around the plant 3 or 4 inches, with leaves, straw or mellow soil. It is very important to keep the plants vigorous and free from diseases and insects.

The following list of our Roses will start to bloom yet this spring and will continue blooming until the late frosts: COLUMBIA-An American rose growing as perfectly in the garden as the hothouse. It is a bright pink, which deepens but does not fade as the flowers age. The large, double blooms outlast nearly all others a nd being on long, almost thornless stems, a re desirable as cut flowers. The plant is strong and sturdy.

ETOILE DE FRANCE-Intense red. The buds are perfectly shaped and the fully open flowers are equally perfect, remaining to the last, full and double.

FRANCIS SCOTT KEY-Large crimson buds and blooms of good form. Very double; slightly fragrant, good foliage.

GRUSS AN TEPLITZ - A brilliant crimson Rose changing to a fiery red. One of the freest bloomers of them all, and hardy. The flowers open loosely, but despite this, every Rose lover should have Gruss an Tephitz in his garden. For fragrance there is no other Rose to compare with it.

HOOSIER BEAUTY_-Scarlet red, long slender buds; flowers full and fine.

J. L. MOCK - The petals are a light silvery-pink inside, and a deep pink outside. Sometimes called a glorified La France, but is a stronger grower, blooming constantly.

KAISERIN AUGUSTA VICTORIA-One of the most popular of white roses. Large, pointed buds, and very large, full, double flowers of a delicate creamy-white, with a delightful fragrance.

KILLARNEY, PINK (The Irish Rose) - The buds are especially fine, delicate and shapely. Blooms profusely and constantly. Its only fault is that the blooms are more single than double when fully open; but it is one of the very best roses for the garden.

KILLARNEY, WHITE - A pure white sport of the popular Irish rose. It is identical in appearance with its parent, only it is pure white.

LA FRANCE - Probably one of the best known roses; very full and double blooms of delicate, silvery-pink and deliciously fragrant. Severe pruning is needed to produce the best in blooms.

LOS ANGELES - One of the most notable garden roses and the first American variety to receive the grand prize at the Bagatelle Garden (Paris). Its color is a luminous flame-pink, toned coral, shaded translucent gold at base of petals. An upright, sturdy grower, bearing perfect fragrant flowers on strong stems. Desirable for every garden. LUXEMBURG-This is one of the top ranking yellow Hybrid Tea Roses. With long pointed buds of exquisite texture and rich bronze-yellow colorings, they are bound to be the attraction wherever blooming. The plant is a strong, vigorous grower, and produces these striking flowers in great abundance. A distinctive type that should have a place in every rose bed.

LADY HILLINGTON-Another exquisite Rose, with long pointed buds. 'The blossoms open up very double, and are of a beautiful deep apricot-yellow. An excellent bloomer and in every way a fine Rose. You will be proud of it in your rose garden.

MADAME CAROLINE TESTOUT - The rose that made Portland, Oregon, streets famous. Extra large, fragrant blooms of brilliant pink with darker center. Edges of petals tinged with soft carmine-pink. Very free-blooming and hardy.

MADAM COCHET-A valuable pink bedding Rose, with large flowers on long, straight stems. A deep rosy-pink, inner-side of petals silvery-rose.

METEOR-Dark velvety crimson, shaded maroon. A good garden rose.

MY MARYLAND_Glowing. intense pink, which lightens up beautifully as the flower expands.

OPHELIA-Outdoors as well as in the greenhouse, this rose has taken a high rank. Its blooms are large size, full and perfect in form and appearance, and of attractive light salmon shading to light yellow. The plant is vigorous, reliab!e and persistent.

RADIANCE-Brilliant, rosy-carmire. The buds are perfect and while the open flowers are not so large nor so full as those of some other varieties that produce only a few extra large blooms, nevertheless Radiance is today one of the most satisfactory everblooming pink roses, because it is one of the hardiest and always abundantly in bloom.

RED RADIANCE - Similar in every respect to Radiance, of which it is a sport, differing only in color, which is a rich red that does not fade with age.

SUNBURST - This magnificent giant vellow Rose is a fine forcer and stands head and shoulders above all others of its color and ranks with American Beauty and the Killarneys in value and grandeur. The color is orange-copper or golden-orange and golden-yellow; edge of petals lighter; all intense shades, extremely brilliant in effect. Some call the color cadmium-vellow; anyhow it is the yellowest of all Roses which we grow in our nurseries.

WILLOWMERE-Color is a rich shrimp-pink, shaded yellow in the center and toning to carmine-pink towards the edges of the petals. Long carmine-coral buds on long, stout stalks. Vigorous growth and erect branching habits.

\section{Our Roses Are Satisfactory}

"Thos. Rogers E Sons,

Oklahoma, Nov, 26, 1027

Winfield, Kansas.

Gentlemen: For the past two years I have bought roses from you and am glad to report that plants have been satisfactory. Both last year and the year before I ordered plants not only for my own garden, but some for some of my friends, and I am sending you an order today for some roses and trees for myself, and also some orders for my friends, which wish you to pack separately, and label with the names of the parties for whom I am ordering, so that I can pass them to on the purchasers without breaking their packages.

TERRY MARLIN 


\section{Climbing Roses}

You will find our Climbing Roses to be alrays satisfactory. In the first place, those recommended here are all perfectly hardy; they do not need much protection in the winter and they require little pruning or other attention. They make wonderful hedges and combine beauty with utility; planted along the back fence, clambering over the porch, screening a window, and especially when covering an old stump or other unsightly object, they add to usefulness a beauty of color and fragrance not equalled by any other clinging plants. And while most of the Roses in this class bloom only in the spring, ther cover themselves with masses of beauty at that time. We do not grow any of the tender everblooming monthly climbing roses, as they are not hardy this far north.

CLIMBING AMERICAN BEAUTY-A seed-

ling from American Beauty with Michuriana

and Tea blood in its veins. Same color, size and fragrance as American Beauty, with the addition of the climbing habit, good foliage and better blooming qualities. One plant of this new rose will produce twenty times as many flowers in June as the old American Beauty, besides blooming occasionally during the summer; blooming 3 to $t$ inches across: has proved perfectly hardy and stands heat and drouth as well as any rose in our collection.

AMERICAN PILLAR - Immense clusters of single bright crimson flowers, with clear white eye, on long, strong stems. Vigorous climler.

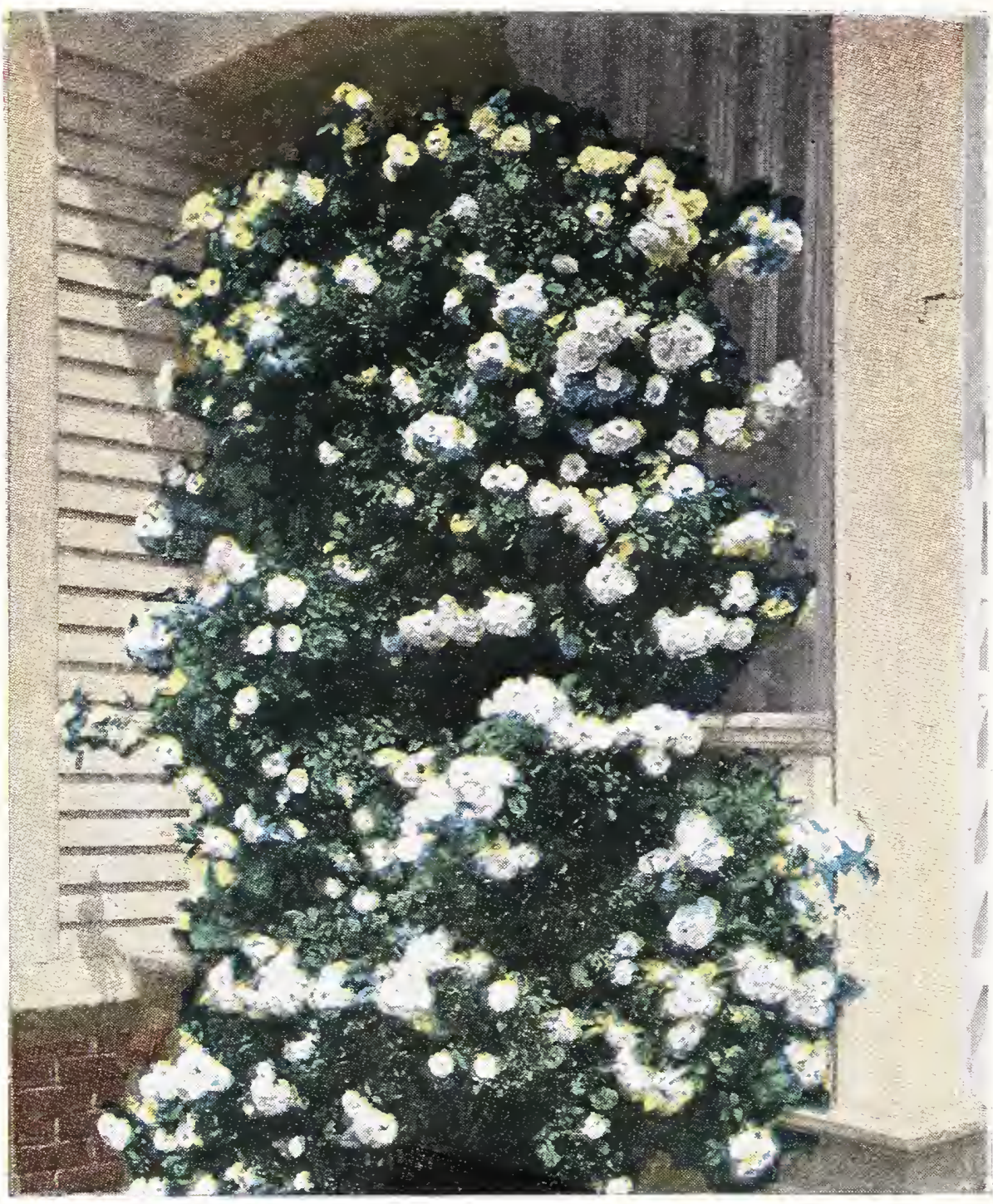

Silver Moon

DR. VAN FLEET - A beautiful flesh-pink, with individual blooms four inches in diameter. Much like hybrid teas in form and color, with a pleasing fragrance. A long-stemmed, valuable cutting rose. This is the best pink climber. Absolutely hardy, making canes of twelve or fifteen feet in a favorable season.

GARDENIA - Has lovely golden-yellow buds that open to almost white when fully expanded; most dependable yellow climbing rose. Tery kardy.

SILVER MOON - To the rose lover who has not enjoyed Silver Moon, a delightful experience is in store in contemplating this extraordinary vigorous climber, decorative all through the growing season by reason of its great canes and deep, rich foliage, but literally a wonder at bloom-time for its long, well-shaped buds of faint yellow which open into immense pure white flowers, often reaching four inches or more in diameter. These blooms are semi-double and with very distinctly curled and curved center petals which surround the bright yellow and add piquancy to the whole effect. An indispensable white rose and if we find your order does not contain our Silver

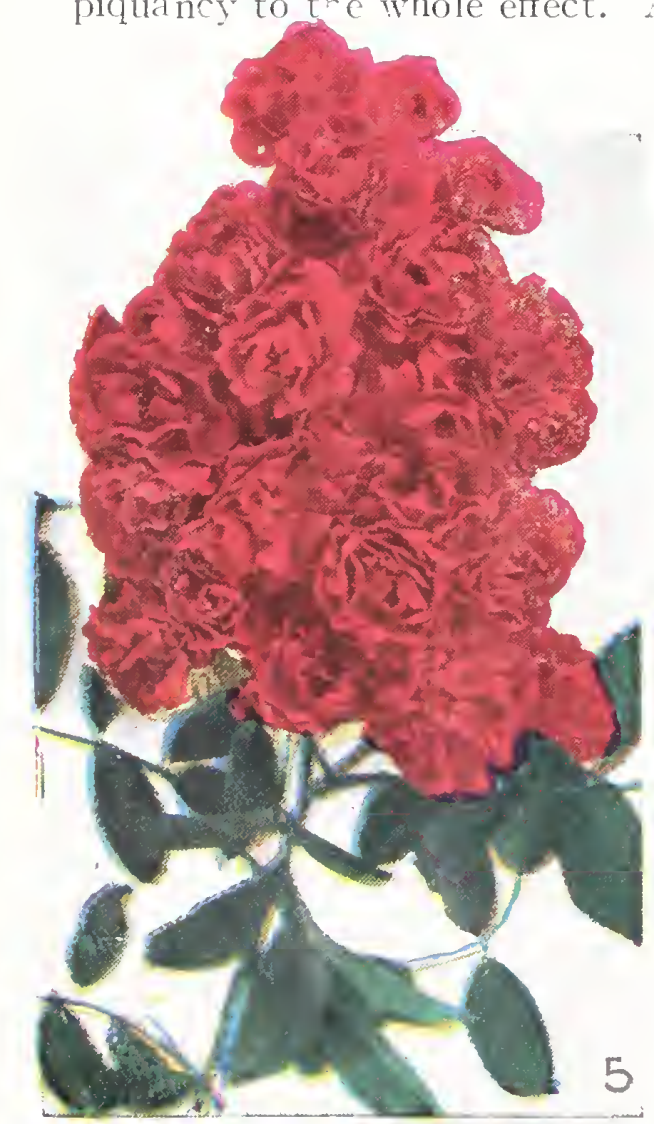

Moon, we will be tempted to include it anyway.

PAUL'S SCARLET--Called by most growers the "Reddest Rcse that Grows" and is by far t'e finest Climbing Rose in existence. It verifies its name in its intense scarlet colorings, never fading out in the hot rays of the sun, as other Ramblers do, but holding the vivid brilliant red from the first peep of the bud until the petais fall. Blossoms are nearly once again as large as the Crimson Rambler, semi-double, and stand on the vine in good condition for an unusually long time. Hardy and a very vigorous grower. No other Rose will give the same effect and it is essential for your garden. Tom saw this Beautiful Rose win the first prize of its class at the National Flower Show in Rochester, New York, in 1924.

MARY WALLACE-Large, glossy foliage; blooming with great freedom in spring and bearing a considerable number of fine buds in summer and fall. Flowers very large, well formed, semi-double, of a bright clear rose-pink, with salmon base.

CRIMSON BABY RAMBLER - One of the best hardy bedding roses; vigorous, and grows 18 to 24 inches high; flowers are borne in clusters of 20 or more to the cluster. Color a bright crimson.

"Just a line to let you know that we got the trees all O.K. and many thanks for the rose bush. Now inclosed you will find my check to pay for two Japan Blood Duarf Peaches to send to Mr. Frank Young, San Diego, California." 


\section{Climbing Vines}

Vines fill an important place in beatifying the home. Shady arbors and verandas are cool retreats in summer. A few vines on the wall, clambering up an occasional tree or covering an old stump, relieve the stiff effect of shrubs and formal plants and a suggestion of ease and grace is arlderl to the picture. As many vines-particularly Clematis-are planted by trellises and close to the wall where the soil is poc $r$ and dry, ample holes should be dug and filled with good topsoil before planting.

\section{Matrimony Vine}

A vigorous climber, branching freely and covered with brightly purple star-shaped flowers, succeeded by brilliant scarlet berries.

\section{Trumpet Vine}

Flowers large, trumpet-shaped, orange red in summer. For arbors, rocks, trees, etc.

\section{Madeira Vine}

A beautiful rapid growing vine with dense foliage. Grows well anywhere, but succeerls best in sunny, well sheltered location.

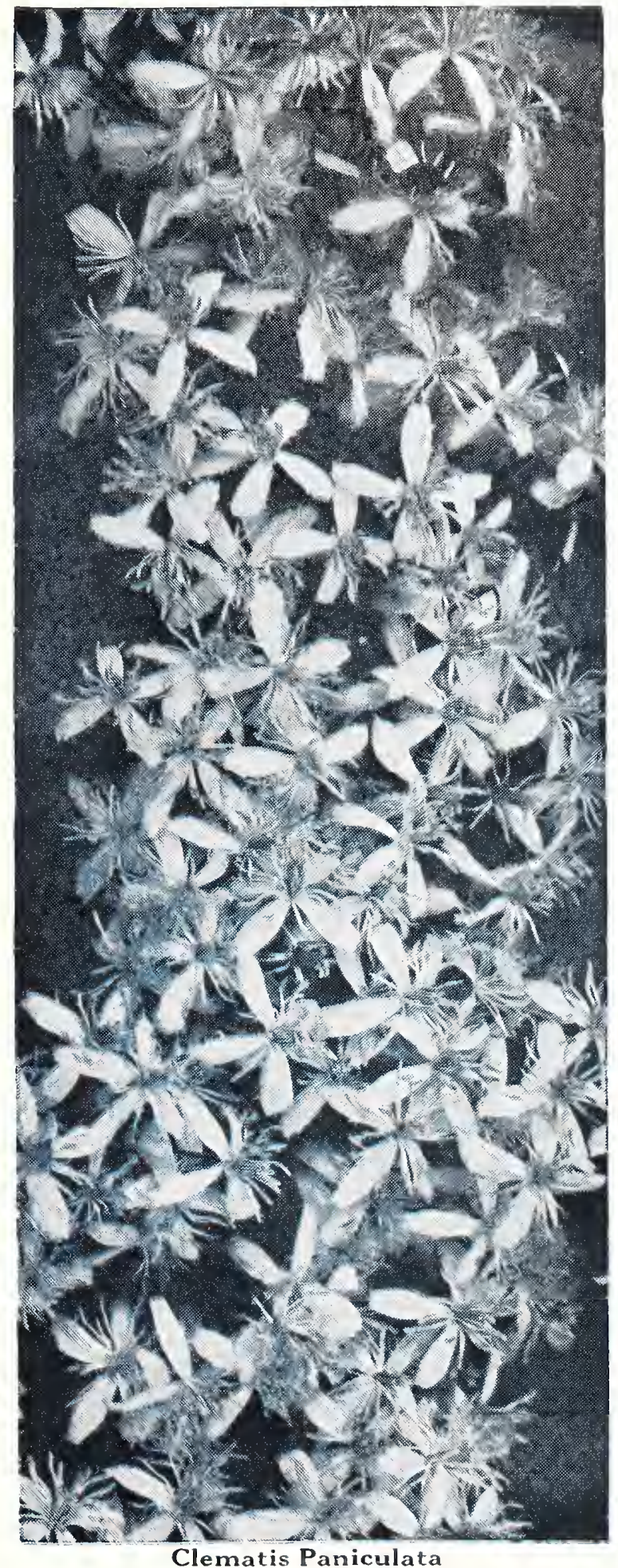

\section{Wistaria}

The Wistaria is one of the most decorative of vines, and for porch decoration without too much shade it has no superior. The long twining branches hear sprays of foliage, while its charming flowers sway with every passing breeze.

Purple Wistaria - A beautiful climber of very rapid growth, producing long, pendulous clusters of pale blue flowers in June and sometimes again in the fall; is perfectly hardy and one of the most superb climbing vines ever introduced.

White Wistaria-An attractive and strong grower with a large number of hanging pea-shaped, white flowers.

\section{Honeysuckles}

All are rampant growers, forming great masses of vines that require sunlight and fail to form leaves in the shade. All are fragrant. Hall's Japan Honeysuckle - A strong, vigorous, almost evergreen sort, with pure white flowers, changing to yellow. Covered with fragrant flowers from July to December. Holds its leaves till January. The best bloomer of all.

Monthly Fragrant Honeysuckle-Blooms all summer; red and yellow; fragrant.

Scarlet Trumpet Honeysuckle-Strong, rapid grower, producing scarlet inodorous flowers.

\section{Clematis}

This is one of the most attractive and effective of the hardy flowering climbing vines. Especially adaptable for covering trellises, fences, walls, and pillars.

Henryii-Flowers large and creamy white, from six to eight sepals. Jackmani-Covered from July to October with a dense foliage of purple flowers. A strong grower and a popular variety, but very hard to get started.

Paniculata-Flowers are medium in size, pure white, borne in immense sheets, and of a most delicious and penetrating fragrance.

\section{Ivy Vines}

Boston Ivy-Leaves small and dainty, ivy-like in form. By over lapping each other they form a dense sheet of green. The plant requires some protection the first winter until it becomes established. Will climb any kind of a wall.

American Ivy-(Virginia Creeper) - A very rapid growing vine, covered with large, heavy leaves affording shade; of great beauty when changing to scarlet in autumn. The best climber to grow over porches, rocks, or fences.

Engelmann's Ivy-A rapid growing vine of the Virginia Creeper family but having characteristics of its own. Leaves are smaller and many more of them than those of the Creeper. Foliage of deep green. Will cling only to a rough surface, such as brick or stone. 


\section{Shrubs}

People generally are appreciating more the permanent value and beauty of shrubs. The charm and grace they lend to home grounds is invaluable, and if judicious selection is made, it is possible to have a continuous succession of bloom from early in April to the day's when the frost again nips the flowers of the very latest to bloom.

In many cases it would be better to plant shrubs in groups of several to one side of the lawn instead of following the method of planting one in a certain place and spoiling the effect of the open lawn. In most cases, three, sis, eight, or twelre of one variety should be used in a particular grouping. Several such groupings make an excellent border or foundation planting.

Our shrubs are well dereloped sizes. The tall-growing varieties will run from three to four feet in height. The slower growing or dwarf types will run two feet and up. The shrubs are specimen clumps, composed of several canes, and in group plantings will give you an immediate effect. Our shrubs will bloom the summer following planting. Don't let cheaper prices persuade you to buy the small and light-sized shrubs elsewhere-it will take several years for them to make any kind of a showing.

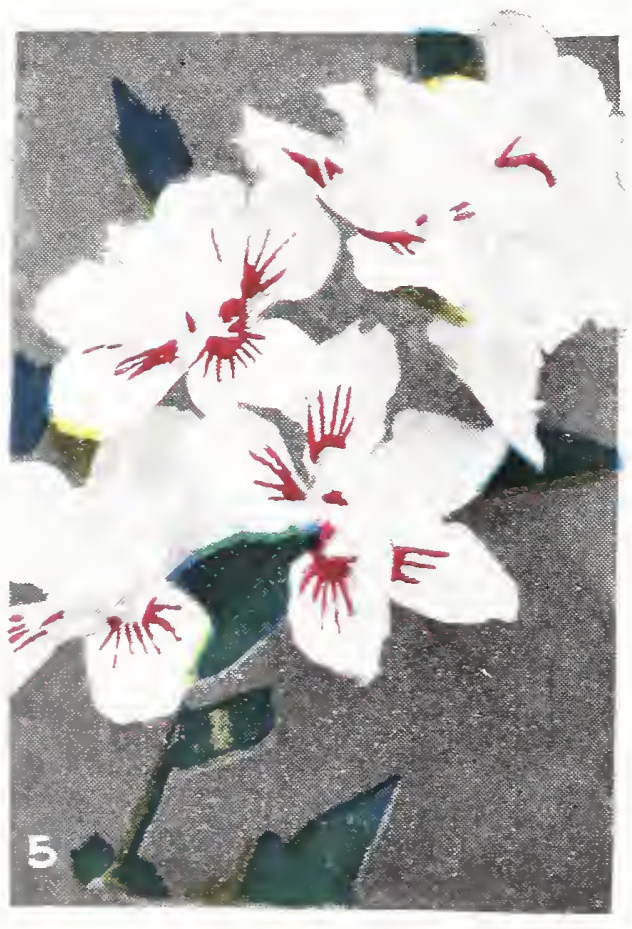

Althea: Variegated
ALTHEA OR ROSE OF SHARON-The Altheas are fine, free-growing. flowering shrubs of rery easy cultivation. Desirable on account of flowering in August and September. when nearly every other shrub or tree is out of bloom. They are of good size, many colored, and attractive. Perfectly hardy and can be had in various colors if desired. They require some pruning each spring. We can supply Altheas in blue, pink. purple, red, white and variegated.

BUTTERFLY BUSH (Summer Lilac) - I most beautiful shrub and one that should be in every garden. A splendid shrub for park planting. It makes large shrubs for park planting. It makes large shrubs even from smail plants the first season. Single plants will often have 50 or more flower spikes the first year. The second year after planting it generally begins to bloom in June and continues throughout the summer until frost nips it. The flowers are froduced on long, graceful stems that terminate in tapering panicles or on flower heads frequently 10 inches long This admirable shrub should be classed as semi-herbaceous, as it sometimes freezes back to the ground in severe winters, but comes up again from the roots.

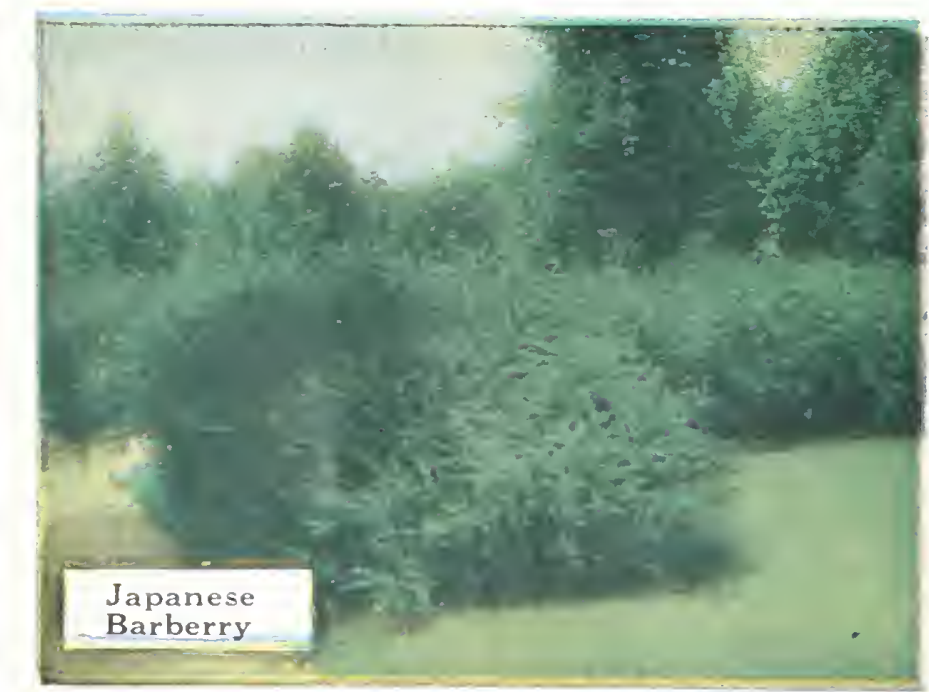

Japanese Barberry

\section{A Splendid All-Round Shrub}

One of the most raluable all-purpose shrubs, will grow in almost any soil, in sum or shade, dense-growing, three to fire feet: perfectly hardy. The leares are small, green in early spring and summer, scarlet in fall and into winter. The twigs are thorny and covered with scarlet berries in fall and winter. One of the best shrubs to plant against foundation of house or porch, in front of taller shrubs, and makes a nice looking low hedge.

On November 28th after receiving his order Mr. Martin Klemme says: "Mr. Rogers, I received the shipment of fruit trees I ordered. They are nice trees. I am well pleased with them. 


\section{Shrubs-Continued}

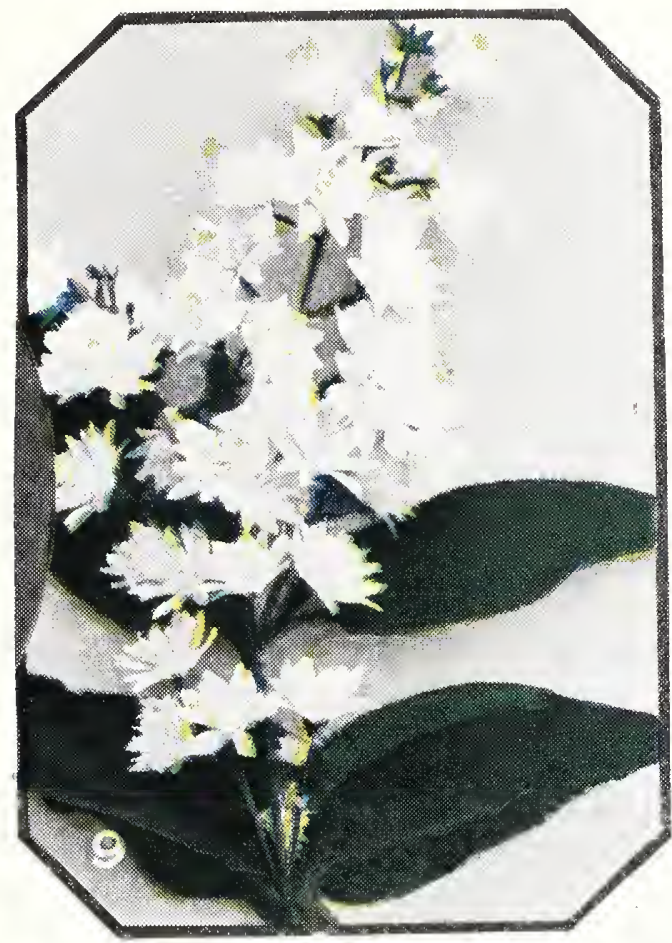

Deutzia-Pride of Rochester
DEUTZIA - Showy Japanese shrubs of the highest ornamental merit, and adapted to all good soils. Their clean foliage, upright, dense growth, freeflowering nature, render them especially valuable.

Gracillis (Dwarf)-A low bush, three or four feet in diameter, flowers pure white and graceful. One of the prettiest and most popular small shrubs. Fine for winter forcing.

Pride of Rochester-A fine double variety rather early. Flowers pink in bud, white when fully expanded.

DESMODIUM - Valuable for great profusion of pea-shaped, rosepurple flowers in September to late October. Grows to three feet, drooping very gracefully, being loaded down with blooms. The top dies down in the winter, useful in shrub masses or borders.

FORSYTHIA (Golden Bell) - The Forsythias are the first shrubs to bloom in early spring, the small, yellow flowers covering the branches before the tardy leaves appear. They grow to about seven or eight feet.

Suspensa-A drooping variety that makes a desirable bush when planted alone or can be made to arch trellises, etc.

Fortuni- Of slightly drooping habit, with flowers large for the type.

Viridissima-Deep yellow flowers and very dark green wood and foliage; upright in growth.

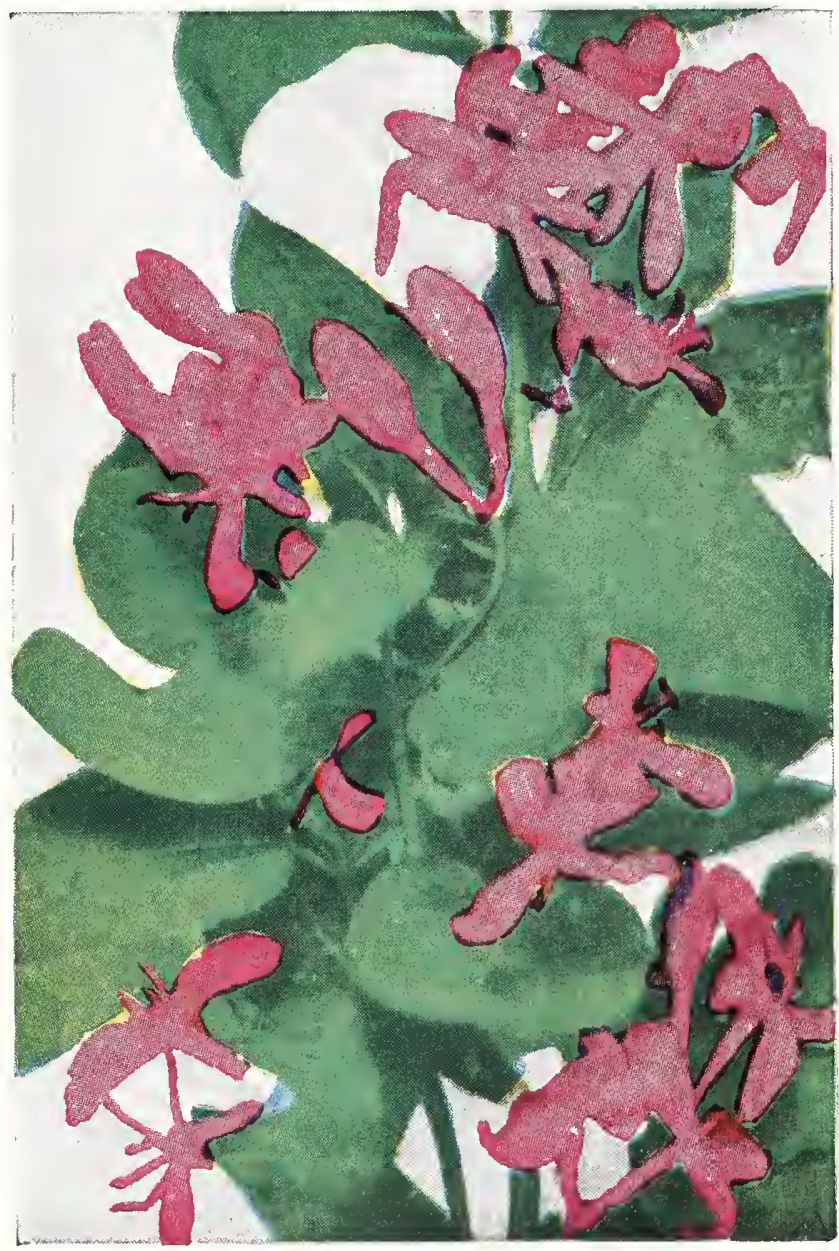

Honeysuckle-Pink Tartarian

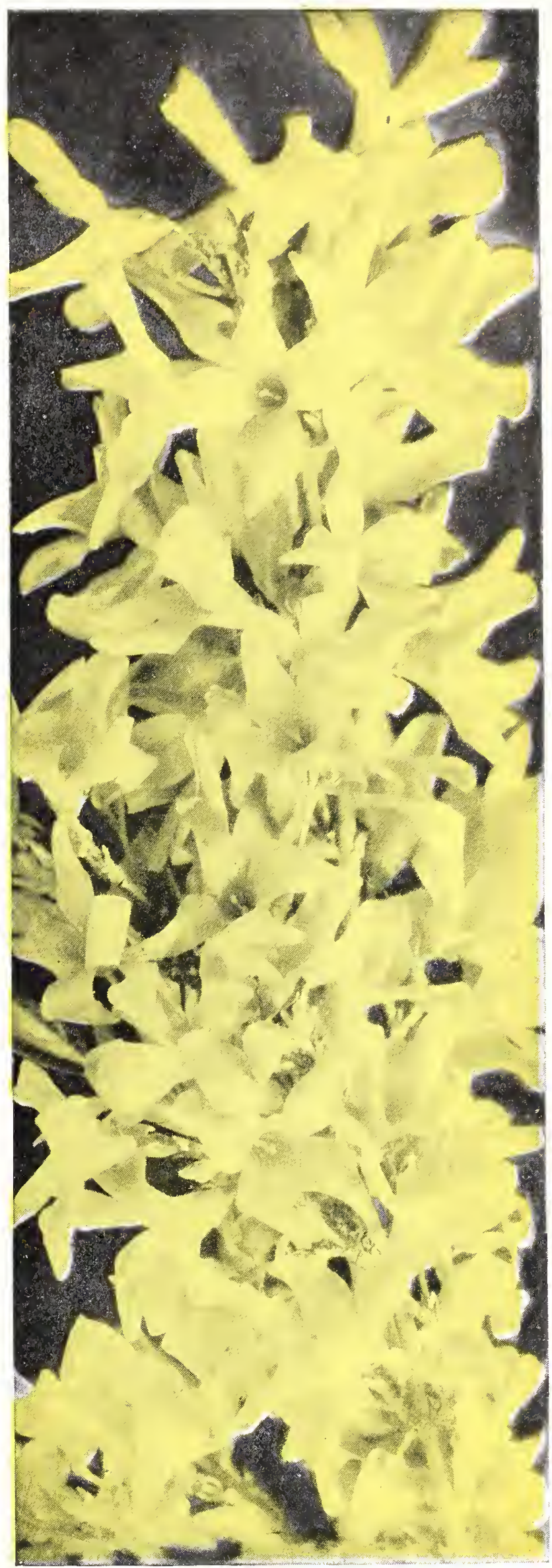

Forsythia-Golden Bell

BUSH HONEYSUCKLES-Upright bushes, entirely distinct from climbing honeysuckles, making a compact growth of eight to ten feet at maturity and bearing white, pink, or red sweetscented flowers followed by colored fruits.

Pink Tartarian Honeysuckle-Pink flowers that make a lovely contrast with the foliage.

Red Tartarian Honeysuckle-Blooms early in the spring. The flowers are a beautif ul bright red.

White Tartarian Honeysuckle-Produces creamy-white, fragrant flowers in May and June.

"Small bill of trees reached me in very satisfactory condition and have them set.

W. F. COULSON 


\section{Strubs-Continued}

HYDRANGEA (Arborescens Sterilis)—Commonly called "Hills f Snow." This grand American shrub deserves increased attention. Handsome foliage and showy, snow-white, ball-shaped clusters of flowers make it a most conspicuous object wherever grown. Blooms the greater part of summer, does its best under all circumstances, is perfectly hardy and increases in size and beauty from vear to year. Does best in moist, fertile soil with full exposure to the sun. Thrires most anywere and does well eren if neglected.

HYDRANGEA PANICULATA GRANDIFLORA - A beautiful tall shrub with leaves of bright, shiny green. The flowers are borne in huge panicles from $\&$ to 12 inches long, light pink, changing to brown later in the fall; blooms in August and September. GOLDEN ELDER-The white, flat-topped panicles of bloom appear in the early summer; but the golden-yellow color of the leares is the chief attraction, making the plant conspicuous among the darker green.

JAPAN QUINCE - The bright scarlet blooms appear the first thing in the spring before the leares are out, giving warmth and color to the garden at just the right time.

KERRIA JAPONICA-Handsome and graceful with pointed leaves and long branches from the ground, covered, in June, with bright yellow flowers which continue throughout the summer.

LILACS-The Lilac is the popular and universal flower. They are heautiful and indispensable in erery collection. Lilacs usually attain a height of 6 to 8 feet and make excellent screens for unsightly fences as well as a hedge for property lines or backgrounds for the shrubbery borcler

Common Purple is the well-known purple fragrant variety.

White Lilac is also fragrant, with white flowers.

Persian Lilac-Ther grow 5 to 6 feet tall, have small foliage and flowers in purple or white.

MOCK ORANGE or SYRINGA - The old-fashioned mock orange. well known to everyone because of its waxy-white, fragrant Howers. It proves a specially good plant for every use, the foliage being large, oval in shape and green. Very valuable for background, screen or grouping, as it makes a height of 6 or more feet.

SNOWBALLS - An old-time farorite with showy white flowers in large ball-shaped clusters in May and June. "The shrub grows to a height of 8 to 12 feet.

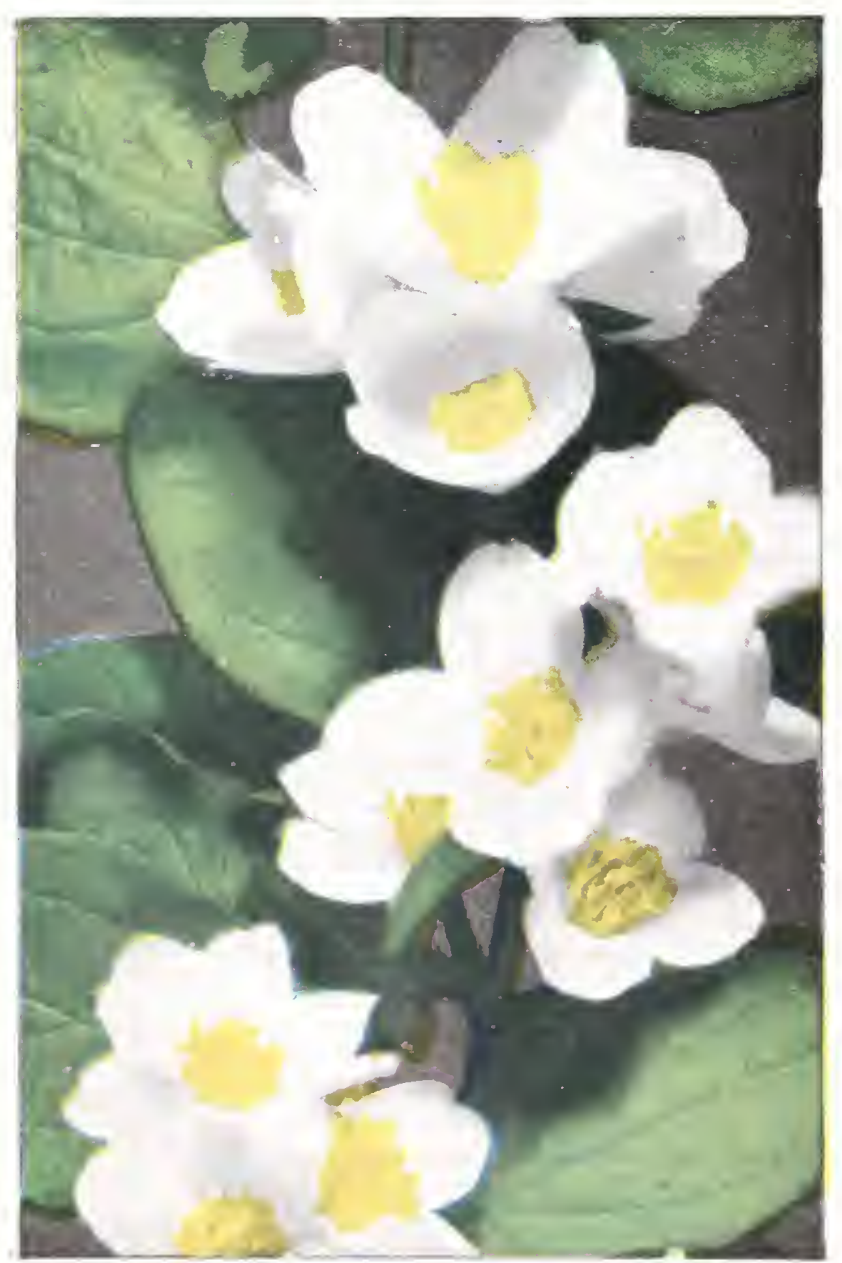

Syringa-Mock Orange
Flowering Shrubs will improve the appearance of your home

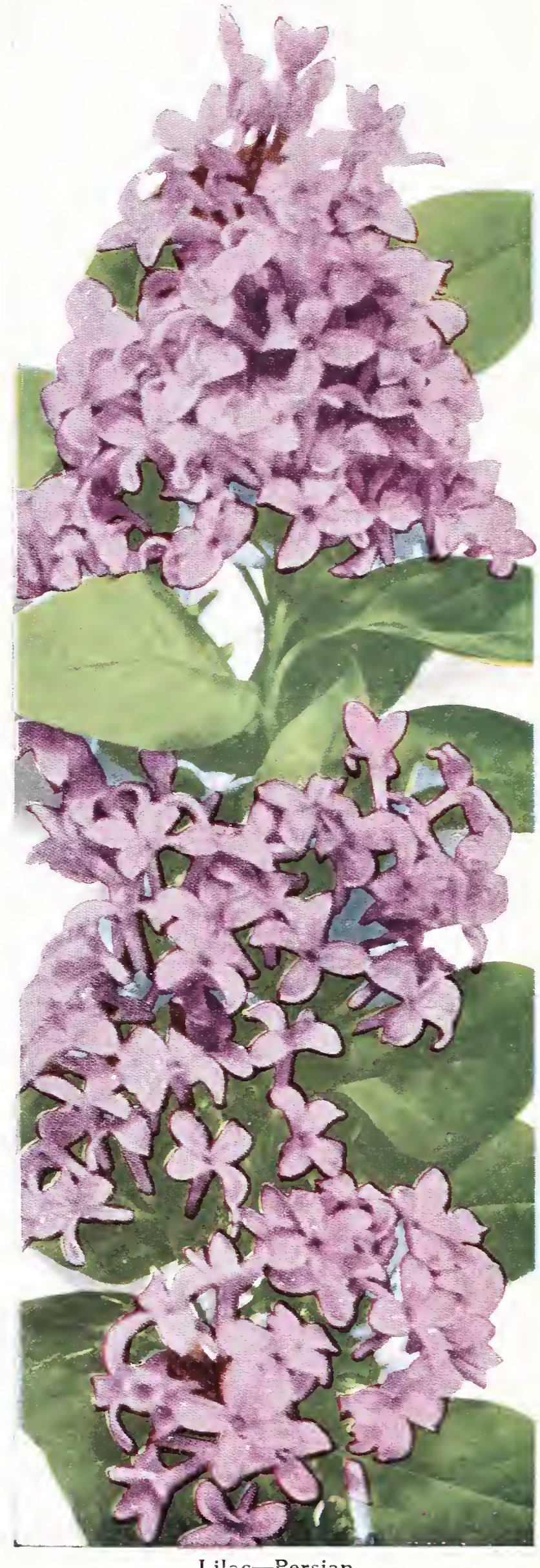

Lilac-Persian

SNOWBERRY - This shrub has small pinkish flowers in July followed by white berries which remain on well into the winter. A very attractive medium sized growing shrub.

\section{The Spireas}

This group of shrubs affords the greatest range in size, habit and color of flowers of any commonly cultivated ornamentals. Spireas are of great beauty when in bloom and of large value for a great variety of decorative purposes.

Spirea Callosa Alba-An upright shrub, becoming 18 inches to 2 feet high. Very profuse bloomer, and continuing in flower throughout the summer. Flowers are pure white, in flat-topped clusters. 


\section{Shrubs-Continued (The Spireas)}

Spirea Anthony Waterer-About two feet high. Bright pink flowers in clusters, blooming in June. A compact low-growing shrub with dense foliage usually deep green with occasional variegated leaves of pink and white on young growth. Flowers are borne in full, flat clusters on erect stems. If these are cut a way when they fade the shrub will usually bloom intermittently during the summer. Very valuable for edging in front of shrubbery or sometimes used as a dwarf hedge.

Spirea Billardi-Tall, enect shrub with canes terminated by feathery plumes, 5 to 8 inches long, of dainty pink color.

Spirea Douglass-Deep pink, blooming in July. Slightly taller and a little more branched than Spirea Billardi. Terminals of each branch crowned with flower spike six inches long.

Spirea Prunifolia-White, blooming in April and May. This is an old-fashioned variety, flowers borne close to the slender erect branches in the spring befcre foliage appears. The individua! flowers resemble miniature roses and are usually borne in great profusion. The foliage is shiny dark green and in the fall turns bright red.

Spirea Reevesiana-White, blooming in May. This is one of the best of the Spirea group. White flowers, borne along the stem just as the foliage appears, make a most attractive bush wherever used. The foliage appears early and remains exceptionally late in the fall. In labit it is very graceful and can be used in foundations where plants of 4 to 5 feet in height are desired.

Spirea Thunbergi-This extra early flowering species is the pride of the Southland. It is spreading in growth with arching slender branches that are a perfect mass of minute flowers followed with exceptionally delicate green foliage. For edging purposes we recommend it highly.

Spirea Van Houttei-This is the most useful of the hardy shrubs. It has grown so popular that we sell more of it than all other varieties combined. The flowers are in flat clusters usually an inch or more across, produced on spreading, pendulant branches of ten drooping to the ground. In full bloom they are a mass of white and never fail to attract attention. The foliage is attractive green, which it retains late in the year. This variety can be used in any location for hedging, grouping and mass effect. There is nothing superior in our catalogue. When in doubt or at a loss as to what to use, plant our Spirea Van Houttei.

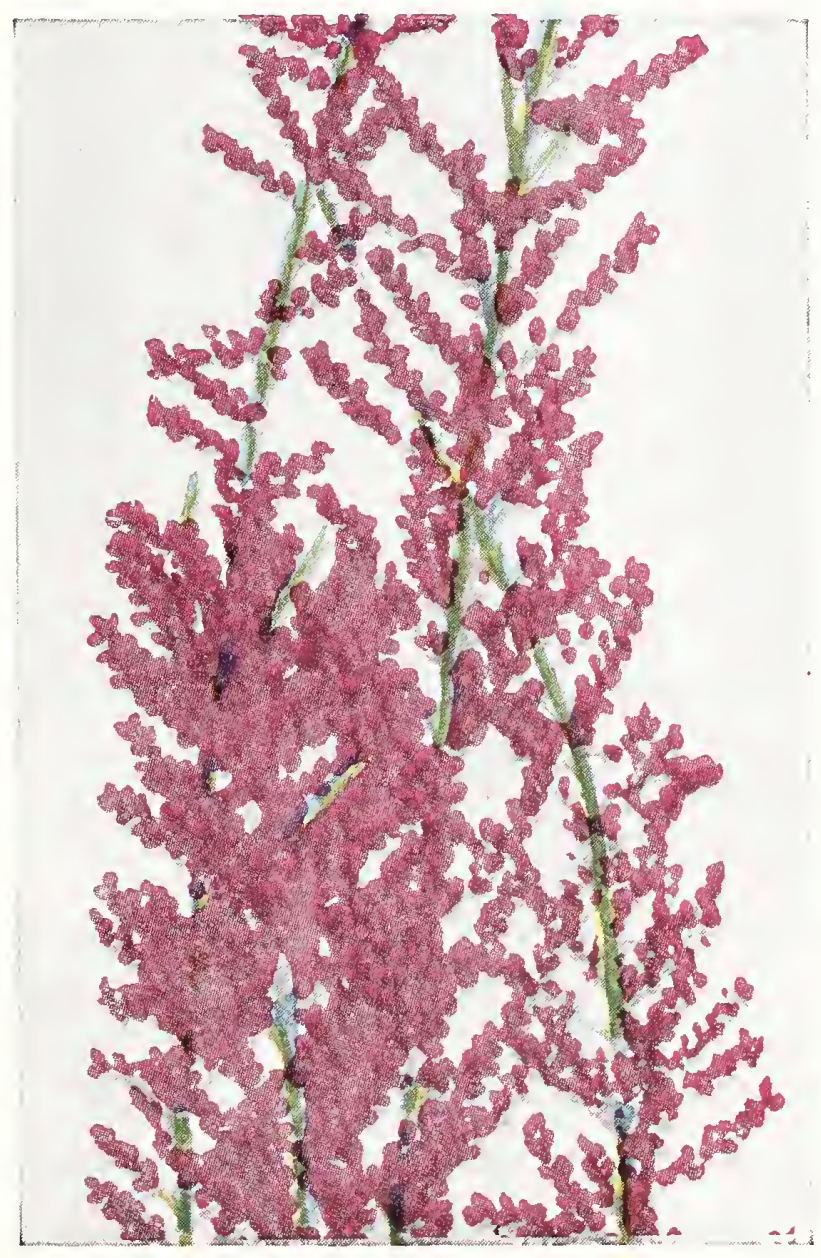

Tamarix
Our Shrubs -large and well developed -will bloom this summer

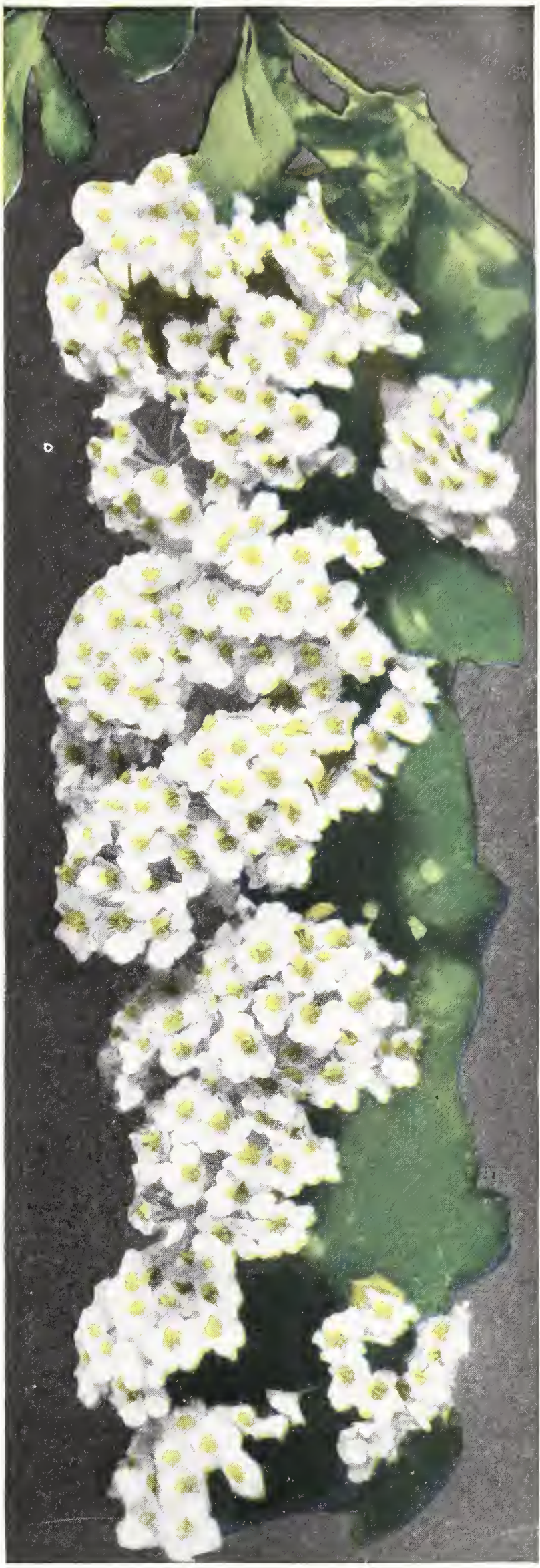

Spirea-Van Houttei

TAMARIX - The Tamarisks are hardy shrubs of strong growth foliage light and feathery, their flowers delicate and fringing, usually in some light shade or red or pink. Will grow anywhere.

WEIGELA - Beautiful shrubs that bloom in June and July. The flowers are produced in so great profusion as almost entirely to hide the foliage. They are very desirable for the border or for grouping and also as specimen plants for the lawn.

Weigela Candida-Flowers are pure white produced in June and continue to bloom nearly all summer.

Weigela Eva Rathke-Flowers a brilliant crimson.

Weigela Rosea-An elegant variety with fine rose-colored flowers appearing in June. One of the most popular and showy shrubs. Has numerous spreading branches that are covered with a wealth of blcom. 


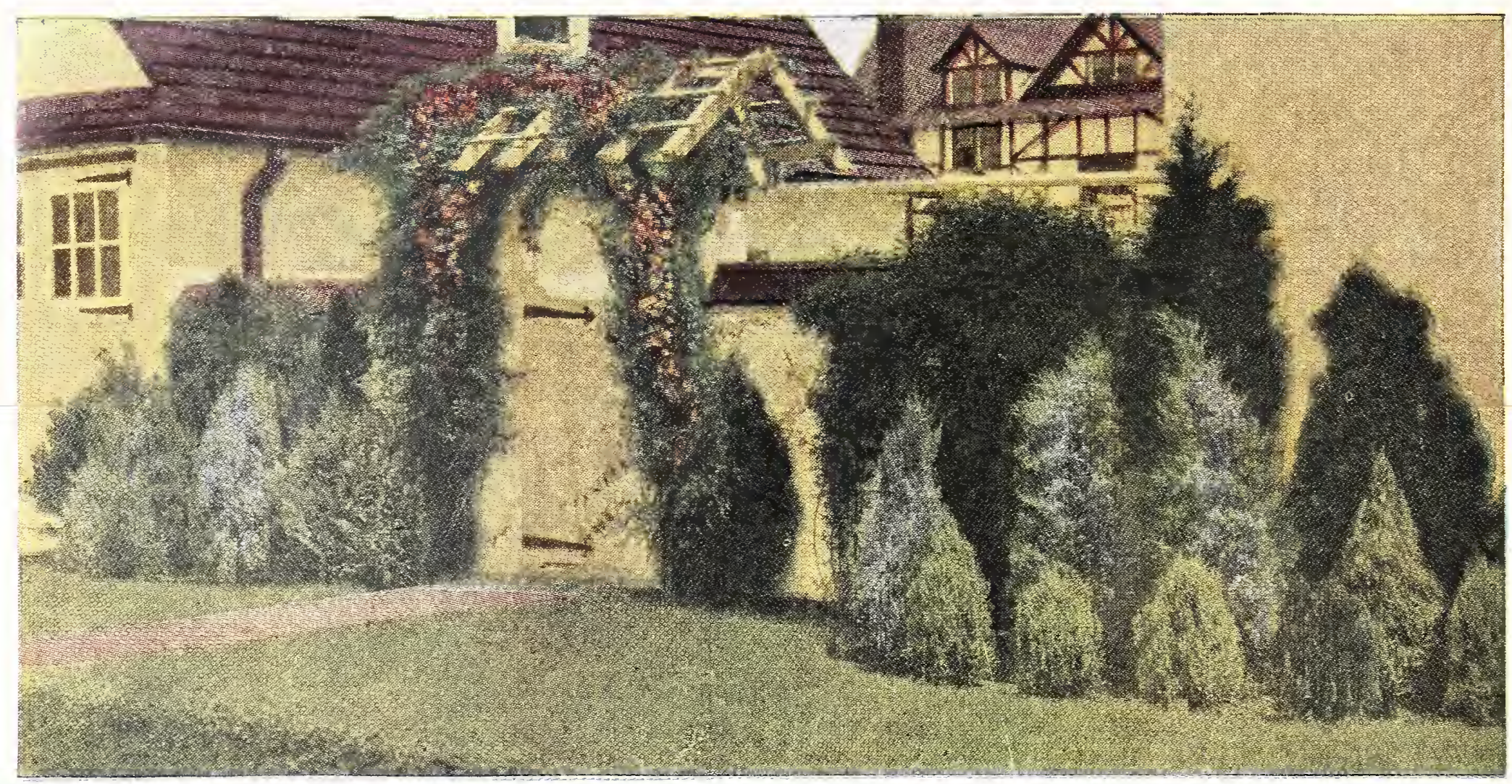

A planting of various Evergreens is distinctly beautiful

\section{Evergreens}

Strikingly ornamental in either its tall stately groups or in the dwarf varieties for lawn decoration or land=cape work. The smaller varieties when used for foundation planting seem to blend the house and lawn into a pleasing suggestion of perma nency and well-being. Tastef ully ar ranged they unquestionably enhance realty values.

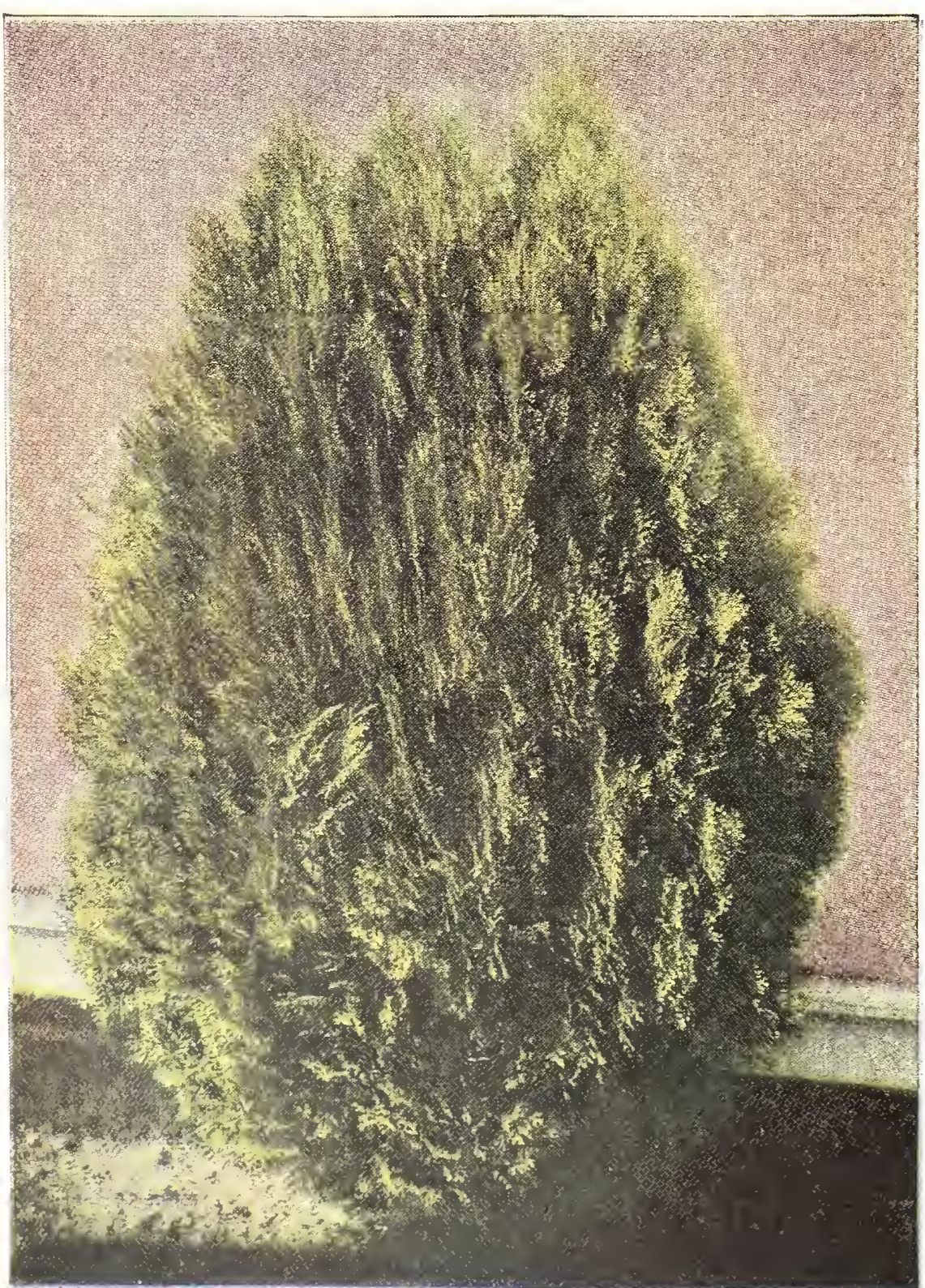

Berckman's Golden Arbor Vitae

Evergreens may be used as individual specimens, or in groups on the lawn, for street planting and also for massing. The proper use for the finer evergreens as foundation plantings around the house, will produce the very finest results and this is the class of work that is certain to become very popular. Already many people have taken out their old shrubs that have grown too large and ragged, and in their places are setting the many-colored Evergreens. With a proper use of evergreens the beds will look pretty the year around, and especially is this appreciated in winter when everything else looks bleak and bare.

IVe are listing here only a part of our Evergreens. We find that these varieties do best for Kansas and Oklahoma. We grow other varieties and upon request we will be glad to write you of them and give prices. Our Evergreens are specimen trees, compact in their habits and very attractive. Each tree is dug with a large ball of mother earth of its roots and this ball is then burlapped, holding the dirt firmly about the roots. As the roots have not been disturbed, the trees will be sure to live after transplanting. Our Evergreens have been many times transplanted in our nursery fields, giving the tree a vigorous, fibrous root srstem.

\section{Arbor Vitae Berckman's Golden}

This is without a doubt the showiest of al the Arbor Vitae family. The color is an unusually bright green, turning to a golden-yellow in the winter months, and is striking in appearance. Our Berckman's Golden are dwarf, very seldom growing over four feet in height, are compact and dense, never needing any pruning as they make and hold their own shape. Does especially well and should be in every planting. Berckman's Golden require sunshine. 


\section{Evergreens-Continued}

\section{Arbor Vitae (Chinese Compact)}

Dense, compact, upright grower. Very excellent for yard plantings. Absolutely hardy, requiring very little attention.

\section{Arbor Vitae, Oriental (Chinese)}

This has the typical pressed foliage of the Arbor Vitae family, but is inclined to branch erect forming in folds about the stems of the plant. It is different from the other varieties in character of growth and appearance. It grows very rapidly and can be used where mass effect is wanted, as a specimen or in a hedge. It shears especially well and it is often necessary to prune it to make it real compact as it is inclined to grow open.

\section{Arbor Vitae (Pyramidalis)}

This is strikingly attractive, heing perfectly pyramidal in shape, spreading very little at its base and retaining the shape without shearing. The color is deep rich green and like all Arbor Vitaes is easy to transplant. For corners, in front of pillars, center or background of group plantings there is hardly an evergreen of the dwarf variety that is quite so popular.

\section{Arbor Vitae, Bakers}

A tall, compact, pyramidal type. The foliage is bright green and the inside never turns brown. It is of beautiful form and color. Transplants easily, grows rapidly, and never outgrows its beauty. In fact, the longer it grows the prettier it gets.

\section{Juniper (Savin)}

Prostrate spreading branches with somber green foliage. Hardy and well adapted for hillsides, etc.

\section{Juniper, Chinensis (Chinese Juniper)}

A small tree of columnar form with silvery-green foliage. It is entirely hardy, retaining its dense and graceful habit well under any decent treatment.

\section{Juniper, Stricta}

Perfectly round, very dense in growth, with many short branches covered with soft dark green foliage. Excellent for planting among perennials, in rock-gardens, and in situations requiring Evergreens that will remain small. The trees we offer you are perfect specimens.

\section{Juniper, Virginiana (Red Cedar)}

This well-known native variety grows to a tall, stately tree, with dark green foliage. It is excellent for naturalizing, but may also be kept sheared to any desired height or shape.

Juniper Virginiana

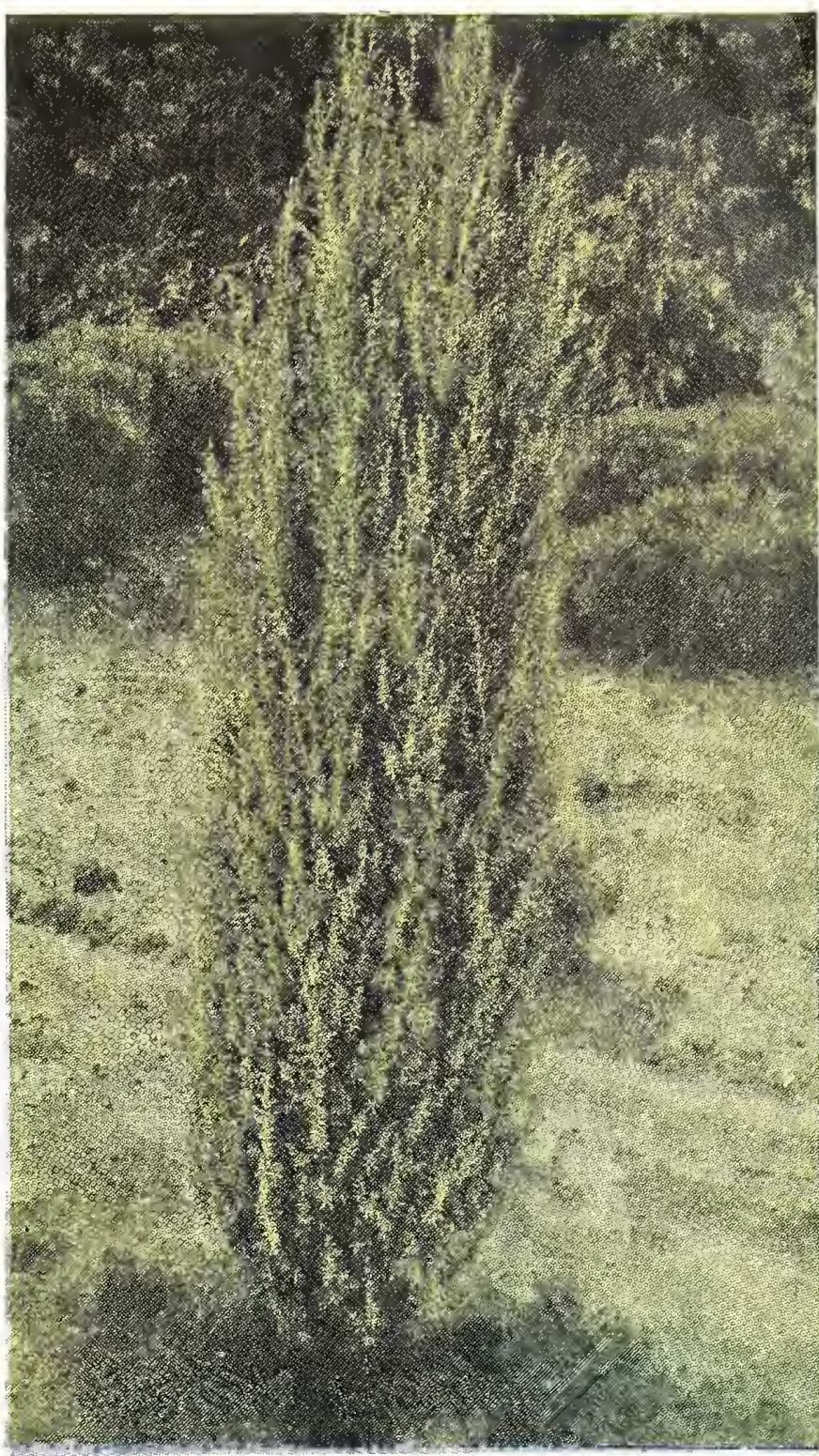

\section{An Invitation}

The American people are rapidly learning to appreciate beautiful home surroundings. A well-landscaped dwelling sends out a perpetual smile, winter and summer alike, to your family and every passing stranger, and radiates a quiet refinement. If the grounds surrounding your house are extensive, beautiful effects can be produced by planting shade trees, shrubs, vines and flowers according to some prearranged plan. If your grounds are small, one or two trees anr a few shrubs, properly set, can be used with even more wonderful effect. A simple vine trained over the porch is very effective and gives comfort and satisfaction to your family and the passerby. Let me emphasize the fact that you should buy none but the best. It is not the quantity, but the quality that counts. The best stock, properly grown by our reliable nurserymen, who have given their thought to caref ul propagation and used the greatest care in the selection of the best varieties, is always the cheapest in the end. Being growers and selling thus direct to you, we make you a price based on the cost of production, often at a great saving. Come and see our stock growing. Select it yourself. You will be dealing with a realiable firm, not with some jobber of material, who buys his plants here and there, sometimes using inferior stock to complete a job. 


\section{Plants for Ornamental Fences}

When in doubt as to the kind of Flowering Shrubs to use, plant Spirea Van Houttei - very beautiful, hardy, and adapted everywhere.
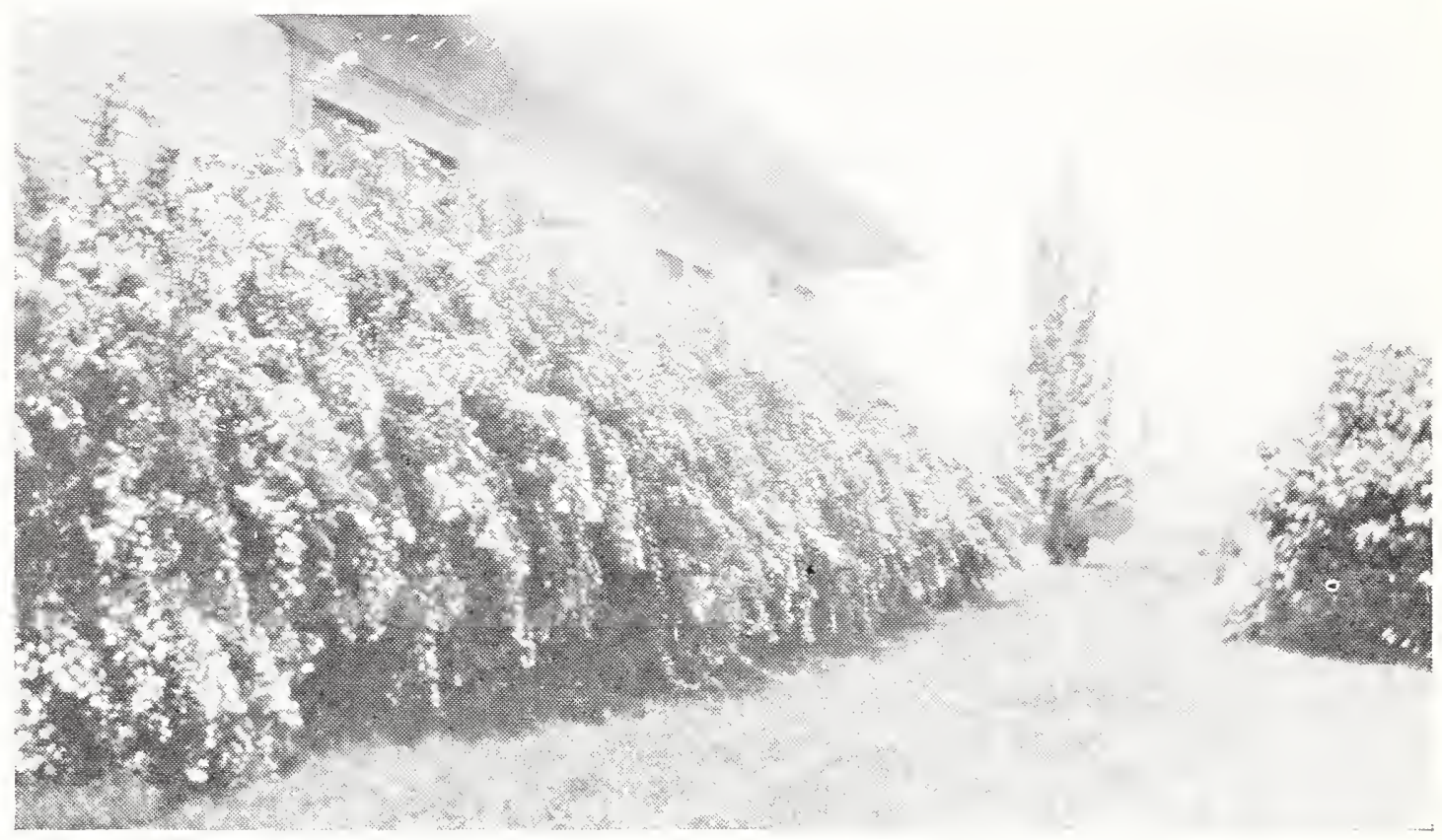

An Ornamental Hedge of Spirea Van Houttei

There is no better line of improvement that can be put upon a property than a well-kept hedge. A living fenceone made from growing plants, attractive with their green leaves, formal trained or arched branches, colored foliage or bright berries - is surely more pleasing than the still, rigid, mechanical effect obtained by the similar use of wood or metal. A variety of plants may be used, including not only the privets, which we describe below, but flowering shrubs like Altheas, Spireas, Fragrant Bush Honeysuckles and sometimes, evergreens.

To be a success, a hedge must be intelligently set and properly cared for. Select the kind of plant that suits the position and purpose. Start with rigorous plants of an even grade. Dig a trench, fertilized with well-rotted ma nure, and set the plants evenly and tread the soil firmly around them. After ther are planted, cut down to one level. If you use prirets, cut two-thirds of the top back and set 10 to 12 inches apart.

AMOOR RIVER PRIVET-For neatly-trimmed formal hedges about the lawn, no shrubs are more popular than the privets. The varieties we grow are ideal fence plants. They withstand frequent shearing and the more often they are trimmed, the better they look. Every lawn should have its boundaries marked by a row of our Privets, neatly trimmed. Ideal for screening objectionable views, as when left untrimmed they become as much as 10 feet tall, very dense, and with excellent foliage. Our Amoor River Privet is very hardy, with glossy green foliage and holds its color almost the entire year. It will stand shearing to any extent.

CALIFORNIA PRIVET - This most popular hedge plant is of a free, upright growth, with glossy dark green lea ves. Nearly evergreen in the Southern states. Also can be used for single specimens for terrace, hall, or porch decoration. After setting prune to within $t$ to 6 inches of the ground, also prune severely the next one or two seasons after planting to maintain the height and shape desired. California Privet has a tendency to winter-kill north of Oklahoma.

\section{Tom Rogers' Residence Winfield. Kansas}

Our Landscape Department will gladly outline a planting along similar lines for you. 


\section{Ornamental}

\section{Shade Trees}

CATALPA BUNGEII-A Chinese variety; very remarkable for its dense, round, umbrella-like head. Makes a beautiful tree when grafted and budded on a high stem. Fine for formal effects and planting at entrances.

CATALPA SPECIOSA-Hardy Catalpa. An effective tropical-looking lawn tree with very broad, large, leaves and fragrant, purplish-white blossoms of pyramidal clusters oftèn a foot long. There are few trees that have been more extensively planted for commercial plantation in the Middle West and the Eastern states. It is hardy, grows rapidly on prairies, resist drouth remarkably well and has hardly any insect enemies. As a post timber it ranks with the Black Locust and Osage. Experiments have left no doubt as to its resistancy to decay. Without doubt, for fencepost wood it has no equal, and in view of the fact that it can be grown so easily, it ought not to require much argument to cause farmers to plant Catalpa wherever it will grow.

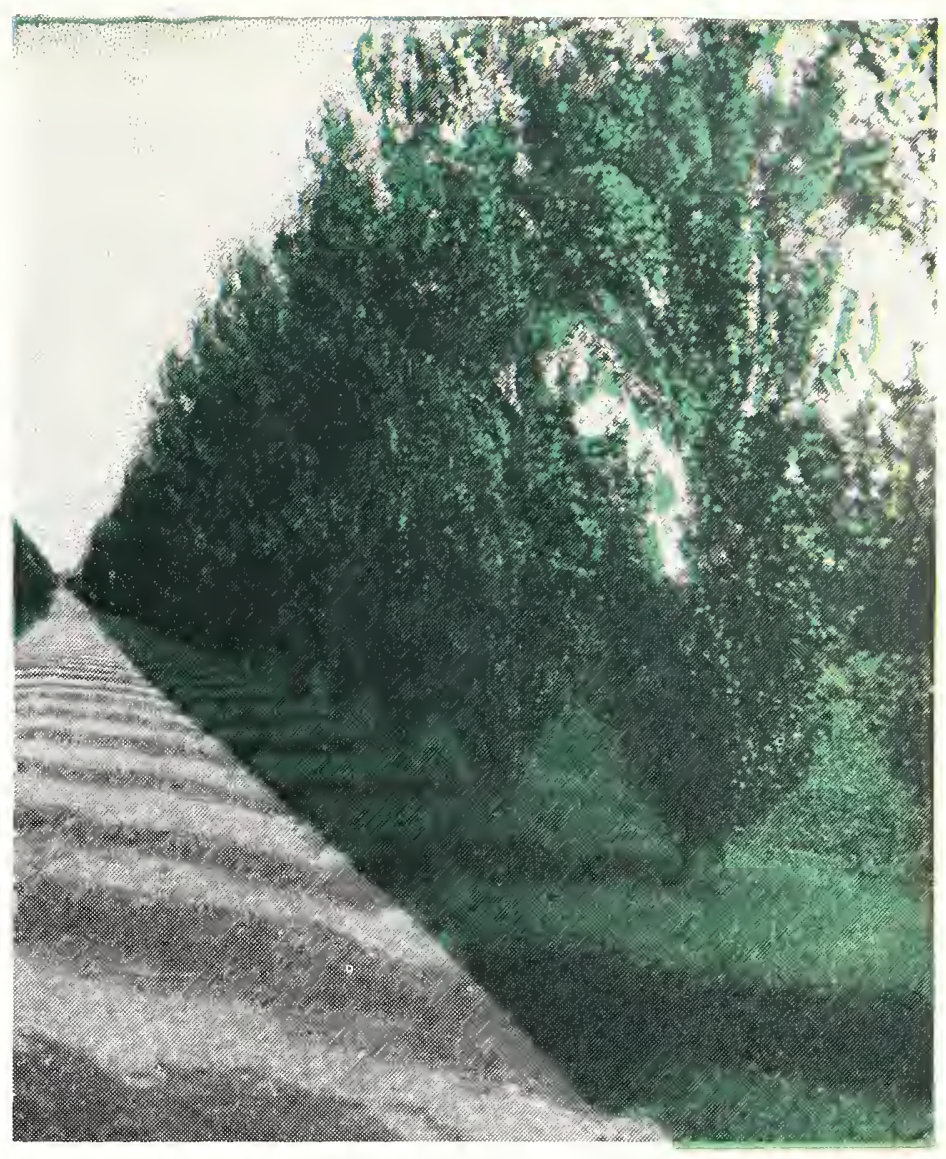

Lombardy Poplars

ELM (American or White) - The large-leaved, rapid-growing variety. It attains a great size and age, and the longer it grows the handsomer it becomes. It grows everywhere, in all locations and soils.

BLACK LOCUST-Also called Yellow Locust.-A large native tree of rapid growth, valuable for shade as well as quite orna mental. The yellowish-white flowers are in long, pendulous racemes and appear in June. Wood is very valuable for posts, growing quicker to a given size than a ny other hardwood tree. The timber is of very best quality and for posts outlasts, with a few exceptions, all other sorts. The Forestry Division of the Agricultural Depart ment at Washington recommends the Black Locust for timber plantation for Oklahoma, Texas, New Mexico, Kansas, Nebraska and California.

HONEY LOCUST - This is an ornamental native tree of more than ordinary value. Its branches are spreading, forming a broad rather loose head. The branches and trunk are covered with strong thorns. It is of rapid growth, stands pruning well and is often used for a hedge; its thorns make it almost impenetrable. We do not know of a better tree for western Kansas. Is found growing wild along creeks and streams most everywhere in Nebraska and Kansas.

POPLAR (Lombardy) - This grows to an immense height, and is remarkable for its columnar growth. In landscape work breaks the monotony of the lower, round-topped trees. One of the characteristic trees of Lombardy and other parts of Italy.

POPLAR (Carolina)-A vigorous, healthy native tree of rapid growth, pyramid in form, with large, glossy leaves; valuable for park or street planting.

MAPLE (Soft or Silver) - A hardy, rapid growing native tree of large size, valuable for producing a quick shade. Excellent for street planting. Our stock of these is very large in al! sizes.

MAPLE (Hard) T.-A very popular American tree, and for its stately form and fine foliage justly ranked a mong the very best, both for lawn and avenue.

SYCAMORE or PLANE - The Sycamore is probably the hardiest of all street trees for our larger cities. It can stand more abuse than any other tree we know of, is not affected with many of the injurious insect pests that inf ect other varieties of trees, it can stand the smoke and gas better than can most other ornamental street trees.

RUSSIAN MULBERRY - Tree very hardy; poultry raisers should plant this tree near the poultry house or yard, as they will make a nice shade for the yard and the berries are much relished by the fowls and are very healthy. It is also well to plant a few mulberry trees near your cherry orchard, as the birds prefer the mulberry a nd will not take your cherries. The wood is very valuable for fence posts, lasting for 20 years in the ground. Also makes a very attractive hedge if kept well pruned.

\section{Forest Tree Seedlings}

We recommended the planting of Forest Tree Seedlings very strongly to our customers, particularly those who live in the wind-swept portions of our state. Plant Forest Tree Seedlings and protect your buildings, stock and crops. They are very excellent to break the strong north winds, provide shade for your stock in the summer and give you material for your own posts. Our prices are astonishingly low and you can not afford to be without the protection that Forest Tree Seedlings will give you within a few short years.

We grow the following varieties: Catalpa Speciosa, Black Locust, Honey Locust, Russian Mulberry, Elm and Maple. (See description under shade trees.) We also have Osage Orange, too well known to need describing here.

Our friend, Mr. C. E. Haas, County Clerk of Tillman County, Oklahoma, writes on November $23 \mathrm{rd}$ : "Mr. and Mrs. J.E. Hines asked me to express to you their appreciation for the nice Carolina Poplar they received Novembir 2 Ist. The tree was much finer than they expected." 


\section{Hardy Herbaceous Perennials}

Perennials should be found in every garden. They are far superior as cut-flowers to annuals; once planted, requiring very little attention. The are always glad to assist you in making selections for various purposes. By Hardy Perennials we mean such plants as remain permanently in the ground. The foliage dies down each autumn, but comes again with the same rigor the following spring. There is such a variety in color and times of blooming a mong them that continuous flowering can be assured from early spring to late fall. The following list of perfectly hardy rarieties has been prepared by us with special care as to range of colors and different styles of growth:

PHLOX - This hardy perennial, that has been cherished in mothers' gardens for generations, is again fast gaining in popularity, and in its new varieties of shades never fails to arouse admiration, either in small clusters or massed in heary borders. Four or five shades grown in conjunction give a very effective result of color blending. The prof use flowers remain nearly all summer. If the early clusters of flowers are cut, a second set, fully as beautiful, will be put forth. Order at least a dozen of our Phlox, and we will give you a selection of the choicest varieties with a rainbow of colors.

COLUMBINES - Blooming in the late spring and through the early summer months, preferring slightly shade positions, though it does well in the sun. The flowers are borne on slender stems and mostly long-spurred-coming in the many shades they do, prove very valuable in any garden.

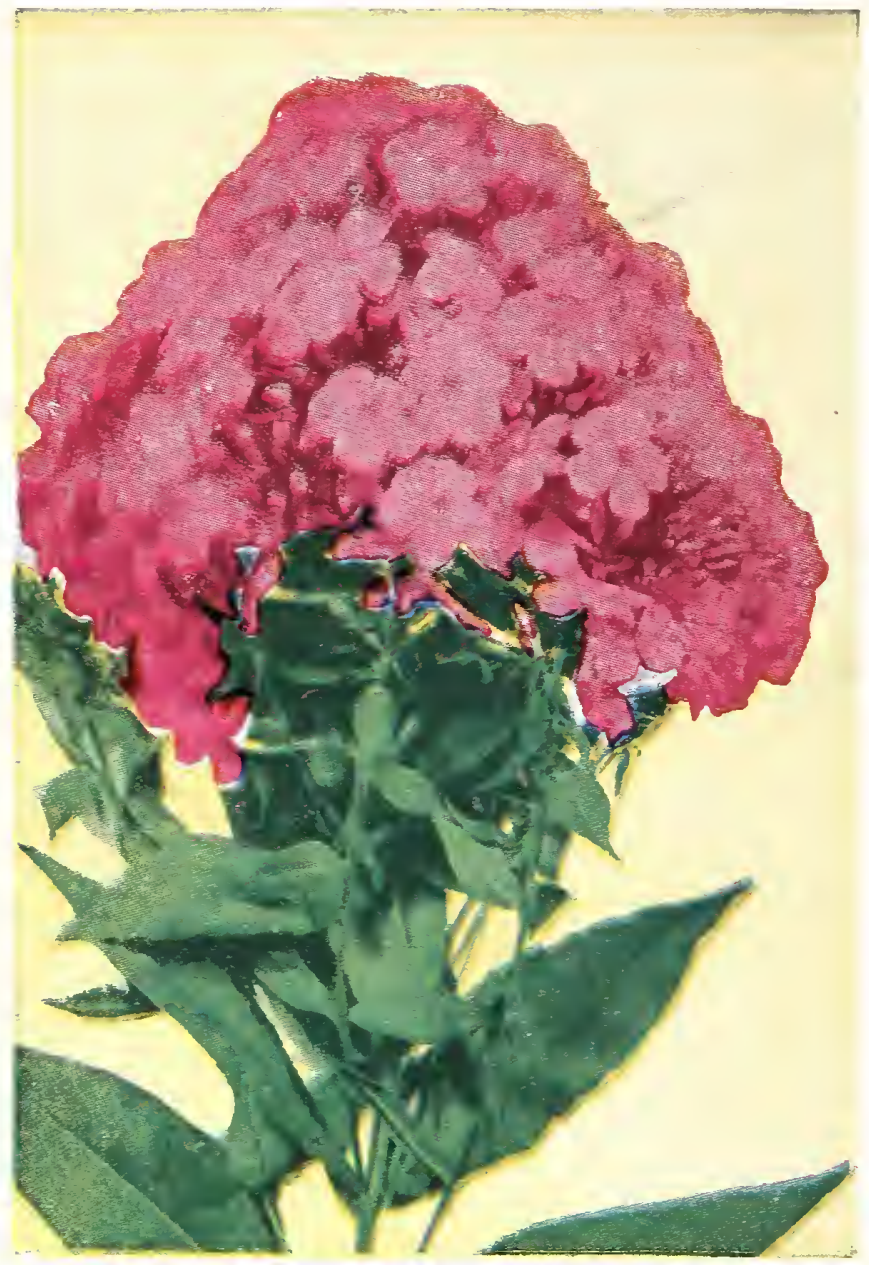

$\mathrm{Phlox}$

HARDY ASTERS are unrivaled for their varying forms and bright colcrs in the perennial border during the autumn months. The wonderful shades of colors lend themselves well for cutting and decorative purposes.

CHRYSANTHEMUMS are hardy and most attractive in September and October. The flowers are rery attractive, borne in large quantities. We have white, pink, red and yellow

COREOPSIS is one of the most showy of hardy plants with a daisy-like flower, rich, shining yellow. A continuous bloomer from June to September.

SHASTA DAISY - Thite flowers 3 to $t$ inches in diameter, borne on long stems. The blossoms when cut remain fresh and in good condition for ten days or more. Very hardy perennial. Blooms from several months.

GAILLARDIA - Large crimson and gold flowers. Hardy, thriving in any location. Deserves a more prominent place than it is accorded.

HARDY AGERATUM - A pretty, hardy plant with light purple flowers, blooming from August until frost.

HIBISCUS (Mallow Marvels)-Larger and more brilliant than the old forms. Plants frequently grow five feet during July and August, producing blooms 8 to 10 inches across, especially if given water. We can furnish in white, pink and red.

HOLLYHOCKS are well known to everyone. With their long spikes of multi-colored flowers, borne in profusion as they are, there is no wonder they are so largely used. Blooming in June, so absolutely hardy they will take care of themselves.

IRIS (German) - One of the most beautiful and showy of the early-flowering plants, deliciously fragrant and fine for cutting. In beauty they rival the orchid. Should be in every garden.

IRIS (Japan)-The flowers differ from the above in being broad and flat. They exhibit the most beautiful delicate shades. Perfectly hardy and flower in great profusion in June and July.

PERENNIAL SWEET PEA - One of the best and most desirable flowering, hardy, climbing plants, growing to a height of 8 to 10 feet and producing clusters of large flowers the entire summer. Fine for cutting, lasting well.

ORIENTAL POPPY - Vivid red, blooming with Peonies, and the joy and admiration of everyone. We adrise fall planting only.

LILY OF THE VALLEY is often neglected and planted in some poor out-of-the-way corner, but this popular and fragrant plant, if we!l treated, will show the effect by increased size, number and vigor of the flowers. It is especially suited for outdoor plänting, which should be done before the end of April.

PLATYCODON (Bellflower)-This comes in blue and white, blossoming in July. An attractive flower, often three inches across.

SWEET WILLIAM is a fine plant which produces great masses of bloom of extremely rich and varied colors. The flowers a re lasting and fine for cutting.

VERONICA - A family containing some of the most beautiful subjects for the hardy garden and rockery. Given a rich, well drained soil in an open situation in full sun, thes will thrive in an a mazing manner.

\section{Bulbs}

CANNAS- Vigorous, furnishing a wide range of color; fine foliage of large proportion, almost entirely concealing the ground: flower trusses are large and free. We have pink, red and yellow shades.

GLADIOLUS-A nice assortment. Should be planted after the middle of Aprit.

PEONIES may be planted either in the fall or early spring. We have a nice lot in separate colors and named varieties. DAHLIAS seem to do better north of us than they do here. We have a nice selection of bulbs.

FALL BULBS-Early next fall we will have a nice lot of Tulips, which we are importing from Holland. Write for descriptive list. 


\section{Asparagus}

Asparagus is another delicacy that comes early from the vegetable garden. Like all very early vegetables, it costs quite a good deal; and yet a bed of Asparagus in your own garden will keep your table supplied and last for years. We handle two-year crown plants, which will throw up sprouts for use the first year.

Asparagus is of comparatively easy culture, once a bed is established. It should, with moderate care, produce upward for twenty years. It is very adaptable to variable soil conditions, a sandy loam preferred. The bed must be well drained, as it will not thrive under excess moisture. Prepare soil by thorough sub-soiling and deep plowing. Go down at least 15 inches. Dig trenches a foot deep, $4 \frac{1}{2}$ feet apart, earth thoroughly loosened and liberally dressed with well decomposed stable manure, and a layer of at least two inches of dirt over this. This allows 8 inches for the planting of the Asparagus root. Very often the trench is left open, with only about two inches of soil over the roots, or crowns, fresh soil being applied as the roots develop, until, by the close of the first season, the surface is practically level. We recommend the roots be set 20 inches apart in the row. Thus planted, approximately 5,000 roots are required for an acre.

Any information that you require as to planting distances, best methods of planting, what and where to plant, will be gladly answered if you will direct an inquiry to this office. We do not claim to know everything, but we will give you our honest opinion to the best of our ability.

"I would like to tell you our Cannas purchased from you in the spring were lovely. Numbers of people commented on the appearance of the bed at the City building. Very sincerely yours, ANNA M. KEECH.

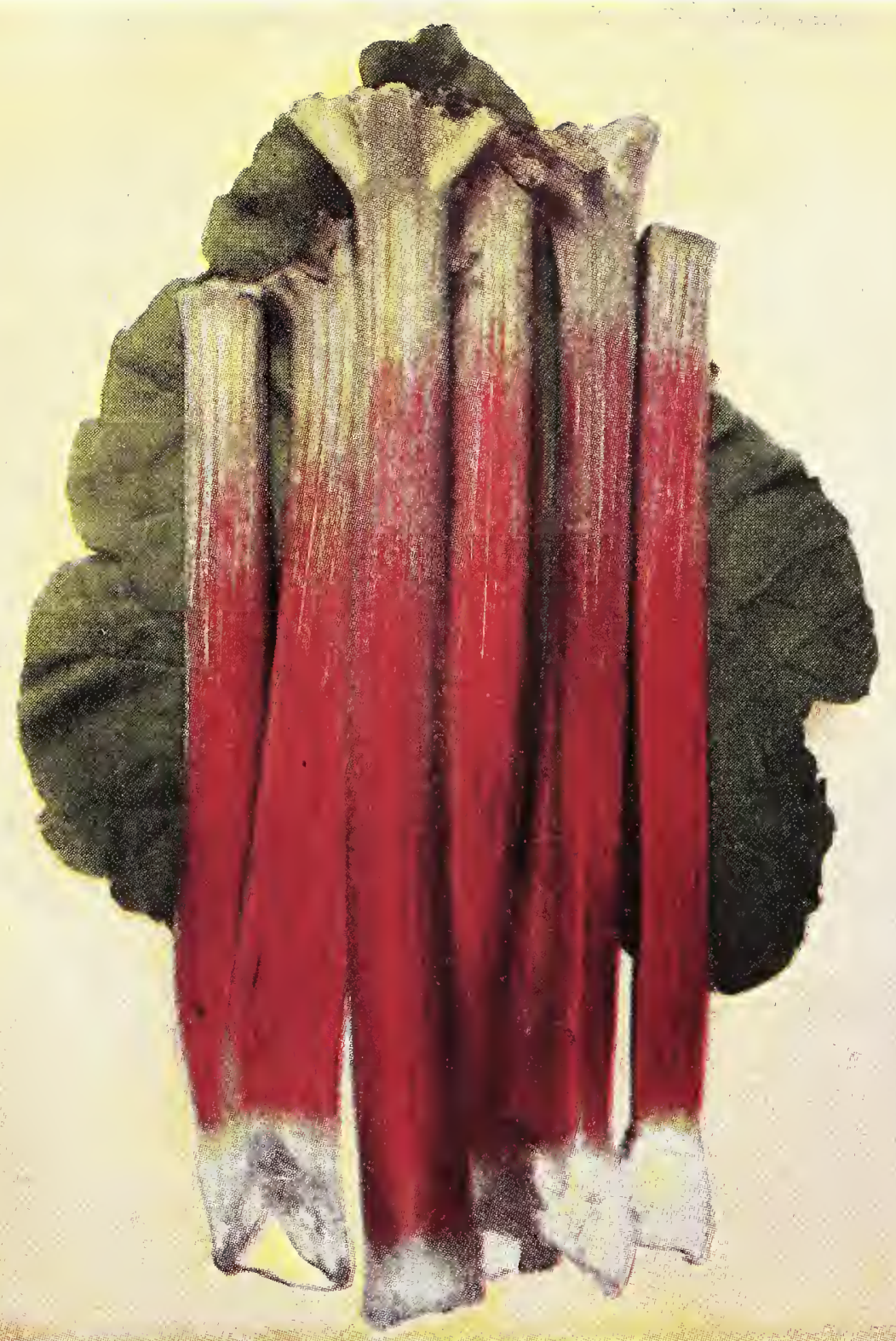

Rogers' Giant Wine-Red Rhubarb

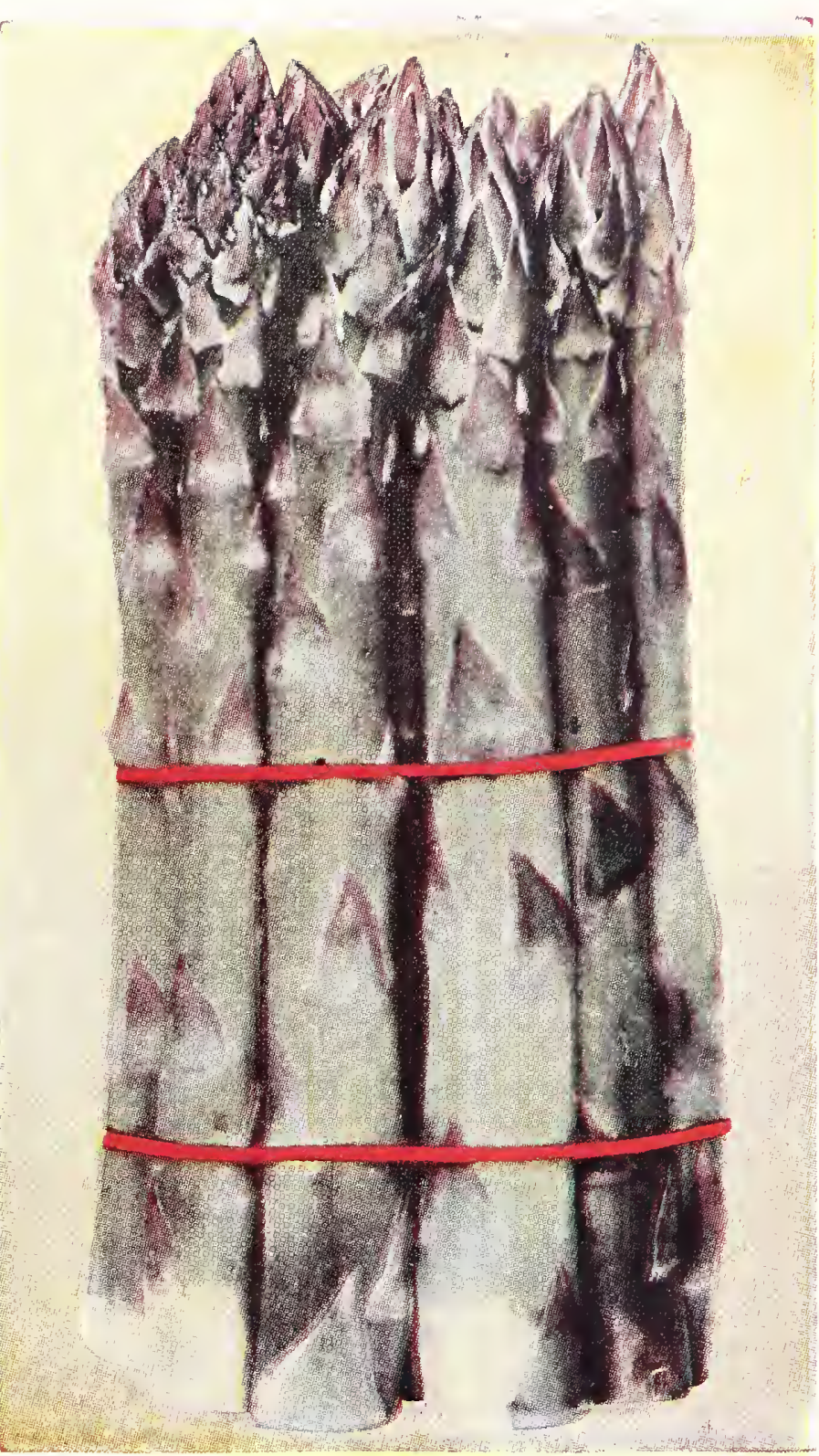

Asparagus

\section{Rogers Giant Wine-Red Rhubarb}

Rhubarb is really a part of the vegetable gardenand a very important part. It is the first thing out of the garden each spring; in fact, Rhubarb "sauce" and pies are always taken as assurance that spring has come to stay. Rhubarb is a diet needed in the spring; health-giving and refreshing and delightful to the taste.

GIANT WINE RED-This variety is the kind that is proving so successful and profitable to commercial gardeners. We have been growing this wonderful variety over a long period of years and thoroughly recommend it to our customers. Rogers' Giant Wine-Red will not "seed" as it is propagated from divisioned plants. Every stalk is alike. All big and crimison-red in color. Very sweet and tender. A home garden should have at least two dozen plants. Do not pull Rhubarb the first year. There is danger of pulling the roots loose from the soil.

MATT'S LINNEAUS (Seedling Rhubarb) Grown from seed and is sa me as that being offered-you by many nurseries. We don't like to sell you seedling Rhubarb but if you insist upon wanting something cheap and inferior to Rogers' Giant Wine-Red, we can take care of your order and at one-half the price of our select stock. Seedling Rhurbarb is not worth one-half the price stock. Seet Giant Wine-Red Rhubarb, but that price i of our select Giant Wine-Red Rhubarb, but that price is so much cheaper than any other nurseries we hesitate to
make it any lower. Pay a little more money and get the best. 


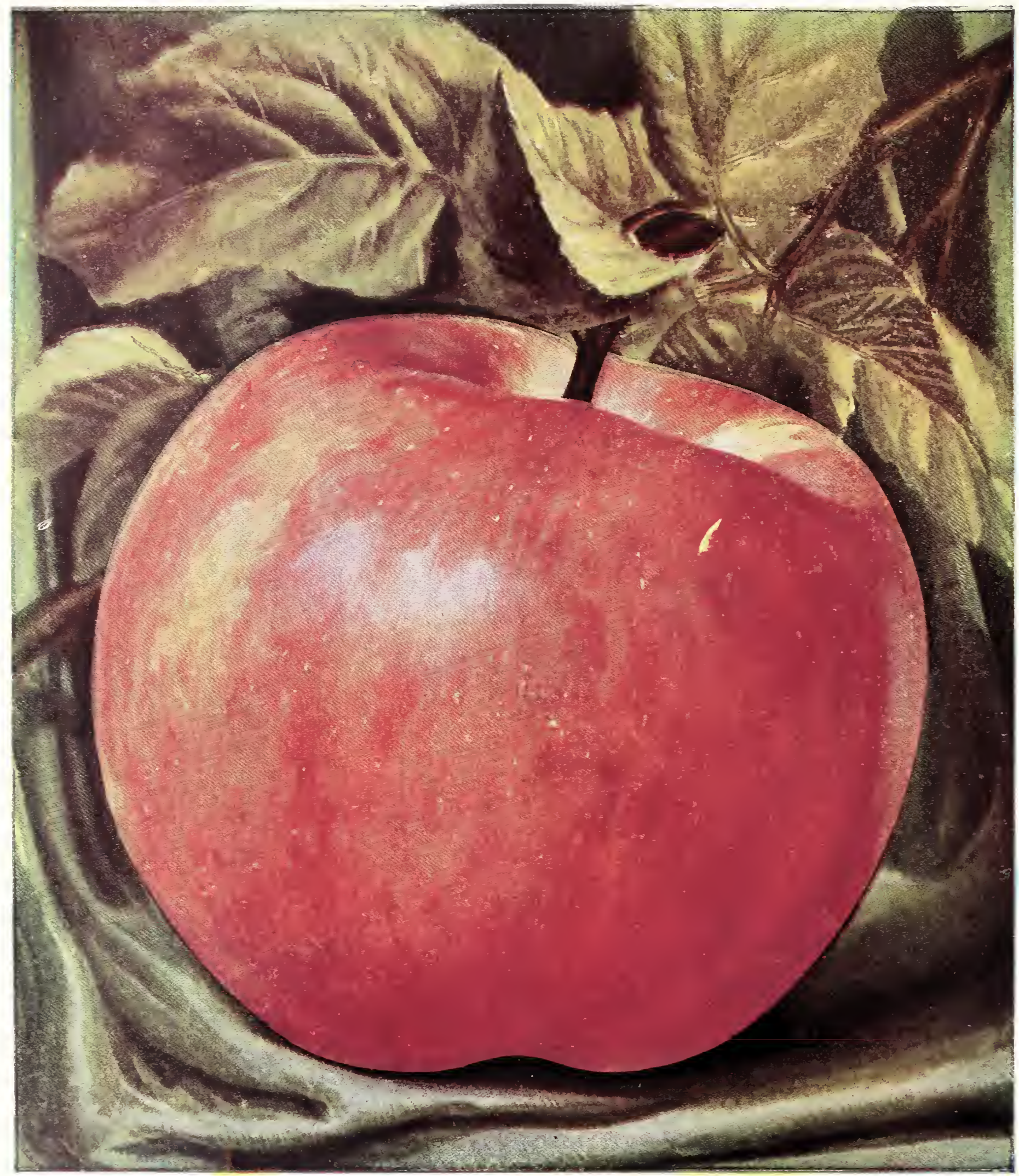

WINESAP APPLE--ONE OF THE BEST - See Page 6

The Winfield Nurseries, Winfield, Kansas Ouned and Operated by Thos. Rogers \& Sons

View of Our Storage and Packing Houses 